\title{
IMF Publication
}

\section{Initiative for Heavily Indebted Poor Countries - Status of Implementation}




\title{
INTERNATIONAL MONETARY FUND AND \\ INTERNATIONAL DEVELOPMENT ASSOCIATION
}

\section{Heavily Indebted Poor Countries (HIPC) Initiative—Status of Implementation}

\author{
Prepared by the Staffs of the IMF and World Bank \\ Approved by Timothy Geithner and Gobind Nankani
}

September 12, 2003

Contents Page

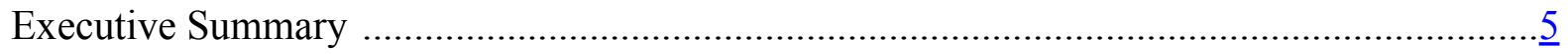

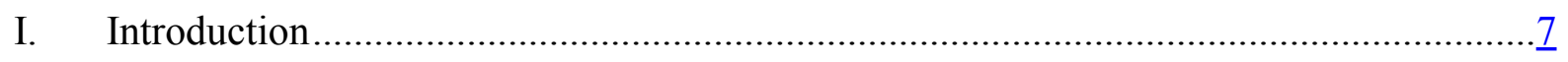

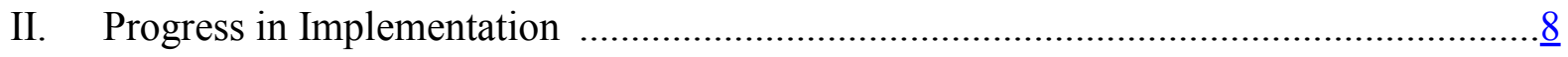

A. Reduction in Debt Stocks and Debt Service .................................................... 8

B Resource Flows to HIPCs ……………………….....................................12

C. Implementation and Cost Update...................................................................14

III. Challenges in Reaching Completion Points and Decision Points................................... 15

A. Challenges in Reaching Completion Points....................................................16

Achieving Macroeconomic Stability …………………………………...

Implementing Poverty Reduction Strategies .............................................

Satisfying Social and Structural Completion Point Triggers ..........................25

B. Challenges in Reaching Decision Points .............................................................

IV. Observations on Governance and Debt Sustainability ................................................

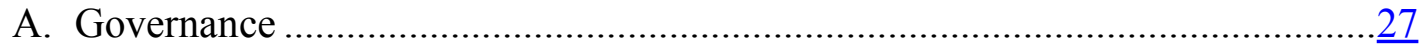

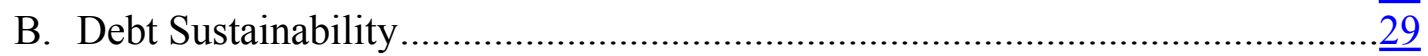

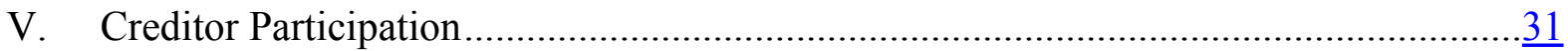

A. Multilateral Creditors: Costs, Commitments and Delivery …………………......

B. Official Bilateral Creditors: Costs, Commitments and Delivery ……………......

C. Commercial Creditors and Creditor Litigation .....................................................

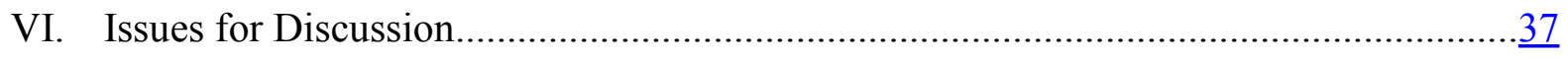




\section{Text Figures}

1. NPV of Debt for the 27 Decision Point Countries..................................................10

2. NPV of Debt for the Countries that Reached the Completion Point

by mid-2003

3. Poverty-Reducing Expenditures and External Debt Service in the

27 Decision Point Countries

4. Gross Flows of Official External Resources to the 27 Decision Point Countries ..........12

5. Net Flows of Official External Resources to the 27 Decision Point Countries ...............13

Text Boxes

1. Some Cases of Interim Period Countries with Current and Extended Interruptions of

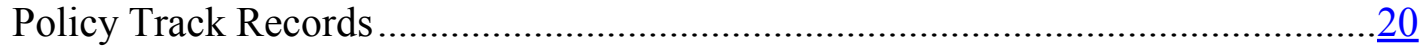

2. Examples of Structural and Social Completion Point Triggers .................................. 26

3. World Bank Operations Evaluation Department Review of the HIPC Initiative ........... $\underline{30}$

Text Tables

1. Debt Indicators for Developing Countries and HIPCs ........................................... 9

2. HIPCs in the Interim Period: Policy Performance Under PRGF-Supported

Programs Since the Decision Point, as of end-July 2003 .......................................

3. HIPCs in the Interim Period: Key Factors Affecting Policy Performance

in Countries That Have Had Delays in the Implementation of PRGF

Programs, as of end-July 2003 ......................................................................

4. HIPCs in the Interim Period: Time Taken from Interim PRSP to Full PRSP ...............

5. HIPCs in the Interim Period: Some Factors Delaying PRSP Preparation .....................23

6. HIPCs in the Interim Period: Status of Macroeconomic Policies and PRSP

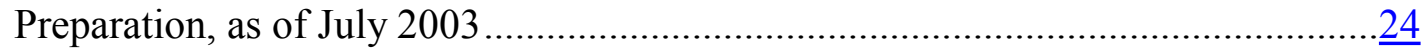

7. Creditors Involved in Litigation against HIPCs...............................................

Annexes

1. Country Coverage, Data Sources, and Assumptions for the

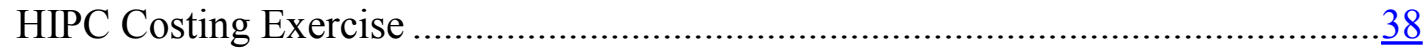

2. HIPC Initiative: Progress in Implementation by Country .......................................... $\frac{40}{43}$

3. Enhanced HIPC Initiative: Country Implementation Status Notes.............................. $\frac{43}{43}$

I. Implementation Status of HIPCs in the Interim Period ..................................... $\frac{43}{62}$

II. Countries that Could Reach the Decision Point After July 2003 ...........................62

III. Countries that Had Reached the Completion Point by the End of July 2003 ........69

Appendix Tables

1. Enhanced HIPC Initiative: Committed Debt Relief and Outlook................................77

2. Summary of Debt Service for the 27 HIPCs that Have Reached the Decision Points .. $\underline{78}$

3. Debt Service by Individual HIPCs that Have Reached the Decision Points by Country ............................................................................................. 79

4. Summary of Poverty-reducing Expenditures by the 27 HIPCs that Have Reached the Decision Points ..................................................................................... 82

5. Poverty-Reducing Expenditures by Individual HIPCs that Have Reached the Decision Points - by Country 
6. HIPC Initiative: Changes in the Estimates of Potential Costs

by Creditor Group ……………………………………...................................

7. HIPC Initiative: Breakdown of Estimated Potential Costs by Main Creditors and by Country Groups.............................................................. 85

8. HIPC Initiative: Estimates of Costs to Multilateral Creditors and Status of Their Commitments

9. HIPC Initiative: Status of Delivery of Assistance by the World Bank ............................ $\frac{87}{88}$

10. HIPC Initiative: Estimated Delivery of World Bank Assistance, 2000-09.................... $\frac{88}{89}$

11. HIPC Initiative: Status of Commitments by the IMF ………………………...........

12. HIPC Initiative: Estimated Delivery of IMF Assistance, 1998-2010 …………............

13. Status of Bilateral Donor Pledges to the HIPC Trust Fund .........................................

14. HIPC Initiative: Estimated Paris Club Costs, by Creditor Country …………………....93

15. HIPC Initiative: Paris Club Debt Relief.......................................................................

16. Paris Club Creditors' Delivery of Debt Relief Under Bilateral Initiatives:

Beyond the HIPC Initiative.

17. HIPC Initiative: Estimated Non-Paris Club Official Bilateral Creditors'

Costs, by Creditor Country .............................................................................. 98

18. HIPC Initiative: Delivery of Assistance by Non-Paris Club Creditors ……………......102 


\section{ABBREVIATIONS AND ACRONYMS}

AfDB

AFESD

AMF

AsDB

BADEA

BCEAO

BDEAC

BDEGL

BEAC

BOAD

CABEI

CAF

CAS

CDB

CIRR

CMCF

DRC

DSA

EADB

ECOWAS

EIB

EU

EUR

FEGECE

FOCEM

FONPLATA

FSID

GDF

GDP

HIPC

IDB

IBRD

IDA

IFAD

IFMIS

IMF

I-PRSP

IsDB

MDB

MTEF

NPV

OPEC

PTA

PEM

PERs

PRGF

PRSP

SDR

SMP

U.A.E.

ZESCO

ZNCB
African Development Bank

Arab Fund for Social and Economic Development

Arab Monetary Fund

Asian Development Bank

Arab Bank for Economic Development in Africa

Central Bank of West African States

Banque de Développement des États de l'Afrique Centrale

(Central African States Development Bank)

Banque de Développement des États des Grand Lacs

(Development Bank of Great Lake States)

Banque des États de l'Afrique Centrale (Bank of Central African States)

Banque Ouest Africaine de Developpement (West African Development Bank)

Central American Bank for Economic Integration

Corporación Andina de Fomento

County Assistance Strategy

Caribbean Development Bank

Commercial Interest Reference Rate

Caricom Multilateral Clearing Facility

Democratic Republic of Congo

Debt Sustainability Analysis

East African Development Bank

Economic Community of West African States

European Investment Bank

European Union

Euro

Fonds d'Entraide et de Garantie des emprunts du Conseil del'Entente

Fondo Centroamericano de Estabilización Monetaria

Fund for the Financial Development of the River Plate Basin

Fund for Solidarity and Economic Development

Global Development Finance

Gross Domestic Product

Heavily Indebted Poor Country

Inter-American Development Bank

International Bank for Reconstruction and Development

International Development Association

International Fund for Agricultural Development

Integrated Financial Management Information System

International Monetary Fund

Interim Poverty Reduction Strategy Paper

Islamic Development Bank

Multilateral Development Bank

Medium-Term Expenditure Framework

Net Present Value

OPEC Fund for International Development

Eastern and Southern African Trade and Development Bank

Public Expenditure Management

Public Expenditure Reviews

Poverty Reduction and Growth Facility

Poverty Reduction Strategy Paper

Special Drawing Rights

Staff Monitored Program

United Arab Emirates

Zambian Electricity Supply Company

Zambia National Commercial Bank 


\section{Executive Summary}

Progress in implementation. Twenty-seven heavily indebted poor countries (HIPCs) or more than two-thirds of the 38 countries that potentially qualify for assistance under the HIPC Initiative have reached the decision point, the most recent being the Democratic Republic of Congo in July 2003. In net present value (NPV) terms, these 27 countries account for 85 percent of the total expected relief for the 34 HIPCs for which data are available. Eight HIPCs have reached the completion point, the most recent being Mali and Benin in March 2003. The process of reaching the completion point has generally taken longer than earlier envisaged. Cost estimates for the 34 HIPCs are little changed from estimates from September 2002.

Reductions in debt and debt service and increases in poverty-reducing expenditures. As a result of HIPC relief, debt stocks for the 27 HIPCs that have reached the decision point are expected to decline by about two-thirds in NPV terms. Debt service-to-exports indicators have also been substantially reduced in most of these HIPCs. Savings from lower debt-service payments have contributed to a substantial increase in poverty-reducing expenditures.

Additionality. A key premise of the HIPC Initiative is that the debt relief provided should be additional to other forms of external financing assistance. Revised figures on debt relief and net aid flows appear to suggest that this has been the case.

Progress in implementing the Poverty Reduction and Growth Facility (PRGF). Despite the challenge of maintaining macroeconomic stability, 11 of the 19 countries currently in the period between the decision point and completion point (the interim period) have satisfactory performance records in their macroeconomic programs. Four countries could resume their PRGF-supported programs over the next few months; the remaining countries will need more time to begin the process of establishing an adequate performance record. Extended interruptions to PRGF program implementation and macroeconomic stability reflect many factors, with fiscal policy slippages, primarily expenditure overruns, the most common. Weak budget execution and poor policy implementation are often associated with limited institutional capacity, weak governance and deteriorating political and security conditions.

Progress in implementing Poverty Reduction Strategies. The requirement to satisfactorily implement a Poverty Reduction Strategy for one year will not, in itself, be a constraint to most interim-period HIPCs. Among HIPCs that have prepared full Poverty Reduction Strategy Papers (PRSPs), this requirement could only affect the timing of completion point in four cases.

Progress in implementing structural and social triggers. Social and structural completion point triggers have not been the proximate cause of delays so far but they could become so in the future. Most countries have made substantial progress with respect to these triggers, although in some cases additional progress will be needed.

Progress in reaching the decision point. Reaching the decision point remains a substantial challenge for the 11 potentially eligible HIPCs that have not done so. Most of these countries are affected by conflict and several have protracted arrears. A few of these countries could start 
establishing a policy performance record before the sunset clause takes effect by the end of 2004, in order to reach the decision point.

Debt sustainability. The HIPC Initiative was intended to deal with the overall debt burden of heavily indebted low-income countries by removing their debt overhang, but it cannot ensure debt sustainability into the future. As the recent World Bank Operations Evaluation Department Review of the HIPC Initiative stressed, reductions in the debt stock through the Initiative were expected to contribute to a more comprehensive development effort but not to supplant it. The Bank and Fund, together with other development partners, have organized a series of workshops on debt sustainability in the context of achieving the Millennium Development Goals (MDGs) in low-income countries, including HIPCs. By the end of the year staff of the Bank and the Fund are to produce a paper for the Boards that will address the policy implications of debt sustainability and will reflect many of the conclusions reached in these workshops.

Governance. Good governance is essential to the success of the HIPC Initiative. The current HIPC framework is fully supportive of good governance policies and includes related conditions and indicators. The Initiative forms part of a broader effort by the international community to support improvements in governance in these countries.

Creditor participation. The commitment by Libya in September 2002 to participate in the Initiative and the decision by India in June 2003 to write off loans to HIPCs has improved the level of participation in the Initiative by non-Paris Club bilateral creditors. Participation by commercial creditors has been limited, although their share of the outstanding debt stock in the 34 HIPCs is small (less than five percent of the total). The small share of commercial debt partly reflects the fact that much of the value of commercial debt in HIPCs has been eliminated through the Debt Reduction Facility for IDA-only Countries. 


\section{INTRODUCTION}

1. This report reviews implementation of the Heavily Indebted Poor Countries (HIPC) Initiative since the last report of September 2002. ${ }^{1}$ In addition to updating the information on the delivery of HIPC debt relief and associated assistance, it updates the estimated costs of the HIPC Initiative and the status of creditor participation. It examines the key factors affecting the pace of implementation of the Initiative including specific impediments in countries that have experienced difficulties making progress towards reaching the decision and completion points. The report briefly examines the issues of governance, maintenance of long-term debt sustainability and the calculation of additional debt relief at the completion point, issues that are treated more fully in separate papers. ${ }^{2}$

2. The key objective of the HIPC Initiative is to deal comprehensively with the overall external debt burden of eligible countries by removing their debt overhang within a reasonable period of time and providing a base from which to achieve debt sustainability and exit the rescheduling cycle. ${ }^{3}$ The framework of the Initiative also provides a way forward for HIPCs to effectively use the resources released from lower debt-service payments toward poverty-reducing expenditures. The scope of the objectives of the HIPC Initiative and the use of HIPC savings for poverty-reducing expenditures were part of the focus of a review by the World Bank Operations Evaluation Department which highlighted the achievements of the initiative and pointed out potential areas for improvement. ${ }^{4}$ In line with these objectives, those HIPCs committed to achieving and maintaining macroeconomic stability, and pursuing reforms aimed at improving governance, stimulating growth, and reducing poverty can benefit from substantial debt relief. To this end, over US $\$ 31$ billion of debt relief in NPV terms has been committed to date to 27 countries that have reached the decision point (Appendix Table 1). In conjunction with other resource flows, social and poverty reduction expenditures have increased significantly in most HIPCs. Nevertheless, in terms of countries reaching decision and completion points, progress has been slower than that originally envisaged by the international community and by the country authorities themselves.

\footnotetext{
${ }^{1}$ A six-monthly statistical update was also issued in March, 2003. See IMF and World Bank, "Heavily Indebted Poor Countries (HIPC) Initiative_-Statistical Update,” March 11, 2003, SM/03/91, SUP. 1, http://www.imf.org/external/np/hipc/doc.htm, and March 10, 2003, IDA/R2003-0042, http://www.worldbank.org/hipc.

${ }^{2}$ See IMF, "Debt Sustainability in Low-Income Countries_-Towards a Forward Looking Strategy,” May 28, 2003, $\mathrm{SM} / 03 / 185$, http://www.dse.de/ef/debts/index.htm.

${ }^{3}$ See IMF and World Bank, "Modifications to the Heavily Indebted Poor Countries (HIPC) Initiative," July 23, 1999, EBS/99/138, http://www.imf.org/external/np/hipc, and July 26, 1999, IDA/SecM99-475, http://www.worldbank.org/hipc.

${ }^{4}$ See World Bank, Operations Evaluation Department, "Debt Relief for the Poorest - An OED Review of the HIPC Initiative," February 24, 2003, http://www.worldbank.org/oed.
} 


\section{Progress in Implementation}

Debt stocks in the 27 HIPCs that had reached the decision point by July 2003 are projected to decline by about two-thirds once they reach their respective completion points. HIPCs in the interim period have benefited from Paris Club debt relief as well as relief from several multilateral creditors under the HIPC Initiative. This relief lowered debt-service ratios immediately after the decision point. The data suggest that HIPC relief delivered since 1998 has been additional to other forms of external financing assistance. Since September 2002 two HIPCs have reached their completion points and one has reached the decision point.

\section{A. Reduction in Debt Stocks and Debt Service}

\section{Debt stocks in the 27 HIPCs that have reached the decision point are projected to} decline by about two-thirds. In 2002 NPV terms, such debt stocks are projected to fall from an estimated US\$77 billion before traditional relief to US\$32 billion after the full delivery of traditional debt relief and assistance under the HIPC Initiative, and to US\$26 billion after the delivery of additional bilateral relief committed by several creditors (Figure 1). ${ }^{5}$ Debt-stock reduction in the eight countries that reached their completion points averaged more than 60 percent in 2002 NPV terms (Figure 2). ${ }^{6}$

\section{The HIPC Initiative is projected to substantially lower debt indicators at the} completion point to levels comparable to other developing and low-income countries (Table 1). ${ }^{7}$ The weighted average NPV of the debt-to-exports ratio for the 27 decision point countries is projected to decline from almost 300 percent before HIPC relief at the decision point to 128 percent by 2005 when most HIPCs are expected to have reached their completion points. The weighted average NPV of the debt-to-GDP ratio is projected to decline from 60 percent before HIPC relief at the decision point to 30 percent in 2005. These projected levels are close to those of other low-income countries. By 2001, the average debt-service-to-exports ratio for HIPCs had already fallen to below the corresponding ratio in other low-income countries.

5. HIPC relief is projected to substantially lower the debt-service-to-exports ratio for most HIPCs that have reached the decision point. HIPCs in the interim period benefit from Paris Club debt relief as well as interim relief from key multilateral creditors. The debt-service-

\footnotetext{
${ }^{5}$ Traditional relief refers to Naples terms stock-of-debt operations, involving a 67 percent NPV reduction.

${ }^{6}$ The 2003 projections for the eight completion point countries are based on the assumption of full creditor participation. This assumption tends to overstate the achieved debt reduction, but financing assurances already obtained for these countries average approximately 90 percent of total required HIPC relief.

${ }^{7}$ The comparability of NPV statistics derived from Global Development Finance (GDF) data (on developing countries) and HIPC documents and staff estimates (on HIPCs) is limited by the use of different methodologies to account for debt relief and differences in debt coverage. Debt relief is reflected in the GDF database only when actual debt relief agreements are signed, whereas debt relief estimates in HIPC country documents are based on the assumption of full creditor participation in the HIPC Initiative. Furthermore, debt indicators for HIPCs cover only public and public-guaranteed debt whereas debt indicators for developing countries cover total public and private debt. GDF debt-service data typically overstate debt service because grants associated with HIPC relief were accounted for separately until 2001.
} 
to-exports ratio for the 27 decision point countries declined from an average of 15.7 percent in 1998 and 1999 to 9.9 percent in 2002 (Appendix Tables 2 and 3). Significant debt-service reductions occur before the completion point due to the provision of interim relief; indeed, in 2002 the debt-service-to-exports ratio was 9.9 percent on average for both the group of HIPCs in the interim-period and HIPCs that reached the completion point. ${ }^{8}$

Table 1. Debt Indicators for Developing Countries and HIPCs

(Percent, weighted averages)

\begin{tabular}{lcccccc}
\hline & \multicolumn{2}{c}{ Developing Countries } & \multicolumn{2}{c}{ HIPC Countries 1/ } \\
\cline { 2 - 7 } & $\begin{array}{c}\text { Developing } \\
\text { countries } \\
\text { average } \\
20012 /\end{array}$ & $\begin{array}{c}\text { Non-HIPC } \\
\text { low-income } \\
\text { countries } \\
2001\end{array}$ & $\begin{array}{c}\text { Before } \\
\text { enhanced } \\
\text { HIPC } \\
\text { relief 3/ }\end{array}$ & $\begin{array}{c}\text { Debt } \\
\text { indicators for } \\
2001\end{array}$ & $\begin{array}{c}\text { Debt } \\
\text { indicators for } \\
2002\end{array}$ & $\begin{array}{c}\text { After enhanced } \\
\text { HIPC relief at } \\
\text { the completion } \\
\text { point }\end{array}$ \\
\hline $\begin{array}{l}\text { NPV of debt-to- } \\
\text { exports ratio 4/ }\end{array}$ & 120 & 143 & 274 & 275 & 214 & $1285 /$ \\
$\begin{array}{l}\text { NPV of debt-to- } \\
\text { GDP ratio }\end{array}$ & 38 & 39 & 61 & 65 & 50 & $305 /$ \\
$\begin{array}{l}\text { Debt service-to- } \\
\text { exports 6/ }\end{array}$ & 19 & 15 & $167 /$ & 10 & & 10 \\
\hline
\end{tabular}

Sources: Global Development Finance (GDF), World Bank 2003; HIPC country documents; and staff estimates.

Note: Figures represent weighted averages. Former SFR Yugoslavia, Liberia, Somalia, and Turkmenistan have been excluded because of incomplete data.

1/ HIPC countries refers to the 27 countries that had reached the decision point by the end of July 2003 under the enhanced HIPC Initiative.

2/ Developing countries comprise low- and middle-income countries according to the World Bank income classification.

3/ Debt stocks are after traditional Paris Club relief before the decision point. Data refer mostly to end-1998 and end-1999; for the Democratic Republic of Congo, data refer to end-June, 2002.

4/ Exports are defined as the three-year average exports of goods and services up to the dates specified.

5/ Data are for 2005. Since the Democratic Republic of Congo is expected to reach its completion point only in 2006, the NPV of debt after enhanced HIPC relief assumed committed unconditionally is used.

6/ Exports are defined as exports of goods and services in the current year.

7/ Average over 1998 and 1999.

6. Poverty-reducing expenditures in the 27 countries that have reached the decision point were almost four times as great as debt-service payments in 2002 (Figure 3 ). ${ }^{9}$ Annual debt service by the 27 decision point countries is projected to be about 30 percent lower during 2001-05 than in 1998 and 1999, freeing about US\$1.0 billion in annual debt-service savings. Poverty-reducing expenditures, meanwhile, increased from about US\$6.1 billion in 1999 to

\footnotetext{
${ }^{8}$ An exception is the Democratic Republic of Congo, where debt-service ratios rise significantly after the enhanced decision point. The increase is partly due to the resumption of debt-service payments following the arrears clearance operation, as the Democratic Republic of Congo had not been servicing most of its debt in the previous period.

${ }^{9}$ The definition of poverty-reducing expenditures varies across countries although many countries include primary education and basic health as well as expenditures for rural development. Country-specific definitions are included in Appendix Table 5.
} 
US $\$ 8.4$ billion in 2002 and are projected by staffs to increase to US\$11.9 billion in 2005 (Appendix Tables 4 and 5). ${ }^{10}$

Figure 1. NPV of Debt for the 27 Decision Point Countries

(In billions of U.S. dollars, in $2002 \mathrm{NPV}$ terms)

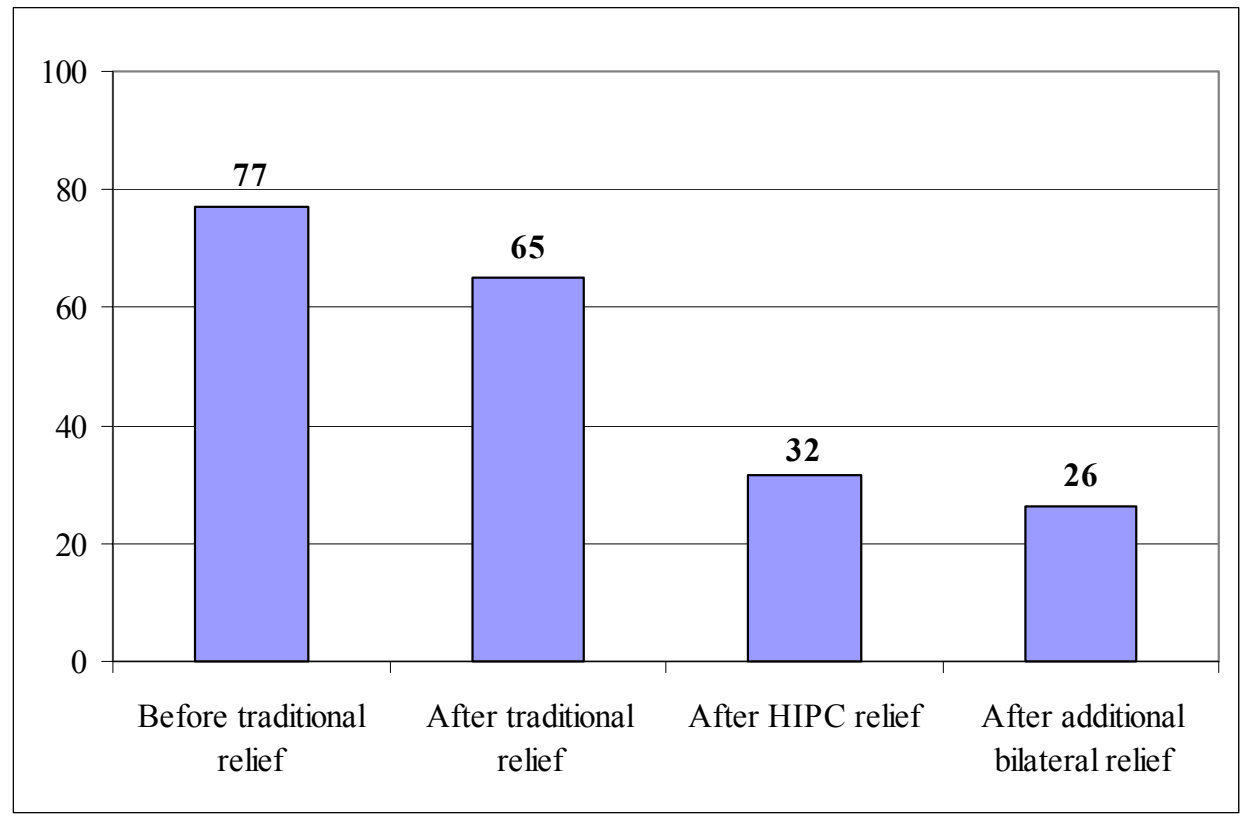

Source: HIPC Initiative country documents; and World Bank and IMF staff estimates.

\footnotetext{
${ }^{10}$ Country authorities are putting in place public expenditure management systems that would ensure the efficiency of poverty-reducing expenditures. See IMF and World Bank, "Actions to Strengthen the Tracking of Poverty Reducing Public Spending in Heavily Indebted Poor Countries (HIPCs)," March 22, 2002, SM/02/30 REV. 2, http://www.imf.org/external/np/hipc/doc.htm, and March 22, 2002, IDA SecM2002-30/2, http://www.worldbank.org/hipc.
} 
Figure 2. NPV of Debt for the Countries that Reached the Completion Point by mid-2003 (In billions of U.S. dollars, in 2002 NPV terms)

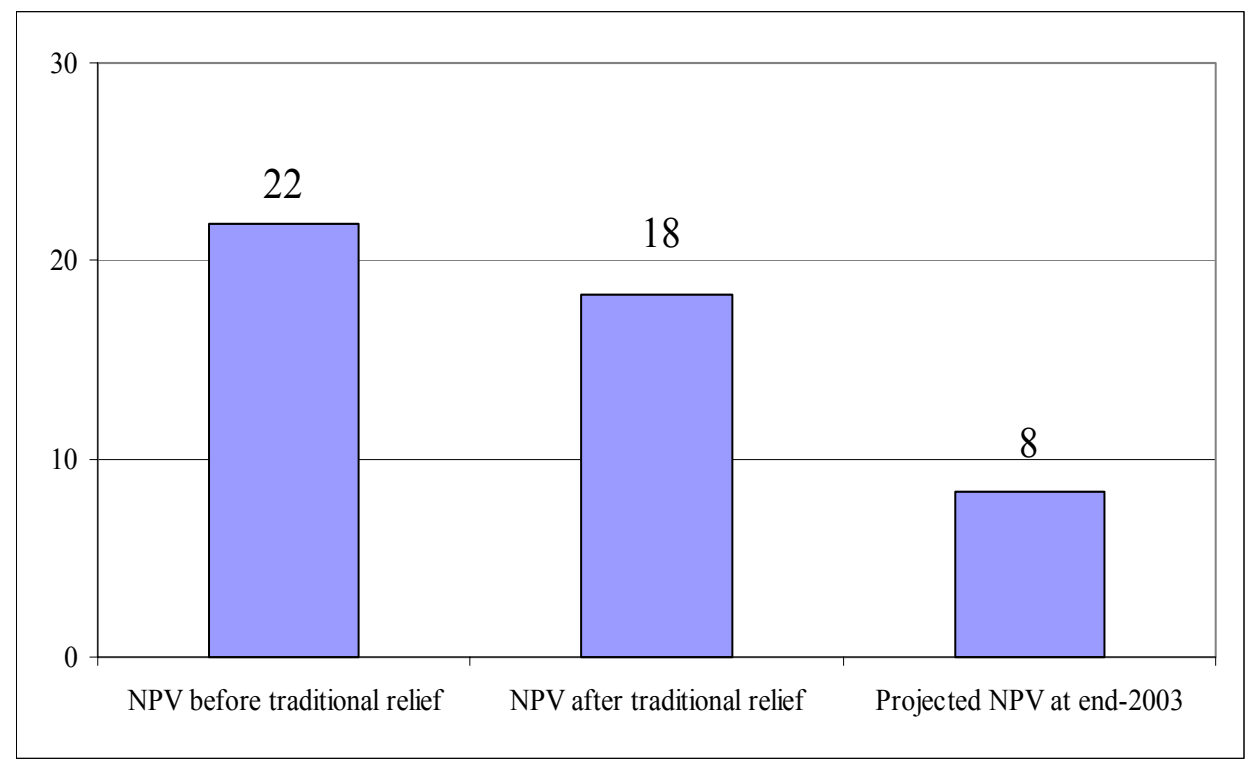

Source: HIPC Initiative country documents; and World Bank and IMF staff estimates.

Figure 3. Poverty-Reducing Expenditures and External Debt Service in the 27 Decision Point Countries

(In billions of U.S. dollars)

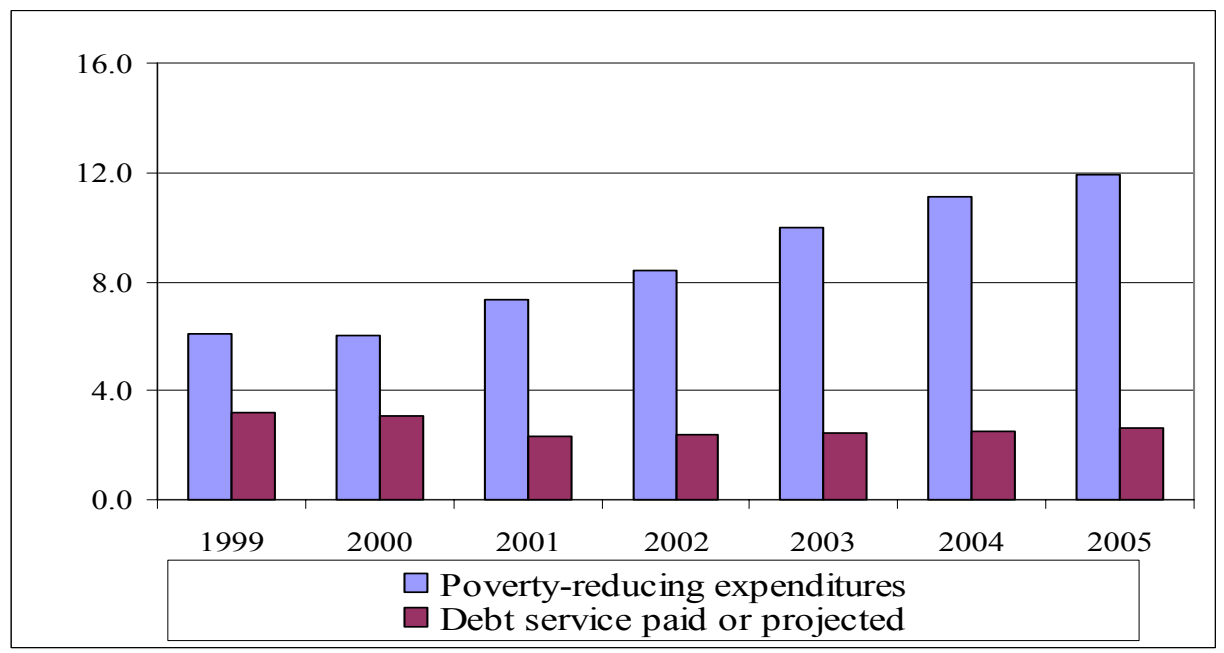

Source: HIPC documents and IMF staff estimates. 


\section{B. Resource Flows to HIPCs}

7. A key premise of the HIPC Initiative--that debt relief should be additional to other forms of external financing assistance--appears to be borne out by the facts. For the 27 decision point countries, both gross and net flows increased during 1997-2002. ${ }^{11}$ On a gross basis, official flows increased from about US\$8 billion in 1997 to almost US\$12 billion in 2002 with half of the increase due to HIPC relief (Figure 4). Net resource flows (i.e., difference between gross resource inflows and debt service payments) also increased substantially once the enhanced HIPC Initiative got under way (Figure 5). It should be noted however, that official external financing flows to the 27 decision point countries declined substantially in the mid1990s (as they did to other low-income countries). ${ }^{12}$ The recent increase in these flows restores external financing to levels of the early 1990s. ${ }^{13}$

Figure 4. Gross Flows of Official External Resources to the 27 Decision Point Countries (In billions of U.S. dollars)

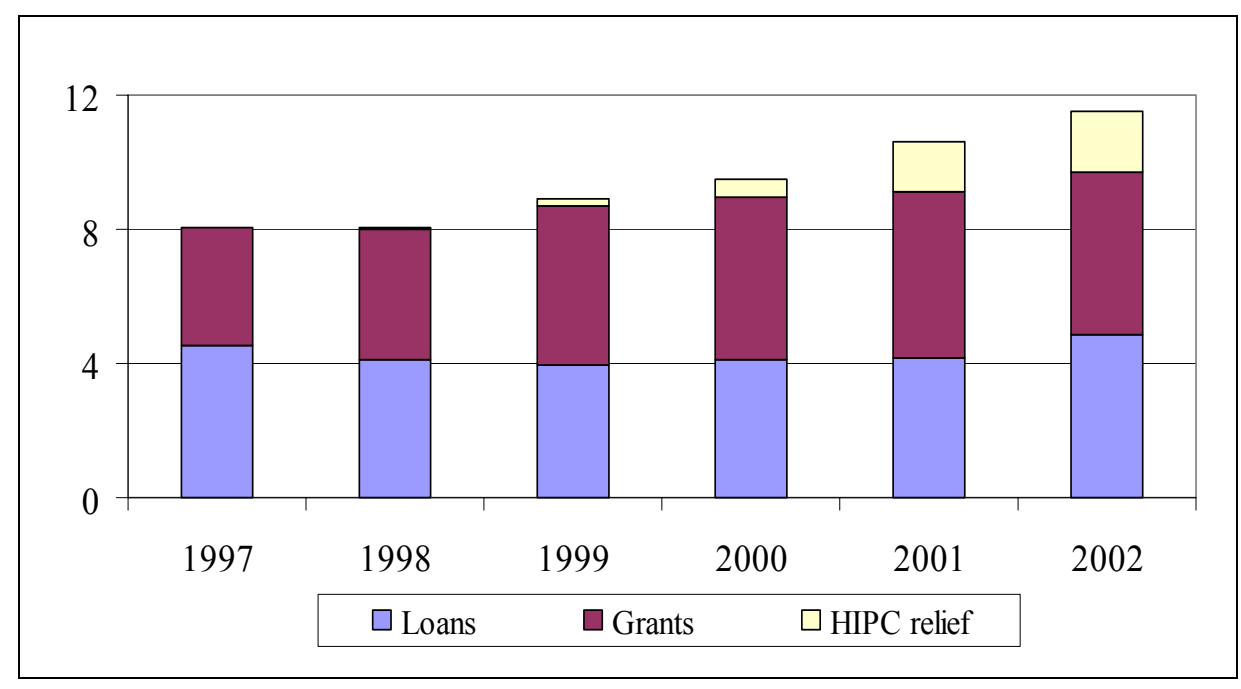

Source: HIPC documents and IMF staff estimates.

\footnotetext{
${ }^{11}$ Gross official resource flows are defined as the sum of all external loans and grants disbursed from official sources and HIPC debt relief provided by official creditors. Net official resource flows are defined as the difference between gross official resource flows and debt-service payments. Debt service payments and loan and grant disbursements are based on Balance of Payments data. HIPC debt relief is calculated as the difference between debt service due after traditional relief (obtained from HIPC documents) and debt service payments after HIPC relief. The World Bank Operations Evaluation Department also examines this issue. See World Bank Operations Evaluation Department, "Debt Relief for the Poorest," op. cit.

12 The decline in aid flows during this period is discussed in Global Development Finance (1999). Fiscal consolidation in many donor countries is identified as an important reason for the decline in aid budgets.

${ }^{13}$ For a discussion of recent developments in aid flows see Global Development Finance (2003).
} 
Figure 5. Net Flows of Official External Resources to the 27 Decision Point Countries 1/

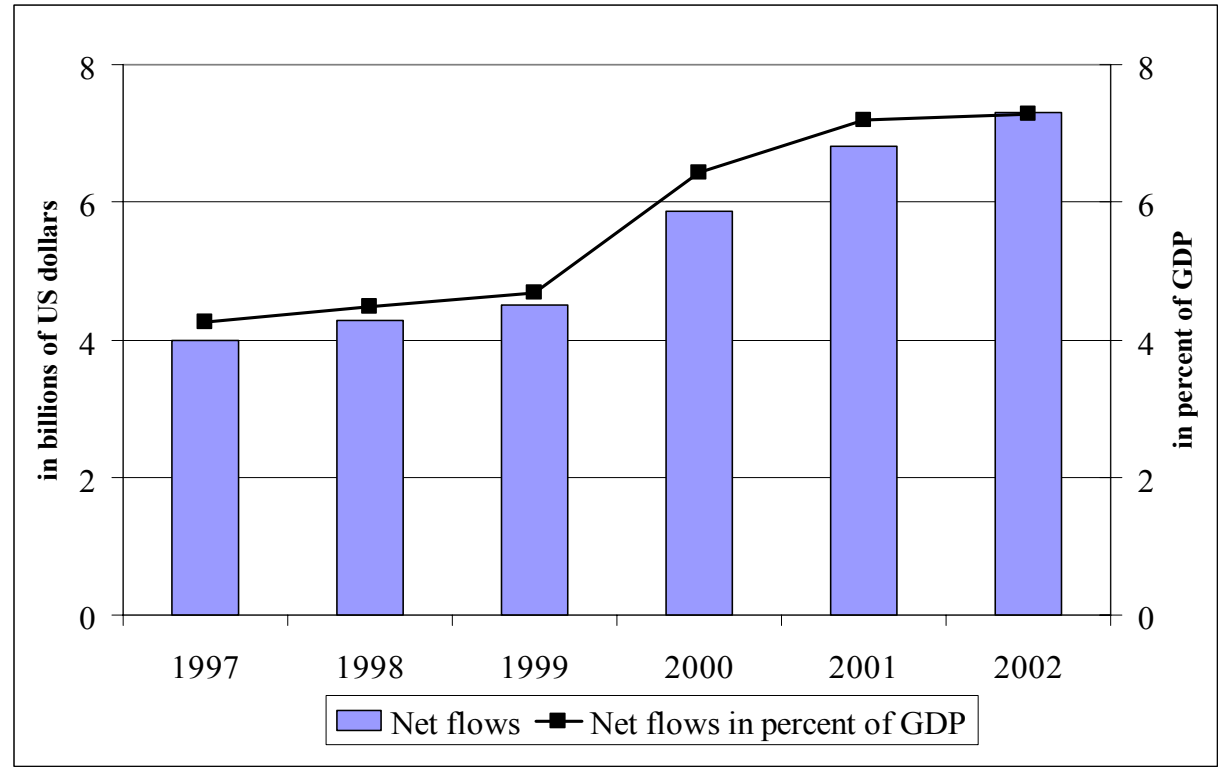

Source: HIPC documents and IMF staff estimates.

1/ Gross official resource flows are defined as the sum of all external loans and grants disbursed from official sources and debt relief provided by official creditors. Net official resource flows are defined as the difference between gross official resource flows and debt service payments. 
8. The overall increase in resource flows masks differences across countries and the important role that program and policy performance may have played in attracting official resources. Average external financing flows in 2000-02 increased for most of the 27 decision point countries relative to average levels in 1997-99 but this was not the case in eight HIPCs. Five of these countries (Guinea-Bissau, Malawi, Nicaragua, São Tomé and Príncipe, and Senegal) went through protracted interruptions in their PRGF-supported programs, which dampened aid inflows. Two other countries (Mali and Mauritania) experienced delays in grant or loan disbursements. Rwanda benefited from very high inflows during the late 1990s, though they ebbed somewhat in the following years.

\section{Implementation and Cost Update}

9. Since September 2002, Benin and Mali reached their completion points and the Democratic Republic of Congo (DRC) reached its decision point. Côte d'Ivoire did not reach its decision point, as anticipated in September 2002, because of civil strife that began in September 2002 and continued into 2003. For similar reasons a preliminary document could not be completed for the Central African Republic. Looking ahead, Ethiopia, Guyana, Nicaragua, Niger, Rwanda, and Senegal could reach their completion points by the end of 2003 or early in 2004 and the Republic of Congo could have a preliminary document prepared in the next few months, barring unanticipated complications (see Appendix II and Appendix III).

10. The total cost of the HIPC Initiative for 34 HIPCs is estimated at US\$39.4 billion in 2002 NPV terms. This estimate does not include the costs for Liberia, Somalia, Sudan, or Lao PDR due to data problems and in some cases protracted arrears. In 2001 NPV terms, costs for the 34 countries are estimated at US\$37.3 billion, little changed from the September 2002 estimate of US\$37.2 billion. ${ }^{14}$ Of the total cost in 2002 NPV terms, US\$33.3 billion is associated with the 27 countries that have reached the decision point (Appendix Table 7). These costs are about equally divided between bilateral and multilateral creditors. In nominal terms, these costs represent about US\$51.1 billion in debt-service relief over time.

11. Preliminary calculations suggest that including Sudan, Liberia, Somalia, and Lao PDR could increase the cost of HIPC relief by more than 25 percent or US\$10.6 billion to US\$50.0 billion in 2002 NPV terms. Most of these additional costs are concentrated in Sudan (see Appendix III). These estimates do not include Angola, Kenya, Vietnam, or Yemen, which are estimated to have debt ratios below the HIPC thresholds.

\footnotetext{
14 The underlying assumptions and caveats are detailed in Annex I. The cost revisions are due to a change in the discount rate from 6.0 percent to 5.45 percent (to reflect the decline in world interest rates) and to new debt sustainability analyses for the Democratic Republic of Congo and Mali. The effect of the change in the discount rate on the cost estimate is small, having almost no effect on costs in 2001 NPV terms and reducing costs in 2002 NPV terms by approximately US\$230 million. For the Democratic Republic of Congo the revisions resulted in an increase in HIPC debt relief costs of about US\$170 million in 2001 NPV terms. Revisions to costs resulting from Mali’s debt sustainability analysis were marginal.
} 
12. The cost of HIPC debt relief could increase by an estimated US\$729 million because of topping up of HIPC assistance at the completion point. ${ }^{15}$ Under the enhanced HIPC Initiative, in exceptional cases consideration can be given to providing additional debt relief at the completion point beyond that committed at the decision point. Eligibility for additional relief at the completion point is determined on a case-by-case basis and may be applied in cases where countries suffer from an exogenous shock that leads to a fundamental change in the country's economic circumstances. ${ }^{16}$ The fact that a country's debt burden exceeds the HIPC ratios at the completion point neither indicates eligibility for additional assistance nor the existence of serious debt sustainability problems. Current estimates suggest that 7 of the 19 interim period countries could have debt above the HIPC thresholds when they reach their completion points.

\section{Challenges in Reaching Completion Points and Decision Points}

Debt relief under the enhanced HIPC Initiative is provided on an irrevocable basis at the completion point after satisfactory completion of measures in three broad areas: maintaining macroeconomic stability, implementing a poverty reduction strategy developed through a broad participatory process, and implementing a pre-defined set of social and structural reforms. Delays in reaching the completion point have been attributed to the challenge of maintaining macroeconomic stability and preparing and implementing Poverty Reduction Strategies. Most countries that faced such challenges have either adopted the necessary policy changes or are making efforts toward doing so. Preparing fully participatory PRSPs has taken longer than expected, but 15 of the 19 countries in the interim period have finalized them and will likely not be constrained by the one-year satisfactory implementation requirement from reaching the completion point in 2004. Good progress has been made in satisfying social and structural triggers. Although these triggers have not been the proximate cause of delays so far, they could cause delays in some countries in the future. Although the process of reaching the completion point has taken longer than anticipated and challenges remain in reaching the decision point, existing standards for policy performance are being maintained to ensure that the Initiative's objectives are reached. ${ }^{17}$

\footnotetext{
${ }^{15}$ Updated projections for the nineteen HIPCs between the enhanced HIPC decision and completion points suggest that the possible NPV of external debt above the HIPC thresholds at the completion point after assuming full delivery of HIPC relief and additional bilateral assistance would stand at US\$729 million. These cost estimates are very sensitive to changes in discount rate and exchange rate assumptions.

${ }^{16}$ HIPCs can be considered for topping up if either their NPV debt-to-export ratio is greater than 150 percent or, if they qualified as a fiscal case at the decision point, their NPV debt-to-fiscal revenues ratio is greater than 250 percent. See IMF and World Bank, "The Enhanced HIPC Initiative-Completion Point Considerations," August 21, 2001, EBS/01/141, http://www.imf.org/external/np/hipc, and September 10, 2001, IDA/R2001-152, http://www.worldbank.org/hipc. Also see IMF "Update on the Financing of PRGF and HIPC Operations and the Subsidization of Post-Conflict Emergency Assistance," March 20, 2003 SM/03/100, http://www.imf.org/external/np/hipc.

${ }^{17}$ This is consistent with the recommendation of the World Bank Operations Evaluation Department review which suggested maintaining standards for policy performance, and when the established criteria are to be relaxed, the rationale for doing so should be clear and transparent to ensure that Initiative's objectives are reached. See World Bank, Operations Evaluation Department, "Debt Relief for the Poorest" op. cit.
} 


\section{A. Challenges in Reaching Completion Points}

\section{Achieving Macroeconomic Stability}

13. Macroeconomic stability is necessary for underpinning sustainable growth and poverty reduction. The HIPC Initiative requires countries to have established a track record for macroeconomic performance and that appropriate macroeconomic polices be in place at the time of the completion point. As of the end of July 2003, more than half of the countries in the interim period-including the Democratic Republic of Congo, which reached the decision point in July 2003 - were satisfactorily implementing their macroeconomic programs, despite challenging global economic environment (Table 2). The remaining countries have either recently experienced problems in program implementation (Cameroon, The Gambia, Guinea, and Zambia) or do not have an IMF-supported program in place after protracted delays in establishing a satisfactory record of performance (Guinea-Bissau, Honduras, Malawi, and São Tomé and Príncipe).

\section{Maintaining macroeconomic stability has been a challenge for HIPCs during the} interim period and several countries have put corrective policies in place (Table 2). ${ }^{18}$ Most of the HIPCs in the interim-period that experienced problems in maintaining a satisfactory track record of macroeconomic performance have had difficulties implementing fiscal policy. Some have also had difficulty implementing key structural reforms (e.g., banking sector reforms in Ethiopia, public sector reforms in Guyana, and privatization in Zambia) (Table 3). Of the eight countries that had program interruptions of less than a year, Ghana, Ethiopia, Madagascar and Rwanda were able to implement corrective measures that facilitated program continuation and Cameroon, The Gambia, Guinea and Zambia are currently making efforts to implement measures that would allow them to do so. Among the seven countries that experienced interruptions of more than one year, Nicaragua and Senegal made intensified efforts to reduce their fiscal deficits and move forward on agriculture and other structural reforms, leading to approval of new PRGFsupported programs. In Guyana, the authorities are currently implementing measures to contain the public sector wage bill and restructure the sugar and bauxite sectors, measures that may pave the way for reaching the completion point.

\section{Currently four interim-period HIPCs remain with protracted program}

interruptions. Guinea-Bissau, Honduras, Malawi, and São Tomé and Príncipe have experienced severe difficulties in implementing their economic reform programs since reaching their decision points and currently face serious challenges in the areas of public resource management, governance, and in some cases, structural reforms (Table 3). Discussions of policies needed to establish a track record have failed in Guinea-Bissau due to changes in government. Regarding São Tomé and Príncipe discussions on a new three-year PRGF-supported program had been hampered by political tensions that culminated in an attempted coup d'état in July 2003. In Malawi the authorities have embarked on a strategy to strengthen public expenditure management. In Honduras the authorities are in the process of developing a program for fiscal

\footnotetext{
${ }^{18}$ The assessment in this section excludes the Democratic Republic of Congo, which recently reached the decision point.
} 
sustainability based on a social pact with political parties, unions and the private sector (see Annex III).

\section{Table 2. HIPCs in the Interim Period: Policy Performance Under PRGF-Supported Programs Since the Decision Point 1/} (As of end-July 2003)

\begin{tabular}{|c|c|c|c|c|}
\hline No Interruption & $\begin{array}{l}\text { Interruptions } \\
\text { of less than } \\
6 \text { months }\end{array}$ & $\begin{array}{l}\text { Interruptions of } \\
\text { between } 6 \text { and } \\
12 \text { months }\end{array}$ & $\begin{array}{l}\text { Interruptions of between } \\
1 \text { and } 2 \text { years }\end{array}$ & $\begin{array}{l}\text { Interruptions of } \\
\text { more than } 2 \text { years }\end{array}$ \\
\hline $\begin{array}{l}\text { Chad } \\
\text { Congo, Dem. Rep } \\
\text { Niger } \\
\text { Sierra Leone }\end{array}$ & $\begin{array}{l}\text { Cameroon 2/ } \\
\text { Ethiopia 3/ } \\
\text { Ghana 4/ } \\
\text { Rwanda 5/ } \\
\text { Zambia 6/ }\end{array}$ & $\begin{array}{l}\text { The Gambia 7/ } \\
\text { Guinea 8/ } \\
\text { Madagascar 9/ }\end{array}$ & $\begin{array}{l}\text { Guyana 10/ } \\
\text { Honduras 11/ } \\
\text { Nicaragua 12/ } \\
\text { São Tomé and Príncipe 13/ } \\
\text { Senegal 14/ }\end{array}$ & $\begin{array}{l}\text { Guinea-Bissau 15/ } \\
\text { Malawi 16/ }\end{array}$ \\
\hline
\end{tabular}

Source: IMF country documents.

Note. Countries shown in italics have been currently satisfactorily implementing their macroeconomic programs

1/ Interruptions of policy performance under PRGF-supported programs are defined as the period starting from the sixth month following the completion of a semi-annual program review or approval of a new PRGF arrangement by the Fund's Executive Board to the time when a PRGF program review is completed or a new PRGF arrangement is approved.

2/ The fourth review of the 2000/03 PRGF arrangement was delayed from March 2003.

3/ The 2001/04 PRGF program review was delayed from March to August 2003.

4/ The 1999/02 PRGF arrangement expired in November 2002 without completion of the final review. A new PRGF arrangement was approved in May 2003.

5/ The 1998/02 PRGF arrangement expired in April 2002 without completion of the final review. A new PRGF arrangement was approved in August 2002.

6/ The 1999/03 PRGF arrangement expired in March 2003 without completion of the final review. A new PRGF arrangement has not yet been established as of July 2003.

7/ The first review of the PRGF arrangement approved in July 2002 was delayed.

8/ The 2001/04 PRGF arrangement has been off track since December 2002.

9/ A political crisis in late 2001 led to an interruption of the 2001 PRGF supported program until December 2002.

10/ In early 2001, slippages in fiscal and structural policies led to interruption in the 1998/01 PRGF arrangement. A new PRGF arrangement was approved in September 2002 but the first review has been delayed owing to slow implementation of agreed structural reform actions. Most prior actions for the review have been completed and the remainder is expected to be completed shortly.

11/ The 1999/02 PRGF program has been interrupted twice. There was a 14-month lapse between the second and third reviews in June 2000 and October 2001. The PRGF expired at end 2002 and discussions are underway on a successor arrangement.

12/ The 1998/02 PRGF arrangement went off track in early 2001. Successive SMPs were implemented eventually leading to a new PRGF arrangement in December 2002.

13/ The 2000/03 PRGF arrangement went off track at end 2001.

14/ The 1998/02 PRGF arrangement expired in April 2002 without completion of the final review. A new PRGF arrangement was approved in April 2003.

15/ The 2000/03 PRGF arrangement has been off track since early 2001.

16/ The 2000/03 PRGF arrangement has been off track since early 2001. 


\section{Extended interruptions to PRGF program implementation and macroeconomic} stability reflected a confluence of factors (Table 3 and Box 1). Fiscal policy slippages have been the most common, generally stemming from overruns in the public sector wage bill, military expenditures, and other non-priority public spending often exacerbated by tax revenue shortfalls. Weak budget execution is often attributed to limited institutional capacity and adverse exogenous developments. ${ }^{19}$ Poor policy implementation also seems to have been associated with weak governance (e.g., large errors and omissions in the fiscal accounts of Guinea-Bissau and problems related to oil sector contracts in São Tomé and Príncipe) and political events (e.g., disruption of economic activity in Madagascar following a contested presidential election) or worsening political and security conditions that made it difficult to implement macroeconomic policies and structural reforms. Recently, difficult domestic political choices in São Tomé and Príncipe were compounded by an attempted coup d'état. Discussions have been underway to establish new PRGF arrangements with Honduras and São Tomé and Príncipe and to conclude the first PRGF review with Malawi.

\footnotetext{
${ }^{19}$ For a recent analysis of the impact of natural disasters and other shocks to export prices of low-income countries, see IMF, "Fund Assistance for Countries Facing Exogenous Shocks," SM/03/288, August 11, 2003. Adjustment mechanisms are typically built into PRGF-supported programs and program targets to accommodate exogenous shocks.
} 
Table 3. HIPCS in the Interim Period: Key Factors Affecting Policy Performance in Countries That Have Had Delays in the Implementation of PRGF Programs (As of end-July 2003)

\begin{tabular}{|c|c|c|c|c|}
\hline & Macroeconomic Policies & $\begin{array}{l}\text { Structural Reforms } \\
\text { (incl. on governance) }\end{array}$ & $\begin{array}{c}\text { Political/Security } \\
\text { Factors }\end{array}$ & $\begin{array}{c}\text { Exogenous } \\
\text { Shocks } \\
\end{array}$ \\
\hline \multicolumn{5}{|c|}{ Countries with interruptions/delays in PRGF-supported programs of less than six months } \\
\hline Cameroon & $\begin{array}{l}\text { Difficulties in reconciling fiscal data } \\
\text { provided by the Ministry of Finance and } \\
\text { the Central Bank and weak tax revenue } \\
\text { performance in } 2003 \text {. }\end{array}$ & & & \\
\hline Ghana & $\begin{array}{l}\text { Expenditure overruns in part due to } \\
\text { significant increase in wage bill; shortfall in } \\
\text { tax revenue }\end{array}$ & & & \\
\hline Rwanda & $\begin{array}{l}\text { Expenditure overruns in the wage bill and } \\
\text { a shortfall in tax revenue }\end{array}$ & & & \\
\hline Ethiopia & & $\begin{array}{l}\text { The completion of the } \\
\text { financial audit of the } \\
\text { Commercial Bank of } \\
\text { Ethiopia was delayed }\end{array}$ & & $\begin{array}{l}\text { Terms of trade deteriorated } \\
\text { resulting from lower export } \\
\text { prices for coffee and major } \\
\text { crop failure due to drought }\end{array}$ \\
\hline Zambia & Expenditure overruns in the wage bill & $\begin{array}{l}\text { Delays in implementation of } \\
\text { measures to divest Zambia } \\
\text { National Commercial Bank }\end{array}$ & $\begin{array}{l}\text { Exports adversely affected by } \\
\text { political turmoil in regional } \\
\text { trading partners }\end{array}$ & $\begin{array}{l}\text { Low agricultural output in } \\
2002 \text { because of poor and } \\
\text { uneven rainfall }\end{array}$ \\
\hline \multicolumn{5}{|c|}{ Countries with interruptions/delays in PRGF-supported programs of between six and twelve months } \\
\hline The Gambia & $\begin{array}{l}\text { Expenditure overruns due to debt service } \\
\text { payments and revenue shortfalls related to } \\
\text { weak tax administration. Monetary } \\
\text { expansion with credit growth far in excess } \\
\text { of targets }\end{array}$ & & $\begin{array}{l}\text { Border closures with Senegal } \\
\text { that impeded transit trade and } \\
\text { higher petroleum prices }\end{array}$ & $\begin{array}{l}\text { Major crop failure due to } \\
\text { delayed rains. }\end{array}$ \\
\hline Guinea & $\begin{array}{l}\text { Expenditure overruns due to defense and } \\
\text { election spending as well as weak } \\
\text { budgetary management }\end{array}$ & & $\begin{array}{l}\text { Security situation along } \\
\text { borders deteriorated }\end{array}$ & \\
\hline Madagascar & & & $\begin{array}{l}\text { Prolonged political crisis in } \\
2002 \text { had substantial adverse } \\
\text { economic effects and delayed } \\
\text { the second review }\end{array}$ & \\
\hline \multicolumn{5}{|c|}{ Countries with interruptions/delays in PRGF-supported programs of between one and two years } \\
\hline Guyana & $\begin{array}{l}\text { Expenditure overruns in wage bill and } \\
\text { shortfall in tax revenue }\end{array}$ & $\begin{array}{l}\text { Delays in public sector } \\
\text { reform, tax system reforms, } \\
\text { restructuring of the state- } \\
\text { owned bauxite and sugar } \\
\text { companies }\end{array}$ & $\begin{array}{l}\text { Domestic security situation } \\
\text { deteriorated in } 2002 \text { and } \\
\text { political instability adversely } \\
\text { affected the decision-making } \\
\text { process }\end{array}$ & \\
\hline Honduras & $\begin{array}{l}\text { Expenditure overruns in the wage bill and } \\
\text { a shortfall in tax revenue }\end{array}$ & $\begin{array}{l}\text { Delays in implementation of } \\
\text { civil service reform and } \\
\text { reform of the electricity } \\
\text { sector }\end{array}$ & & $\begin{array}{l}\text { Hurricane Mitch in } 1998 \text { and } \\
\text { later a significant decline in } \\
\text { coffee prices and slow down } \\
\text { in the U.S. economy }\end{array}$ \\
\hline Nicaragua & $\begin{array}{l}\text { Public sector deficit substantially exceeded } \\
\text { targets in } 2001 \text { due to weak taxpayer } \\
\text { compliance and increases in expenditure } \\
\text { prior to the elections. Monetary expansion } \\
\text { with credit growth far in excess of targets }\end{array}$ & $\begin{array}{l}\text { Delays in the privatization of } \\
\text { the telecommunications } \\
\text { company and electricity } \\
\text { generation plants. }\end{array}$ & $\begin{array}{l}\text { Commitments beyond } 2002 \\
\text { were not possible because of } \\
\text { imminent Presidential } \\
\text { elections }\end{array}$ & $\begin{array}{l}\text { Hurricane Mitch in } 1998 \text { and } \\
\text { later a terms of trade } \\
\text { shock-significant decline in } \\
\text { coffee prices and higher oil } \\
\text { prices }\end{array}$ \\
\hline $\begin{array}{l}\text { São Tomé } \\
\text { and Príncipe }\end{array}$ & $\begin{array}{l}\text { Expenditure overruns in the civil service } \\
\text { wage bill, utility and election costs }\end{array}$ & $\begin{array}{l}\text { Governance issues related } \\
\text { to oil-sector contracts, and } \\
\text { delays in the reform } \\
\text { measures for the utility } \\
\text { sector and the civil service }\end{array}$ & & \\
\hline Senegal & $\begin{array}{l}\text { Weak public finances due to problems with } \\
\text { the operations of the state-owned } \\
\text { electricity and groundnut enterprises }\end{array}$ & $\begin{array}{l}\text { Delays in reforms in the } \\
\text { pension system and the } \\
\text { groundnut sector }\end{array}$ & & $\begin{array}{l}\text { Low agricultural output in } \\
2002 \text { because of poor and } \\
\text { uneven rainfall }\end{array}$ \\
\hline \multicolumn{5}{|c|}{ Countries with interruptions/delays in PRGF-supported programs of more than two years } \\
\hline $\begin{array}{l}\text { Guinea- } \\
\text { Bissau }\end{array}$ & $\begin{array}{l}\text { Fiscal policy slippage-loss of budgetary } \\
\text { control in } 2000 \text {, due to expenditure } \\
\text { overruns largely on defense spending. } \\
\text { Monetary expansion with credit growth far } \\
\text { in excess of targets }\end{array}$ & $\begin{array}{l}\text { Large errors and omissions } \\
\text { in budget execution; } \\
\text { measures to address } \\
\text { weaknesses in public } \\
\text { resource management were } \\
\text { not observed }\end{array}$ & $\begin{array}{l}\text { Transition after } 1999 \text { civil } \\
\text { conflict has been difficult. } \\
\text { Parliament dissolved since } \\
11 / 02 \text {-adversely affects the } \\
\text { decision-making process }\end{array}$ & $\begin{array}{l}30 \text { percent decline in cashew } \\
\text { nut prices in } 2001\end{array}$ \\
\hline $\begin{array}{l}\text { Malawi } \\
\text { Source: IMF }\end{array}$ & $\begin{array}{l}\text { Expenditure overruns related to the bail } \\
\text { out of parastatals, increased wage bill and } \\
\text { und taxes }\end{array}$ & $\begin{array}{l}\text { Delays in the } \\
\text { implementation of public } \\
\text { sector reform and } \\
\text { privatization }\end{array}$ & & $\begin{array}{l}\text { Food crises because of } \\
\text { uneven rainfall, drought and } \\
\text { floods. Terms of trade } \\
\text { deteriorated due to lower } \\
\text { export prices }\end{array}$ \\
\hline
\end{tabular}




\section{Box 1. Some Cases of Interim Period Countries with Current and Extended Interruptions of Policy Track Records}

Guinea Bissau. Guinea-Bissau's PRGF-supported program went substantially off-track soon after approval in December 2000. The reasons included a loss of budgetary control and large unauthorized expenditures equivalent to about 10 percent of GDP (mainly on defense) that were partly financed by credit from the banking system. By endJune 2001, the primary deficit was 3.5 percent of GDP higher than targeted and domestic arrears had increased by 2 percent of GDP. Moreover, measures to address weaknesses in financial administration were not implemented. In 2002, economic activity declined by more than 4 percent, adversely affecting the fiscal situation. Revenue declined 20 percent and there was a build-up in arrears. Efforts to revive the PRGF-supported program ceased in September 2002 despite attempts to institute corrective measures through two short-term macroeconomic programs in 2001 and 2002. Since then, discussions have ensued on an extended staff monitored program for 2003. These discussions were not completed because of the dissolution of parliament and the dismissal of the Government in November 2002. A caretaker government has been appointed until Parliamentary elections have been held which have been thrice delayed and now are expected by October 2003.

Honduras. Honduras's economic reform program has been off-track since end-2001 owing to weak fiscal policy implementation, primarily due to an overrun in the wage bill coupled with tax revenue shortfalls, and slow civil service reforms. Lower tax collections reflected weaknesses in tax and customs administration whilst wage increases granted to teachers and health workers contributed to the substantial growth in the wage bill to 10.7 percent of GDP, beyond the 9.3 percent of GDP specified in the PRGF-supported program. Progress on civil service reform, a key structural reform measure since October 2000 was slow, and legislation presented to congress at end-2001 did not meet the conditions envisaged in the program for strengthening the government's wage policy. The PRGF-supported program expired at end-2002. The authorities intend to develop a strategy to achieve fiscal sustainability on the basis of a social pact with political parties, labor unions, the private sector and civil society.

Malawi. Malawi's PRGF-supported program, approved in December 2000, went off track in 2001 before the conclusion of the first review because of increasing fiscal imbalances mostly from policy decisions to support lossmaking parastatals, augment civil servants' wages, increase other low-priority public spending, such as travel and representation, and reduce income taxes. The slippages were also exacerbated by a rising interest bill and weak revenue collections. Remedial fiscal measures proposed to reduce expenditure and enhance revenue through the remainder of 2001/02 were not implemented and resulted in a further deterioration in the fiscal situation. Program targets for the domestic budget deficit were exceeded by 3.5 percent and 7 percent of GDP in 2000/01 and 2001/02, respectively. The authorities have embarked on a strategy of measures to strengthen public expenditure management and a budget for 2003/04 consistent with the macroeconomic framework and reform agenda.

São Tomé and Príncipe. São Tomé and Príncipe’s PRGF-supported program, approved in April 2000, went off track during 2001 because of poor governance in public resource management, delays in implementing structural reforms including much needed reforms of the civil service and the utilities sector, and governance problems in the oil sector. Strong revenue mobilization was offset by expenditure overruns related to wage increases, payment of an oil sector contract and extra budgetary expenditures and resulted in a primary budget deficit of 3.0 percent of GDP in 2001 compared to the targeted surplus of 2.7 percent of GDP. Monetary targets (for net domestic assets and net international reserve targets) were not observed. Implementation of the subsequent IMF staff monitored program during the first half of 2002 was disappointing, as key program targets for end-June 2002 were not observed. There were spending overruns owing to trade union wage demands, higher energy and utility costs and the legislative elections of March 2002. The staff monitored program was extended through end-December 2002 leading to the reestablishment of a broadly satisfactory track record of policy implementation. This laid the basis for discussions on an economic program that could be supported by a PRGF arrangement. The understandings that were reached with staff on a new PRGF-supported program in early July 2003 will need to be reassessed in light of the attempted coup d'état of July 16, 2003.

Source: IMF country documents. 


\section{The HIPC Initiative has built in flexibility to prevent protracted delays in} macroeconomic programs impeding countries from reaching the completion point. In cases where a review under a PRGF-supported program is delayed or the PRGF-supported program is otherwise interrupted for a period of less than six months, the completion point could be reached at the same time that the PRGF review is completed or a new PRGF arrangement is approved. In the case of a delay or interruption of a PRGF-supported program of more than six months, the country is required to establish an uninterrupted track record of satisfactory performance for at least six months immediately before the completion point. ${ }^{20}$ Where PRGF programs have either lapsed or been discontinued, IMF staff have sought to work with the respective country authorities to implement Staff Monitored Programs that would facilitate the resumption of financial support from the international community. In principle therefore countries with protracted interruptions in their macroeconomic programs could be back on track within a short period of time and reach the completion point provided other conditions are met.

\section{Implementing Poverty Reduction Strategies}

18. The requirement to satisfactorily implement a PRSP for one year will not, in itself, be a constraint to most HIPCs in the interim period. ${ }^{21}$ Among HIPCs that have prepared PRSPs, the implementation requirement could affect the timing of the completion point in only four cases. At the end of July 2003, only four interim period HIPCs (the Democratic Republic of Congo, Guinea-Bissau, São Tomé and Príncipe, and Sierra Leone), some of which faced serious internal political constraints, had yet to complete a full PRSP. Sierra Leone reached its decision point only in 2002; preparations for the completion of a PRSP are underway there. The Democratic Republic of Congo reached its decision point only in July 2003. Of the 15 HIPCs in the interim period that had completed PRSPs, 11 had implemented their PRSPs for more than one year.

19. In most HIPCs, preparation of PRSPs through a broad participatory process has taken longer than initially anticipated. Most countries had expected to adopt full PRSPs within a year of adoption of the Interim Poverty Reduction Strategy Papers (I-PRSPs). The actual time between the I-PRSP and the full PRSP has averaged 1 1 $\frac{1}{2}$ to 2 years for HIPCs in the interim

\footnotetext{
${ }^{20}$ See IMF and World Bank, "Heavily Indebted Poor Countries (HIPC) Initiative: Status of Implementation," March 25, 2002, SM/02/94, http://www.imf.org/external/np/hipc/doc.htm, and March 22, 2002, IDA/SecM2002-0155, http://www.worldbank.org/hipc.

${ }^{21}$ Floating completion point triggers require the satisfactory implementation of the PRSP for at least one year. This requirement ensures the PRSP's integration with the macroeconomic framework and the effective spending of debt relief. The framework does provide that those countries indicated as retroactive cases do not have the one-year satisfactory implementation requirement. See IMF and World Bank, "Heavily Indebted Poor Countries (HIPC) Initiative - Strengthening the Link between Debt Relief and Poverty Reduction," August 26, 1999, EBS/99/168; SUP. 1, http://www.imf.org/external/np/hipc/doc.htm, and August 26, 1999, IDA/SecM99-545, http://www.worldbank.org/hipc.
} 
period (Table 4). A lesson that has emerged from PRSP reviews is that initial timetables were overly ambitious. ${ }^{22}$

Table 4. HIPCs in the Interim Period: Time Taken from Interim PRSP to Full PRSP 1/

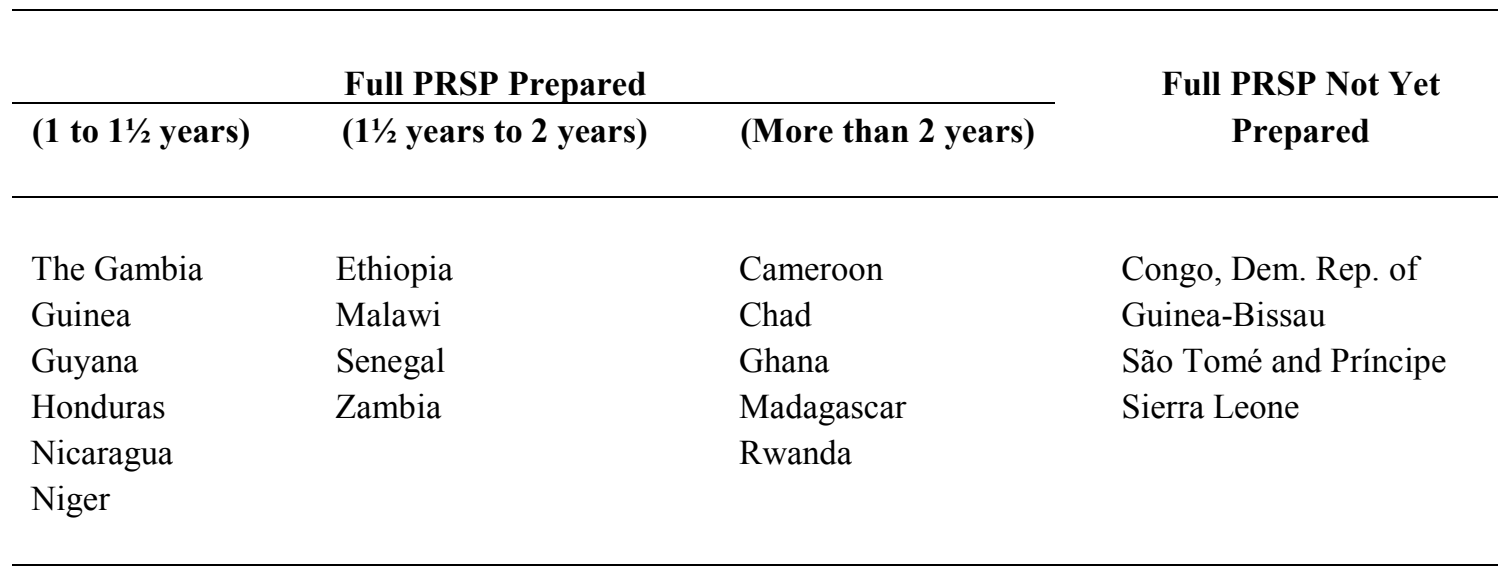

Source: IMF country documents.

1/ Time taken is calculated on the basis of submission of a full PRSP to the Bank and the Fund relative to the adoption of the Interim PRSP.

20. PRSP preparation status reports provide some explanations for the delays. Fully engaging all stakeholders in a participatory process, collecting and analyzing data, establishing priority objectives and sectoral strategies and undertake their costings have taken longer than expected. Difficulties in establishing public expenditure management systems and transparent mechanisms for monitoring the spending of debt relief, as well as the lack of institutional and human resource capacity have constrained the timely preparation of PRSPs in several countries in the interim period (Table 5).

\section{Delays in PRSP preparation have been accompanied by improved country}

ownership and quality of the PRSP process. These developments have been consistent with prevailing views since the launching of the PRSP approach. Authorities and stakeholders in HIPCs and the international community have emphasized the importance of country ownership and the quality of the PRSP process. The Boards of both the Fund and the Bank as well as development partners have stressed that ownership and quality should not be sacrificed for speed in reaching the completion point. Bank and Fund staff have been working with others to alleviate

\footnotetext{
${ }^{22}$ See IMF and World Bank "Review of the Poverty Reduction Strategy Paper Approach: Early Experience with I-PRSPs and Full PRSPs," March 27, 2002, SM/02/54, REV. 1, http://www.imf.org/external/np/hipc/doc.htm, and March 26, 2002, IDA/SecM2002-174, http://www.worldbank.org/poverty/strategies; and, "Poverty Reduction Strategy Papers-Progress in Implementation," August 8, 2003, SM/03/279, August 14, 2003, IDA/SecM20030468 .
} 
Table 5: HIPCs in the Interim Period: Some Factors Delaying PRSP Preparation

\begin{tabular}{lllll}
\hline $\begin{array}{c}\text { Participatory } \\
\text { Process }\end{array}$ & $\begin{array}{c}\text { Data Collection and } \\
\text { Monitoring }\end{array}$ & $\begin{array}{c}\text { Public Expenditure } \\
\text { Management 1/ }\end{array}$ & $\begin{array}{c}\text { Costing and } \\
\text { Prioritizing }\end{array}$ & Other \\
\hline Cameroon & Chad & The Gambia & The Gambia & Cameroon 2/ \\
Chad & Cameroon & Ghana & Ghana & Madagascar 3/ \\
Ghana & The Gambia & Malawi & Sierra Leone 4/ \\
Malawi & Guinea & Madagascar & Zambia 5/ \\
Senegal & Guyana & & & \\
Sierra Leone & Rwanda & & & \\
Zambia & Zambia & & & \\
\hline
\end{tabular}

Source: PRSP Preparation Status - Country Reports. Excludes The Democratic Republic of Congo.

1/ Includes improving PERs, MTEFs, budget transparency and HIPC relief tracking systems.

2/ Needed more time to prepare the medium to long-term macroeconomic framework.

3/ Change of government.

4/ Shortage of financial and lack of human resource and technical capacity.

5/ Lack of human resource and technical capacity.

constraints facing countries in PRSP design and implementation. Recent PRSPs reveal a greater focus on improving the realism of economic growth projections and the macroeconomic frameworks underpinning PRSPs. ${ }^{23}$ PRSP preparation status reports have helped identify bottlenecks and the need for technical assistance. More generally, PRSPs have increased the focus on public expenditure management although progress in this area remains a challenge. ${ }^{24}$

\section{Looking ahead, a number of countries are well placed to reach their completion} points in 2003 or early 2004. In terms of meeting the conditions related to macroeconomic stability and the one-year satisfactory implementation of a PRSP, twelve countries are either pursuing or making efforts to continue the implementation of IMF-supported macroeconomic programs (Table 6). If these efforts succeed and the countries remain on track, reaching the completion point in either 2003 or early 2004 would be possible provided two other conditions are met: the Joint Staff Assessments report has been discussed at the Boards of the Bank and the Fund, and the countries successfully complete the predefined social and structural conditions. Progress toward implementing the predefined social and structural conditions is discussed further below.

\footnotetext{
${ }^{23}$ See IMF and World Bank, "Poverty Reduction Strategy Papers—Progress in Implementation,” op. cit.

${ }^{24}$ See IMF and World Bank, "Actions to Strengthen the Tracking of Poverty Reducing Spending in HIPCs," March 22, 2002, SM/02/30, REV. 2, http://www.imf.org/external/np/hipc/doc.htm, and March 20, 2002, IDA/SecM200230/2, http://www.worldbank.org/hipc.
} 
Table 6. HIPCs in the Interim Period:

Status of Macroeconomic Policies and PRSP Preparation

(As of July 2003)

\begin{tabular}{|c|c|c|c|}
\hline \multicolumn{2}{|c|}{ Countries On Track With Macroeconomic Policies } & \multicolumn{2}{|c|}{ Countries With Macroeconomic Policies Off Track } \\
\hline PRSP Finalized & Date Plus One Year 1/ & & PRSP Finalized in: \\
\hline Cameroon & Apr-04 & Guinea & Jan-03 \\
\hline Chad & Jun-04 & Honduras & Aug-01 \\
\hline Ghana & Feb-04 & Malawi & Apr-02 \\
\hline Madagascar & Jul-04 & & \\
\hline Ethiopia & Jul-03 & & \\
\hline Gambia, The & Apr-03 & & \\
\hline Guyana & Nov-02 & & \\
\hline Nicaragua & Jul-02 & & \\
\hline Niger & Jan-03 & & \\
\hline Rwanda & May-03 & & \\
\hline Senegal 2/ & Mar-03 & & \\
\hline Zambia & Mar-03 & & \\
\hline \multicolumn{4}{|c|}{ PRSP Not Finalized } \\
\hline Sierra Leone & & Guinea-Bissau & \\
\hline $\begin{array}{l}\text { Democratic Republic of } \\
\text { Congo }\end{array}$ & & São Tomé and Príncipe & \\
\hline
\end{tabular}

Source: IMF Staff estimates.

1/ Date is one year after the submission of the full PRSP. In addition, the Joint Staff Assessments would need to be approved by the Boards of the Bank and Fund.

2/ Senegal is a retroactive case, not subject to the one-year satisfactory implementation requirement. 


\section{Satisfying Social and Structural Completion Point Triggers}

\section{Social and structural completion point triggers support pro-poor growth and} poverty alleviation including a reorientation of public expenditures. One aim of these triggers is to ensure the effectiveness of debt relief through the establishment and strengthening of implementing agencies and public expenditure monitoring mechanisms. Another aim is to ensure the use of savings resulting from HIPC debt relief is used to finance expenditures supporting poverty reduction and growth. ${ }^{25}$ These measures are aligned with the framework of the I-PRSP and pre-defined at the decision point. Policy measures have been supported in the areas of governance, public expenditure management, fiscal transparency, financial restructuring and privatization, health (including HIV/AIDS) and education, and rural and agricultural reform. In some HIPCs, development of a system for the tracking expenditures has also been required.

\section{The enhanced Initiative provides flexibility in applying these triggers. ${ }^{26}$ The}

Executive Boards of the Fund and the Bank make judgments at the completion point as to whether progress on individual triggers is sufficiently satisfactory to indicate that the trigger has been met. In addition, the Board of the Bank can take a broad view of progress across triggers to reach overall conclusions of whether they have been met; the Board of the Fund can grant waivers as necessary where a particular condition has not been met or has been superceded by events, when the thrust of the overall performance is satisfactory. ${ }^{27}$

25. Progress in meeting these triggers varies across countries during the interim period. Although lack of satisfactory progress in meeting these triggers has not been the proximate cause for delay in reaching completion points, implementation has generally been slower than envisaged. In many cases, progress is broadly satisfactory. In eight countries (Ethiopia, Ghana, Guinea, Honduras, Malawi, Rwanda, São Tomé and Príncipe, and Sierra Leone), progress in meeting the structural and social completion point triggers is generally satisfactory or good, although a final determination can be made only at the time of the completion point. In the remaining 11 HIPCs in the interim period no consistent pattern of performance emergesperformance may be strong in several areas but not in others. In many cases, within specific sectors such as health and education, performance on most triggers has been satisfactory but one or more triggers may not have been met or insufficient information is available to make a determination (see Box 2). Difficulties with key triggers could prove to be obstacles to reaching the completion point in the future though they have not been in the past.

\footnotetext{
${ }^{25}$ In this context, the review by the World Bank's Operations Evaluation Department highlighted the importance of focusing on pro-poor growth and balancing such development priorities relative to social expenditures. See World Bank, Operations Evaluation Department, "Debt Relief for the Poorest," op. cit.

${ }^{26}$ See IMF and World Bank, "Modifications to the Heavily Indebted Poor Countries (HIPC) Initiative,” July 23, 1999, EBS/99/138, http://www.imf.org/external/hp/hipc, and July 26, 1999, IDA/SecM99-475, http://www.worldbank.org/hipc.

27 To date the Fund Board has granted waivers to Mauritania and Tanzania.
} 
Box 2: Examples of Structural and Social Completion Point Triggers

Chad: Progress on meeting conditions in the areas of governance, health (including HIV/AIDS), education, and rural infrastructure has been uneven, with continuous deterioration of some indicators in the health sector. Overall, most indicators in the social sectors and in rural development remain far from the target. This could delay the completion point. Corrective actions are being planned within the framework of the preparation of the 2004 program budgets.

Ghana: Triggers have been met in the areas of education and local-government service bill. Progress has also been made toward meeting triggers in the use of budgetary savings, procurement reform, installation of a computer-based financial management system, and electricity and petroleum pricing. Corrective measures will need to be discussed for five pending conditions: (i) full staffing of internal audit functions, (ii) monthly publishing in the government gazette of reports on cash expenditures and commitments by ministry departments and agencies, (iii) development of a district composite budget, (iv) expanding rural water coverage to 46 percent, and (v) raising recurrent health expenditures at district and lower-level governments to 45 percent of the total health budget.

Niger: Most of the completion point triggers in the areas of governance, education, and health have been met. Corrective measures will need to be discussed for five pending conditions: (i) evaluating the impact of public spending on the poor in the health sector; (ii) the completion of a report on impediments to primary school enrollment; (iii) limiting grade 6 repetition rate to at most 15 percent; (iv) adopting a plan to improve the availability of essential drugs in rural health centers; and (v) increasing national immunization rates of children aged 12-24 months for DPT3 to 40 percent. An evaluation of the impact of public spending on the poor also remains to be done.

Source: Annex III.

\section{B. Challenges in Reaching Decision Points}

26. Domestic conflict is a dominant factor in most HIPCs yet to reach the decision point (see Annexes II and III). In most of these countries, continuing domestic conflict or unsettled transitions from post-conflict situations have hampered effective policy implementation and institution building. Last year a socio-political crisis interrupted progress toward reaching the decision point in Côte d'Ivoire. Preparation of a preliminary HIPC document was derailed in the Central African Republic by a resurgence of domestic conflict. Elsewhere, a lack of political consensus on important issues such as revenue sharing (Comoros) or lack of effective implementation of economic and financial policies has been a key impediment in reaching the decision point.

27. In several countries, a period of stabilization has been followed by renewed conflict. As a result, efforts toward stabilizing domestic security conditions and establishing a track record of policy performance have been derailed. In Burundi, the Central African Republic and Côte d'Ivoire, for example, staff monitored programs or PRGF-supported programs were in place or discussions on PRGF-supported programs had commenced but they were aborted as conflict reemerged. Domestic conditions need to stabilize and security conditions need to be maintained before pre-decision point countries can move forward quickly toward the decision point.

\section{Another potential impediment is the settlement of protracted external payments} arrears, including arrears to multilateral creditors. In several HIPCs, such as Liberia, Somalia and Sudan, a concerted international effort would be needed to resolve outstanding arrears. Such an effort appears to be emerging in Sudan (see Annex III). In a special meeting in February 2003 to review arrears clearance arrangements in HIPCs, representatives of multilateral 
development banks endorsed the principle of providing positive or at least non-negative net resource transfers to HIPCs in arrears clearance operations in the context of the HIPC Initiative. They also agreed on a stronger process of early consultation and communication.

\section{The HIPC Initiative is open to all eligible countries that establish a performance} record leading to the decision point by the end of 2004 when the sunset clause takes effect. The sunset clause stems from the 1996 Program of Action, which established a time limit in order to prevent the HIPC Initiative from becoming a permanent facility and to encourage HIPCs to adopt adjustment programs that could be supported by the IMF and IDA. The Boards subsequently agreed to two-year extensions in 1998, 2000, and 2002. Some HIPCs could start establishing a policy performance record before the sunset clause takes effect by the end of 2004, in order to reach the decision point. The approach to engagement in LICUS contained in the World Bank Task Force Report on Low Income Countries Under Stress (LICUS) may be useful in supporting HIPCs that face conflict-related, governance or capacity obstacles to reaching decision points. $^{28}$

\section{OBSERVATIONS ON GOVERNANCE AND DEBT SUSTAINABILITY}

The international community has underscored the importance of good governance to achieving pro-poor growth in HIPCs. The current HIPC framework strongly supports improved governance, especially in strengthening public financial management and is part of a broader framework of international assistance to improve governance in these countries. The Bank and Fund, together with development partners, have organized a series of workshops on debt sustainability in the context of achieving the Millennium Development Goals (MDGs) in lowincome countries, especially HIPCs. Staffs will prepare a joint Board paper by the end of the year that will reflect many of the conclusions reached in these workshops.

\section{A. Governance}

\section{Governance is a key issue in the policy agenda in PRSPs which provide an} overarching country-owned governance strategy that can be supported by the international community. ${ }^{29}$ Governance problems are wide-ranging, but nonetheless, some countries through the PRSP process have made a promising start to address them. PRSPs provide a strategic framework for improved governance and enhance country ownership of these reforms.

\footnotetext{
${ }^{28}$ See World Bank, "World Bank Group Work in Low-Income Countries Under Stress: A Task Force Report," July 8, 2002, SecM2002-0367, http://www.worldbank.org/operations/licus.

${ }^{29}$ Governance is the exercise of economic, political, and administrative authority to manage a country's affairs through formal rules and processes. It comprises mechanisms, processes, and institutions through which citizens and groups articulate their interests, exercise their legal rights, meet their obligations, and mediate their differences. Public sector governance includes government administration, civil service, decentralization, tax administration, legal and judicial reform, anti-corruption, and public expenditure management.
} 
31. Public expenditure management (PEM) measures support efforts to improve governance in HIPCs. PRSPs for HIPCs in many cases reinforce these measures. The IMF and World Bank have supported the PRSP process through periodic assessments of each of these areas. A recent Bank-Fund review found that PEM reforms in HIPCs are increasingly being addressed in PRSPs. The average number of PEM measures rose from eight in 2001 to over 16 in PRSPs produced during 2002-03. Further, the Bank and Fund have had an on-going effort for the past 3 years to strengthen PEM in HIPCs. In February 2002 staff assessments of public expenditure management systems in 24 HIPCs were reported, including development of action plans for improvement. ${ }^{30}$ Of the 24 countries included in the assessment, nine require some upgrading to be able to track poverty-reducing spending satisfactorily, and the remaining fifteen require substantial upgrading. A more recent review examined country progress in implementing action plans of 21 HIPCs to strengthen the capacity to track poverty-reducing expenditures. ${ }^{31}$ The update found that more than three-fourths of measures in the action plans have either been fully implemented or are under implementation.

32. Good governance practices are supported in HIPCs through structural benchmarks in PRGF programs, Bank Poverty Reduction Support Credits and institution-building projects, and in most cases through social and structural completion point triggers. Governance is also an integral part of IDA's performance-based allocation system. Good governance practices (including those related to public expenditure management) are also supported through multiple donor and creditor instruments. Structural completion point triggers have supported governance reforms in HIPCs. For example, completion point triggers have required: (i) Most HIPCs to establish tracking systems to monitor the use of HIPC relief; (ii) Rwanda and Cameroon to implement an integrated financial management information system on a pilot basis; (iii) Establishment and implementation of anti-corruption strategies in Benin, Guinea, Cameroon, and Honduras; (iv) Reform of the public procurement system in Cameroon, Chad, Ghana, Guyana, Guinea-Bissau and Nicaragua; and (v) reforms to Government audit office or national audit standards in Ghana and São Tomé and Príncipe.

\section{Governance is a process requiring continued efforts by HIPCs as well as external} support from the international community. Governance will continue to be a strong focus of the instruments and programs of the Bank, Fund and international community. This focus extends beyond the HIPC Initiative. Staffs will continue to work to strengthen the reporting on governance of HIPCs at the completion point.

\footnotetext{
${ }^{30}$ See IMF and World Bank, "Actions to Strengthen the Tracking of Poverty-Reducing Spending in Heavily Indebted Poor Countries (HIPCs)," March 21, 2002, IMF SM/02/30, http://www.imf.org/external/np/hipc/doc.htm, and March 22, 2002, IDA SecM2002-30/2, http://www.worldbank.org/hipc/hipc-review/hipc-review.html.

${ }^{31}$ See IMF and World Bank, "Update on Implementation of Action Plans to Strengthen Capacity of HIPCs to Track Poverty-Reducing Spending," March 7, 2003, http://www.imf.org/external/np/hipc/doc.htm, and March 7, 2003 IDA/R2003-0043, http://www1.worldbank.org/publicsector/pe/HIPCUpdate.pdf.
} 


\section{B. Debt Sustainability}

34. There is increasing appreciation in the international community of the challenges of mobilizing the financing necessary to help achieve the MDGs in low-income countries while ensuring long-term debt sustainability. The global economic downturn, declines in many international commodity prices, and additional debt accumulation have raised debt-burden indicators in some low-income countries, including HIPCs. This has occurred, regardless of where HIPCs have been in the debt-relief process. At the same time, there is a recognized tension between the need to finance the MDGs in these countries and the need to avoid accumulating unsustainable external debt. These developments have led the Fund, the Bank, and other members of the international community to initiate a process to assess the criteria and standards for evaluating debt sustainability as well as the policy implications for the countries themselves and for the international community.

35. There is also recognition by the international community that debt relief provided by the HIPC initiative can reduce the debt burden significantly but not guarantee debt sustainability. For debt to remain at sustainable levels requires continued efforts by creditors and debtors to ensure an appropriate level and concessionality of new resource flows, including through strengthening HIPC debt management capacity. Moreover, translating debt reduction into poverty reduction will require continued measures to use fiscal savings towards poverty-reduction and growth within the PRSP framework (See Box 3). ${ }^{32}$

\section{The Boards of the Bank and Fund have asked staffs to suggest a way forward in} developing a framework for debt sustainability and development financing. Bank and Fund staffs have consulted through joint workshops with French, German, and Commonwealth Secretariat partners to explore long-term debt sustainability issues in low-income countries. ${ }^{33}$ The results of these workshops and analysis have been used as inputs for briefings to the IMF and World Bank Boards. A workshop sponsored by the Bank and Fund will be held in Washington on September 11-12 and a multilateral development bank workshop is scheduled for late October. In December 2003 a joint paper for the Bank and Fund Boards will present proposals on policy and operational options on how to approach long-term debt sustainability in low-income countries.

\footnotetext{
${ }^{32}$ The World Bank Operations Evaluation Department review suggests that the focus of development priorities should be more on pro-poor growth relative to social expenditures. See World Bank Operations Evaluation Department, "Debt Relief for the Poorest," op. cit.

33 The French Development Agency organized a workshop in Paris May 14, 2003. The German agency InWEnt organized a workshop in Berlin May 19-20, 2003. The Commonwealth Secretariat organized a workshop in Accra, Ghana, June 9-10, 2003.
} 
Box 3: World Bank Operations Evaluation Department Review of the HIPC Initiative

In February 2003, the World Bank Operations Evaluation Department reviewed the HIPC Initiative in a report entitled "Debt Relief for the Poorest - An OED Review of the HIPC Initiative." The report found the HIPC Initiative highly relevant in reducing the excessive debt burden of qualifying countries, noting that, "relative to past efforts, it is more concerted across creditors and more comprehensive in its attempt to reduce the high external debt — including, for the first time, multilateral debt — of many of the poorest countries. It has made the processes surrounding the sovereign debt regime more open and accountable." (Executive Summary, p. xii) At the same time, the OED review found that the legitimizing process that helped make the initiative a reality also expanded its objectives - including not just a 'permanent' exit from debt rescheduling but also promotion of growth, and releasing of resources for social expenditures targeted at poverty reduction (See Forward, p. ix). The HIPC Initiative is a limited instrument, according to the OED review, and it now runs the risk of promising more than it can deliver by itself. Instead, the OED argues that the HIPC Initiative is "an important but small part of the overall development assistance framework. Having provided the HIPCs with an opportunity for a 'fresh start,' the international community still faces a challenge in helping these countries set out on a sustainable path for growth and poverty-reduction. This requires actions by the HIPC governments to adopt sound policy frameworks and a balanced development strategy. It also requires actions by the international community to assist the countries to enhance their exports and build needed institutional capacities" (Forward, p. ix).

The report therefore recommends the Bank to: (i) clarify the purposes and objectives of the Initiative, ensure that its design is consistent with these objectives, and both the objectives and how they are to be achieved be clearly communicated to the global community; (ii) improve the transparency of the methodology and economic models underlying the debt projections and the realism of economic growth forecasts in debt sustainability analyses; (iii) maintain the standards for policy performance, and when the established criteria are to be relaxed there should be a clear and transparent rationale to ensure that the risks to achieving and maintaining the Initiative's objectives are minimized; and (iv) focus more on pro-poor growth and provide a better balance among development priorities relative to the current focus on social expenditures.

Work is underway to implement these recommendations by: (i) continuing to work with relevant stakeholders to clarify and communicate the objectives of the HIPC Initiative by noting that reductions in the debt stock through the Initiative was expected to contribute to a more comprehensive development effort but not to supplant it; (ii) working to improve the realism of growth projections and to apply stress tests that assess risks to baseline scenarios; (iii) continuing to ensure that policy performance standards are maintained; and (iv) assisting HIPCs ensure that the use of savings of debt relief are allocated to expenditures for pro-poor growth consistent with the PRSP framework (See Annex K).

Source: World Bank, Operations Evaluation Department, "Debt Relief for the Poorest,” op. cit.

\section{Key issues being reviewed are the definition of the debt burden and when it is} sustainable, the impact of volatility and shocks, and the role of country-specific policies and circumstances. There is agreement on the need to base sustainability assessments on a range of indicators, to monitor and assess the level and composition of both domestic and external public debt, and to adopt a country-specific approach. There has been some debate over how to treat non-guaranteed state enterprise debt in these calculations. There is also recognition of the importance of economic volatility and the prevalence of exogenous shocks in low-income countries. Staffs are evaluating the prevalence of volatility, the severity and frequency of shocks, economic growth and impact on debt sustainability of each. Even more important, staffs are examining how grants and other financing mechanisms could potentially be made more countercyclical, more predictable and better coordinated to address volatility. Staffs are also reviewing concessional lending instruments and strategies to help manage shocks. Finally, staffs are exploring how country-specific policies and circumstances have affected growth and debt sustainability. 


\section{Creditor Participation}

\section{A. Multilateral Creditors: Costs, Commitments and Delivery}

38. Costs attributable to multilateral creditors are little changed over the past year, while participation has increased with almost all creditors participating. In NPV terms, multilateral creditors accounted for US\$19.0 billion, or 48 percent of total HIPC costs for 34 countries of US\$39.4 billion (Appendix Table 8). This represents an increase of US $\$ 0.1$ billion in $2001 \mathrm{NPV}$ terms. Twenty-three of 30 multilateral creditors have indicated their intention to participate in the Initiative, representing more than 99 percent of the total debt relief required. In October 2002, the East African Development Bank agreed to participate in the HIPC Initiative and the Arab Monetary Fund reconfirmed its participation in early 2003. The large multilateral creditors, including the IDA, the IMF, the African Development Bank (AfDB), the InterAmerican Development Bank (IDB), the European Investment Bank/European Union (EIB/EU), and the Central American Bank for Economic Integration (CABEI) are providing relief to most countries in the interim period. So far multilateral creditors have delivered more than US $\$ 3.8$ billion in relief.

\section{The total cost to the World Bank Group remains largely unchanged since}

September 2002. The cost of the Initiative for 34 countries is estimated to be US\$8.7 billion in 2002 NPV terms. The 27 HIPCs that have reached their decision points account for US\$7.7 billion (NPV) of this figure (US\$12.4 billion in nominal terms) (Appendix Tables 9 and 10). ${ }^{34}$ As of the end of May 2003, the World Bank had delivered a total of US\$2.5 billion in nominal terms to these 27 HIPCs. Of this, US\$101 million in nominal terms is relief to Cameroon and Honduras, two IDA-only countries with significant IBRD debt outstanding. IDA debt relief under the HIPC Initiative to the 27 decision point HIPCs is projected to total more than US\$400 million in 2003 and the average for the period 2003-09 is estimated to exceed US\$500 million. Given average annual World Bank Group net transfers of US\$1.3 billion to these 27 countries during 1998-2002, the HIPC Initiative could, with sustained IDA flows, increase IDA's net transfers to HIPCs by more than 40 percent. IDA is providing interim relief to 17 of 19 countries in the interim period. ${ }^{35}$ It also delivers irrevocable debt relief to all eight countries that reached the completion point under the enhanced Initiative.

40. IDA's financing needs have been met through the IDA-13 period. The HIPC Trust Fund has two components. The first is the management of funds to reimburse IDA for HIPC debt relief. The Bank has pledged to provide US\$2.15 billion (NPV) or US\$2.4 billion (nominal) in IBRD net income transfers to the HIPC Trust Fund to reimburse IDA for HIPC debt relief. To date, US\$1.64 billion of such transfers has been approved. Covering IDA's costs through IDA13 would require estimated annual transfers of US\$240 million per year on average for this year and the following two years. This level of estimated transfers would fully utilize this pledge. Donors have reaffirmed that the cost of IDA's debt relief, estimated to exceed US\$500 million

\footnotetext{
34 The figures include debt relief on interest payments related to stock operations.

${ }^{35}$ In Cameroon and Honduras, the cumulative limit of one-third of the total NPV of relief has been reached. Senegal will reach the cumulative limit in September 2003 and The Gambia will do so in December 2004.
} 
for a decade or more beyond IDA-13, should not be permitted to compromise IDA's resources. They agreed during the IDA-13 discussions that the financing of IDA's HIPC debt relief costs would be addressed in 2004 at back-to-back meetings with the IDA-14 replenishment discussions.

\section{IDA debt relief grants and credits are being used to finance debt relief for} Cameroon and Honduras because IBRD net income transfers to the HIPC Trust Fund cannot be used to provide debt relief for these countries which have substantial levels of outstanding IBRD debt. ${ }^{36}$ These grants and loans were estimated to total about US $\$ 333$ million at the time of their decision points. Funding for this debt relief was provided as part of the IDA-13 funding arrangement.

\section{Additional contributions have been pledged by donors to the IDA-administered} HIPC Trust Fund for Regional and Subregional Creditors. The second component of the HIPC Trust Fund supports the provision of debt relief to eligible HIPCs by regional and subregional multilateral creditors using donors' funds (Appendix Table 13). In October 2002 donors made additional pledges of about US\$850 million to the HIPC Trust Fund to support the debt relief to be provided by eligible creditors. This brought total pledges to about US\$3.4 billion. Several uncertainties could affect future debt relief costs and corresponding HIPC Trust Fund financing requirements. They include the timing and level of debt relief that will be required for countries that have not yet reached their decision points, the level of topping up that may be approved and the potential eligibility of countries not currently included in the costing estimates such as Sudan. Paid-in contributions reached about US\$2.6 billion on June 30, 2003. HIPC Trust Fund resources have helped finance the participation of the AfDB US\$1,010.2 million, the IDB US\$84.3 million, the CABEI US\$81.9 million, the Corporación Andina de Fomento (CAF) US\$55.6 million, Banque Ouest Africaine de Developpement (BOAD) US\$24.9 million, the Fund for the Financial Development of the River Plate Basin (FONPLATA) US\$18.7 million, the Nordic Development Fund (NDF) US\$12.8 million, the International Fund for Agricultural Development (IFAD) US\$9.7 million, and the Caricom Multilateral Clearing Facility (CMCF) US\$2.5 million.

\section{The cost to the IMF for 34 countries is estimated at US\$2.9 billion in 2002 NPV terms, little changed from previous estimates. Of this amount, US\$2.7 billion in NPV terms have already been committed to 27 decision point countries, which is equivalent to SDR 1.8 billion on a cash basis, of which SDR 1.1 billion has been disbursed (Appendix Tables 11 and 12). Based on current projections and the current methodology for calculating the IMF's share of HIPC Initiative topping up assistance, HIPC grant resources are estimated to be sufficient. ${ }^{37}$}

\footnotetext{
${ }^{36}$ Côte d'Ivoire was also identified as a country with substantial IBRD exposure where this modality would be applied. Because Côte d'Ivoire has not reached the decision point under the enhanced HIPC Initiative, nor reached the completion point under the original HIPC Initiative, the Bank has not yet provided any relief under the HIPC Initiative.

${ }^{37}$ The implications for financing of the topping up assistance for the IMF are discussed in detail in IMF "Update on the Financing of PRGF and HIPC Operations and the Subsidization of Post-Conflict Emergency Assistance," March 21, 2003, SM/03/100, http://www.imf.org/external/np/tre/pledge/2003/023003/pdf.
} 
44. The IMF may provide interim assistance to HIPCs. IMF interim assistance is provided for a period of up 12 months at a time; additional tranches of interim assistance can be provided if the conditions for interim assistance are met (in particular, performance under the PRGF arrangement is satisfactory and financing assurance from other creditors are in place). In 2002, prolonged program interruptions prevented Guinea-Bissau, Honduras, and Malawi from receiving IMF interim assistance throughout the year, whereas the remaining HIPCs that had not yet reached the completion point benefited from interim assistance.

45. The cost to the African Development Bank (AfDB) of the 23 African countries that have reached the decision point is US\$2.8 billion in $2002 \mathrm{NPV}$ terms. The AfDB has committed US\$1.6 billion in NPV terms at the decision point (US\$2.2 billion in nominal terms) to the 22 countries that have reached their decision points in the AfDB, of which US\$320 million (NPV) will be contributed from internal resources. ${ }^{38}$ As of the end of 2002, the AfDB had delivered US\$493 million in relief to 22 countries under the HIPC Initiative. It is delivering relief to 14 of 15 HIPCs in Africa in the interim period. In Senegal, the AfDB delivered its cumulative limit of 40 percent of the total NPV during the interim period; Senegal is therefore not receiving additional interim relief. It is anticipated that Cameroon, The Gambia, Guinea, Madagascar, and Zambia will also reach their cumulative limits for interim relief over the next six months.

46. The cost to the InterAmerican Development Bank (IDB) of the four HIPCs in the region is US\$1.3 billion in 2002 NPV terms. Between 1998 and the end of 2002, IDB delivered US\$111.3 million in nominal terms under the original framework and US\$150.5 million under the enhanced framework. IDB is delivering interim relief to Guyana and Nicaragua but stopped providing interim relief to Honduras in 2002 when one-third of the total NPV of relief required had been delivered.

47. The 26 other multilateral creditors bear costs of US\$2.8 billion in 2002 NPV terms, US\$2.4 billion of which goes to the 27 decision point countries (Appendix Table 8). Seven small creditors have not indicated a willingness to participate in the Initiative due mainly to financial constraints. Providing HIPC relief has posed a substantial challenge to some multilateral creditors, including some that are participating fully. Such creditors have found it difficult to reconcile their interest in participating in an international initiative with the need to maintain their financial integrity. In some cases, multilateral creditors have also had difficulties ensuring that the amount of relief provided is sufficient to meet the NPV reduction required.

\section{B. Official Bilateral Creditors: Costs, Commitments and Delivery}

48. Since September 2002, Paris Club creditors have agreed to stock-of-debt operations on Cologne terms for Benin and Mali at their completion points and flow reschedulings for Nicaragua and The Gambia (Cologne terms), and the Democratic Republic of Congo (Naples terms). The flow rescheduling for the Democratic Republic of Congo was instrumental in clearing arrears to external creditors. In addition, many Paris Club creditors offered terms for

\footnotetext{
${ }^{38}$ The Executive Board of the AfDB has not yet met to decide on its modality for delivering HIPC assistance to the Democratic Republic of Congo.
} 
the arrears clearance that went beyond Naples terms. The Paris Club agreed to consider toppingup the Naples flow rescheduling amounts to Cologne terms once the Democratic Republic of Congo reaches the decision point, which would reduce the country's debt-service obligations by another 70 percent.

49. Most of the costs attributable to official bilateral creditors are borne by members of the Paris Club. Paris Club creditors account for US\$15.2 billion, or 39 percent of the total HIPC costs of US $\$ 39.4$ billion for 34 countries in 2002 NPV terms. All Paris Club creditors have committed to deliver their share of HIPC relief to the 27 countries that have reached the decision point totaling about US\$12.5 billion in 2002 NPV terms (Appendix Tables 14 and 15). Many Paris Club creditors are providing interim relief and relief over and above that required under the HIPC Initiative (Appendix Table 16).

\section{The participation of non-Paris Club bilateral creditors has improved since}

September 2002. The fifty-one non-Paris Club official bilateral creditors account for US\$3.4 billion of HIPC relief costs to 34 countries in 2002 NPV terms (Appendix Tables 17 and 18 ), of which the costs for the 27 decision point countries represent US\$3.3 billion (Appendix Table 8). In September 2002 Libya agreed to fully participate in the Initiative and deliver US\$225 million (in 2002 NPV terms) in HIPC relief to 16 countries. ${ }^{39}$ In June 2003 India announced its decision to write off all claims on HIPCs, thereby benefiting Ghana, Guyana, Mozambique, Nicaragua, Tanzania, Uganda, and Zambia.

51. Delivery of relief by non-Paris Club official bilateral creditors can be fully measured only after their debtors reach the completion point. Because non-Paris Club bilateral creditors typically deliver relief only after the completion point, delivery of relief becomes an issue only once countries to which they have outstanding loans reach the completion point. Of the 51 nonParis Club bilateral creditors, 13 have indicated commitments to deliver full debt relief under the HIPC Initiative framework and 14 have made commitments to deliver HIPC relief on some but not all claims on HIPCs. Twenty four non-Paris Club creditor countries representing about 21 percent of the total cost attributable to this group have not yet agreed to deliver HIPC relief.

\section{In March 2003 the Boards of the Bank and the Fund reviewed measures to provide} relief by HIPC creditors to HIPC debtors. ${ }^{40}$ Based on the input received from the Board discussion staffs have been working with bilateral creditors and donors to further explore options to resolve this issue.

\footnotetext{
${ }^{39}$ Libya has also agreed to participate in the enhanced HIPC Initiative. Staff estime that traditional debt relief, i.e. a stock-of-debt operation on Naples terms, could cost around US\$900 million in 2002 NPV terms.

${ }^{40}$ See IMF and World Bank, "Enhanced HIPC Initiative_Creditor Participation Issues,” February 28, 2003, SM/03/82, http://www.imf.org/external and February 28, 2003, IDA/SecM2003-092, http://www.worldbank.org/hipc.
} 


\section{Commercial Creditors and Creditor Litigation}

53. The size of commercial debt owed by HIPCs has already been substantially reduced as a result of the Debt Reduction Facility for IDA-only Countries. HIPC relief from commercial creditors required under the Initiative accounts for about 5 percent of HIPC relief. In some HIPCs, however, commercial creditors account for a significant proportion of outstanding debt. Encouraging commercial creditors to deliver HIPC relief is complicated by their limited interaction with the World Bank and the IMF. As discussed in the September 2002 report, although the claims of commercial creditors are small in NPV terms, they are nevertheless a cause of concern because debtors fear the impact of litigation and impairment of creditor-debtor relationships.

\section{In a number of cases commercial creditors and some non-Paris Club bilateral} creditors have resorted to threats of or actual litigation as a means of debt recovery. The Boards of the IMF and World Bank asked staffs to further monitor creditor litigation against HIPCs. Staffs have conducted a follow-up on the August 2002 survey of the 28 HIPC governments for countries that have had Board documents prepared. Table 7 below was updated based on information provided by 20 respondents. Of 28 HIPCs that have had Board documents prepared, 12 indicated that they were not facing any lawsuits. Nine responded that they were facing litigation on credits held by commercial creditors and Iraq. Although in many cases debtors have not remitted payments after creditors have received judgments, in some cases debtors have made payments in excess of that required if the creditor had provided HIPC relief. Pending litigation and outstanding court judgments also prevent HIPCs from regularizing financial relationships with the international community. 
Table 7. Creditors Involved in Litigation against HIPCs

\begin{tabular}{|c|c|c|c|c|c|}
\hline Creditor 1/ & $\begin{array}{l}\text { Domicile of } \\
\text { Creditor }\end{array}$ & HIPC Debtor & $\begin{array}{l}\text { Original Claim } \\
\text { 2/ (million of } \\
\text { U.S. dollars) } \\
\end{array}$ & Status of Legal Action & $\begin{array}{l}\text { Judgment for } \\
\text { Creditor (millions } \\
\text { of U.S. dollars) } \\
\end{array}$ \\
\hline Salah Turkmani & -- & Bolivia & 0.3 & Pending. & \\
\hline Winslow Bank & Bahamas & Cameroon & 8.9 & $\begin{array}{l}\text { Action instituted by Cameroon to appeal } \\
\text { lower court ruling. }\end{array}$ & \\
\hline $\begin{array}{l}\text { Del Favaro Spa } \\
\qquad \text { Sub-total }\end{array}$ & Italy & Cameroon & 9.2 & -- & \\
\hline Red Mountain & U.S. & $\begin{array}{l}\text { Congo, Dem. } \\
\text { Rep. of }\end{array}$ & 8.6 & Resolved. & 25.4 \\
\hline $\begin{array}{l}\text { ENERGOINVEST } \\
\qquad \text { Sub-total }\end{array}$ & -- & $\begin{array}{l}\text { Congo, Dem. } \\
\text { Rep. of }\end{array}$ & $\begin{array}{l}30.2 \\
38.8\end{array}$ & $\begin{array}{l}\text { Judgment issued by International Court of } \\
\text { Arbitration in Paris. }\end{array}$ & \\
\hline Yugoimport & $\begin{array}{l}\text { Former SFR } \\
\text { Yugoslavia }\end{array}$ & Ethiopia & 122.7 & -- & \\
\hline Sub-total & Bulgaria & Ethiopia & $\begin{array}{r}8.7 \\
131.4\end{array}$ & -- & \\
\hline Laboratorios Baco & Argentina & Honduras & 3.5 & Pending. & \\
\hline $\begin{array}{l}\text { LNC Investments } \\
\text { GP Hemisphere Associates } \\
\text { Van Eck Emerging Markets } \\
\qquad \text { Sub-total }\end{array}$ & $\begin{array}{l}\text { U.S. } \\
-- \\
\text { U.S. }\end{array}$ & $\begin{array}{l}\text { Nicaragua } \\
\text { Nicaragua } \\
\text { Nicaragua }\end{array}$ & $\begin{array}{l}26.3 \\
30.9 \\
13.0 \\
70.2\end{array}$ & $\begin{array}{l}\text { Judgment pronounced. } \\
\text { Judgment pronounced. } \\
\text { Judgment pronounced. }\end{array}$ & $\begin{array}{r}87.1 \\
126.0 \\
62.5 \\
275.6\end{array}$ \\
\hline $\begin{array}{l}\text { Banque Belgolaise } \\
\text { Exim Bank } \\
\qquad \text { Sub-total }\end{array}$ & $\begin{array}{l}\text { France } \\
\text { Taiwan, Province of } \\
\text { China }\end{array}$ & $\begin{array}{l}\text { Niger } 3 / \\
\text { Niger } 3 /\end{array}$ & $\begin{array}{r}4.2 \\
60.0 \\
64.2\end{array}$ & $\begin{array}{l}\text { Legal action in process. } \\
\text { Judgement to pay. }\end{array}$ & 72.3 \\
\hline J\&S Franklin Ltd. & United Kingdom & Sierra Leone & 1.2 & $\begin{array}{l}\text { Action instituted in the High Court of } \\
\text { England; independent of court action, } \\
\text { Sierra Leone has paid US } \$ 1.7 \text { million. }\end{array}$ & \\
\hline UMARCO & France & Sierra Leone & 0.6 & $\begin{array}{l}\text { Action instituted in the High Court of } \\
\text { England; independent of court action, } \\
\text { Sierra Leone has paid US } \$ 0.1 \text { million. }\end{array}$ & \\
\hline $\begin{array}{l}\text { Executive Outcome, International } \\
\text { Inc. }\end{array}$ & United States & Sierra Leone & 19.5 & $\begin{array}{l}\text { Action instituted in the High Court of } \\
\text { England; independent of court action, } \\
\text { Sierra Leone has paid US } \$ 0.7 \text { million. }\end{array}$ & \\
\hline Chatelet Investment Ltd.. & Sierra Leone & Sierra Leone & 0.4 & $\begin{array}{l}\text { Action instituted in the High Court of } \\
\text { England. }\end{array}$ & \\
\hline Industrie Biscotti & Italy & Sierra Leone & 5.3 & $\begin{array}{l}\text { Action instituted in the High Court of } \\
\text { England. }\end{array}$ & \\
\hline Scancem International & Norway & Sierra Leone & 3.7 & $\begin{array}{l}\text { Action instituted in the High Court of } \\
\text { England; independent of court action, } \\
\text { Sierra Leone has paid US\$ } 0.6 \text { million. }\end{array}$ & \\
\hline Sub-total & & & 30.7 & & \\
\hline Banco Arabe Espanol & Spain & Uganda & 1.0 & Judgment to pay. & 2.7 \\
\hline Transroad Ltd. & United Kingdom & Uganda & 5.6 & Resolved & 9.4 \\
\hline $\begin{array}{l}\text { Industry of Construction Machinery } \\
\text { and Equipment }\end{array}$ & $\begin{array}{l}\text { Former SFR } \\
\text { Yugoslavia }\end{array}$ & Uganda & 8.4 & Resolved & 8.9 \\
\hline Sours Fab Famous Rz Promet & $\begin{array}{l}\text { Former SFR } \\
\text { Yugoslavia }\end{array}$ & Uganda & 1.4 & Resolved & 1.4 \\
\hline $\begin{array}{l}\text { Iraq Fund For External Development } \\
\text { Shelter Afrique }\end{array}$ & $\begin{array}{l}\text { Iraq } \\
\text { Kenya }\end{array}$ & $\begin{array}{l}\text { Uganda } \\
\text { Uganda }\end{array}$ & $\begin{array}{l}4.6 \\
0.9\end{array}$ & $\begin{array}{l}\text { Appeal in progress. } \\
\text { Out of court settlement. }\end{array}$ & $\begin{array}{l}6.4 \\
0.1\end{array}$ \\
\hline Sub-total & & & 21.9 & & 28.9 \\
\hline Total & & & 370.1 & & 402.2 \\
\hline
\end{tabular}

Source : HIPC country authorities

The following exchange rates were used in the cases where amounts were not given in US dollars; 1 Euro $=\$ 1.134 \mathrm{USD} ; 1 \mathrm{CHF}=\$ 0.7271 \mathrm{USD}$.

The following 12 countries have reported to have no creditor lawsuits: Benin, Chad, Cote d'Ivoire, Ghana, Guyana, Madagascar, Malawi, Mauritania, Mali, Rwanda, São Tome \& Príncipe, and Tanzania.

Note: The following 8 countries have not provided updated information since September, 2002: Burkina Faso, Gambia, Guinea, Guinea-Bissau, Mozambique, Niger, Senegal, and Zambia.

1/ Either original creditor or holder of current claim.

2/ Excludes accumulated interest and charges.

3/ Data obtained from September 2002, Status of Implementation Report, Table 8.

-- Not available. 


\section{ISSUES FOR DISCUSSION}

55. Progress in reaching the completion point. Do Directors agree that although interim period HIPCs are taking a longer time than envisaged to reach the completion points, attaining macroeconomic stability, satisfactorily implementing PRSPs and meeting other social and structural completion point triggers, are nevertheless critical towards realizing the objectives of the HIPC Initiative? Do Directors have suggestions on how staff could work with the authorities to: (i) facilitate the completion of a full PRSP in the few HIPCs that have yet to do so; (ii) help bring macroeconomic programs back on track; and (iii) help satisfy the remaining social and structural completion point triggers?

56. Decision point eligibility. Do Directors agree that while several countries could establish a track record before the sunset clause takes effect at the end of 2004, that substantial challenges remain in arriving at the decision point, notably the need to stabilize security conditions and to resolve protracted arrears?

57. Governance. Do Directors agree that the emphasis on governance under the HIPC Initiative is appropriate and complements other instruments that are supportive of good governance in HIPCs? Do Directors agree that good governance practices require the concerted and continued efforts of country authorities in addition to the IMF and World Bank and the international community? 


\section{Country Coverage, Data Sources, and Assumptions for the HIPC Costing Exercise}

\section{Country Coverage}

- The costing analysis is based on 42 HIPCs: Angola, Benin, Bolivia, Burkina Faso, Burundi, Cameroon, the Central African Republic, Chad, Comoros, Democratic Republic of Congo, Republic of Congo, Côte d'Ivoire, Ethiopia, The Gambia, Ghana, Guinea, Guinea-Bissau, Guyana, Honduras, Kenya, Lao PDR, Liberia, Madagascar, Malawi, Mali, Mauritania, Mozambique, Myanmar, Nicaragua, Niger, Rwanda, São Tomé and Príncipe, Senegal, Sierra Leone, Somalia, Sudan, Tanzania, Togo, Uganda, Vietnam, Yemen, and Zambia.

- Lao PDR was excluded from the costing exercise because reliable debt data were not available.

- Yemen was excluded from the costing exercise because its debt levels were found to be sustainable after traditional debt relief, based on the latest debt sustainability analysis. Angola, Kenya, and Vietnam were excluded because their debt levels are expected to be sustainable after application of traditional debt-relief mechanisms.

- As in the past, Liberia, Somalia, and Sudan were excluded because of weaknesses in the data and or the uncertainty over the time required to resolve their arrears problems, and hence, the timing of the decision point.

\section{Data Sources}

- Enhanced decision/completion point documents have been presented to the Boards of the Bank and the Fund for the following 27 countries: Benin, Bolivia, Burkina Faso, Cameroon, Chad, the Democratic Republic of Congo, Ethiopia, The Gambia, Ghana, Guinea, GuineaBissau, Guyana, Honduras, Madagascar, Malawi, Mali, Mauritania, Mozambique, Nicaragua, Niger, Rwanda, São Tomé and Príncipe, Senegal, Sierra Leone, Tanzania, Uganda, and Zambia.

- Recently collected debt figures were used to update the potential cost estimates for Mali and the Democratic Republic of Congo.

\section{Assumptions for the HIPC Costing Exercise}

- Calculations of total costs include costs under the original and enhanced HIPC Initiative frameworks, including assistance that has already been delivered.

- Before becoming eligible for assistance under the enhanced HIPC Initiative, countries must make full use of traditional debt-relief mechanisms (i.e., a stock-of-debt operation that provides a 67 percent reduction in the NPV of eligible debt from the Paris Club and 
comparable treatment by non-Paris Club bilateral and commercial creditors). Cost estimates are based on data after full use of traditional debt-relief mechanisms.

- All eligible countries are assumed to request assistance under the enhanced HIPC Initiative.

- Each country-specific Debt Sustainability Analysis (DSA) is based on macroeconomic assumptions about exports and fiscal revenues developed by Bank and Fund staffs in consultation with country authorities.

- The total cost of assistance for Burkina Faso includes topping up of debt relief (US\$129 million in $2001 \mathrm{NPV}$ terms), assumed to have been delivered the same year it reached its completion point (2002).

\section{Update of Cost Estimates in Net Present Value Terms}

- The cost of HIPC assistance is calculated in NPV terms at the time of the decision point. This cost was increased each year after the decision point year by a factor that is estimated as the average interest rate applicable for relief to be committed. This rate was estimated as 6.0 percent for 2000 and 2001. In the costing exercise for the end of 2002, this factor was adjusted from 6.0 percent to 5.45 percent for 2000 and 2001 and a 5.45 percent rate was applied to increase costs from the end of 2001 to the end of 2002 . The 5.45 percent rate corresponds to the implicit long-term interest rate of currencies that comprise the SDR for the 36 monthly periods from end-1999 to end-2002 $2^{41}$. It was calculated as a weighted average of the average Commercial Interest Reference Rate (CIRR) for the period 2000-02, weighted by the participation of the currencies in the SDR basket.

- The effect of the change in the rate applied to increase costs from the end of 2001 to the end of 2002 is small, reducing costs in 2002 NPV terms by about US\$230 million.

\footnotetext{
${ }^{41}$ The currency composition of the SDR was used as a proxy of the currency composition of the assistance under the HIPC Initiative.
} 
Annex II. HIPC Initiative: Progress in Implementation by Country Status as of July 2003

\begin{tabular}{|c|c|c|c|c|}
\hline Country & $\begin{array}{c}\text { Progress in development and implementation of } \\
\text { PRSP }\end{array}$ & Performance under PRGF supported programs & $\begin{array}{c}\text { Actual/ } \\
\text { Expected DP } \\
\text { Date 1/ }\end{array}$ & $\begin{array}{c}\text { Actual/ } \\
\text { Expected CP } \\
\text { Date 1/2/ }\end{array}$ \\
\hline \multicolumn{5}{|c|}{ Countries that have already reached the Completion Point } \\
\hline Benin 3/ & The PRSP was finalized in December 2002. & $\begin{array}{l}\text { Macroeconomic performance was strong and broadly in line } \\
\text { with the PRGF-supported program established for } 2002 \\
\text { consequently the fourth review was completed in March } 2003 \text {. }\end{array}$ & Jul-00 & Mar-03 \\
\hline Bolivia 3/ & $\begin{array}{l}\text { Preparations of the 1st progress report of the PRSP } \\
\text { are underway. The final report is expected in mid- } \\
\text { August. }\end{array}$ & $\begin{array}{l}\text { A review of the Stand By Arrangement (SBA) negotiated in } \\
\text { February } 2003 \text { was approved by the IMF Board in July. The } \\
\text { SBA may be replaced by a PRGF later in the year. }\end{array}$ & Jan-00 & May-01 \\
\hline Burkina Faso 3/ & $\begin{array}{l}\text { The 2nd progress report of the PRSP was reviewed } \\
\text { in November } 2002\end{array}$ & $\begin{array}{l}\text { The 6th review under PRGF was completed in November } \\
\text { 2002. A new PRGF arrangement was approved in June } 2003 \text {. }\end{array}$ & Jul-00 & Apr-02 \\
\hline Mali 3/4/ & $\begin{array}{l}\text { The full PRSP was endorsed by the IMF Board in } \\
\text { February } 2003 \text { and by the Bank Board in early } \\
\text { March } 2003 \text {. }\end{array}$ & $\begin{array}{l}\text { The } 6 \text { th and final PRGF review was completed. The } \\
\text { authorities have indicated an interest in a successor PRGF } \\
\text { arrangement. }\end{array}$ & Sep-00 & Mar-03 \\
\hline Mauritania & $\begin{array}{l}\text { The 1st Progress Report of PRSP was endorsed by } \\
\text { Boards in June 2002. The 2nd PRSP progress report } \\
\text { was endorsed by Boards in July } 2003 \text {. }\end{array}$ & $\begin{array}{l}\text { A new PRGF arrangement was approved by the Fund Board } \\
\text { in July } 2003 \text {. }\end{array}$ & Mar-00 & Jun-02 \\
\hline Mozambique 3/ & $\begin{array}{l}\text { The first PRSP progress report was prepared in } \\
\text { February 2003. A JSA was presented to the Board } \\
\text { in June 2003. }\end{array}$ & $\begin{array}{l}\text { The 5th review of the PRGF arrangement was completed in } \\
\text { June } 2003 \text {. }\end{array}$ & Apr-00 & Sep-01 \\
\hline Tanzania & $\begin{array}{l}\text { The PRSP enjoys broad support and ownership. } \\
\text { The 2nd progress report on PRSP implementaton } \\
\text { was issued in May } 2003 \text {. }\end{array}$ & $\begin{array}{l}\text { The 6th and final PRGF review was completed in January } \\
2003 \text {, and a new low-access PRGF arrangement was approved } \\
\text { in July } 2003 \text {. }\end{array}$ & Apr-00 & Dec-01 \\
\hline Uganda 3/ & $\begin{array}{l}\text { The 2nd progress report on the PRSP } \\
\text { implementation was issued in July } 2002 \text { and the } \\
\text { third is scheduled to be presented to the Board of } \\
\text { the Bank in September } 2003 \text {. A revision of the } \\
\text { PRSP is scheduled for late } 2003 \text { or early } 2004 \text {. }\end{array}$ & $\begin{array}{l}\text { A new PRGF was approved in September } 2002 \text {. The 1st } \\
\text { review was succesfully completed in June } 2003 \text {. }\end{array}$ & Mar-00 & May-00 \\
\hline \multicolumn{5}{|c|}{ Countries between Decision and Completion Point } \\
\hline Cameroon & $\begin{array}{l}\text { The full PRSP was submitted to the Bank and Fund } \\
\text { in April } 2003 \text { and endorsed by the two Boards at } \\
\text { end-July } 2003 \text {. }\end{array}$ & $\begin{array}{l}\text { The 3rd review was completed in September } 2002 \text {. } \\
\text { Completion of the 4th review of the PRGF arrangement by } \\
\text { the Fund Executive Board is still pending, while Fund staff } \\
\text { seeks clarification on the fiscal outturn in the first months of } \\
2003 \text {. }\end{array}$ & Oct- 00 & Q2 2004 \\
\hline Chad & $\begin{array}{l}\text { The full PRSP was delayed because of the time } \\
\text { needed to conduct the participatory approach and } \\
\text { prepare the macroeconomic framework.It was } \\
\text { finalized and submitted to the Fund and Bank in } \\
\text { June } 2003 \text {. }\end{array}$ & $\begin{array}{l}\text { Performance under PRGF has been satisfactory since } 2000 \text {. } \\
\text { The } 5 \text { th review under the PRGF arrangement was completed } \\
\text { in July } 2003 \text {. }\end{array}$ & May-01 & Q2 2004 \\
\hline Congo, Dem. Rep. of & $\begin{array}{l}\text { The I-PRSP was presented in June 2002. The full } \\
\text { PRSP is expected in the third quarter of } 2005 \text {. }\end{array}$ & $\begin{array}{l}\text { A PRGF arrangement was approved in June } 2002 \text {. The } 1 \text { st and } \\
\text { 2nd reviews of the PRGF supported program were completed } \\
\text { in March } 2003 \text { and July 2003, respectively. }\end{array}$ & Jul-03 & Q3 2006 \\
\hline Ethiopia & $\begin{array}{l}\text { The full PRSP was completed in August } 2002 \text {. The } \\
1 \text { st annual progress report expected in the fall of } \\
2003 \text {. }\end{array}$ & $\begin{array}{l}\text { The 3rd review under PRGF was completed in September } \\
\text { 2002. A Board discussion on the 4th review of the PRGF is } \\
\text { scheduled in August } 2003 \text {, following a delay in completing a } \\
\text { financial audit of the Commercial Bank of Ethiopia. }\end{array}$ & Nov-01 & Q1 2004 \\
\hline Gambia, The & $\begin{array}{l}\text { The full PRSP was finalized in April } 2002 \text { and } \\
\text { presented to the Boards in August } 2002 \text {. The 1st } \\
\text { annual progress report is expected in August } 2003 .\end{array}$ & $\begin{array}{l}\text { A PRGF was approved in July } 2002 \text {. The } 1 \text { st Review } \\
\text { expected in December } 2002 \text { has been delayed because of } \\
\text { fiscal and monetary policy slippages. Follow up mission in } \\
\text { July } 03 \text {. }\end{array}$ & Dec-00 & Q2 2004 \\
\hline Ghana & $\begin{array}{l}\text { The full PRSP was finalized in February } 2003 \text { and } \\
\text { presented to the Bank and Fund in May } 2003 \text {. The } \\
\text { 1st annual progress report could be completed by } \\
\text { March } 2004 \text {. }\end{array}$ & $\begin{array}{l}\text { The PRGF expired in November } 2002 \text { without a final review. } \\
\text { A new PRGF was approved in May } 2003 .\end{array}$ & Feb-02 & Q2 2004 \\
\hline Guinea 5/ & $\begin{array}{l}\text { The full PRSP was completed in January } 2002 \text { and } \\
\text { endorsed by the Boards in July } 2002 \text {. A PRSP } \\
\text { progress report is under preparation and is expected } \\
\text { by end } 2003 \text {. }\end{array}$ & $\begin{array}{l}\text { The PRGF went off track as of end- } 2002 \text { because of fiscal and } \\
\text { monetary imbalances. The staff is currently informally } \\
\text { monitoring economic performance, to set the ground for an } \\
\text { SMP in early 2004, and, provided a track record is established } \\
\text { under the SMP, to lead to a new PRGF in the second half of } \\
2004 \text {. }\end{array}$ & Dec- -00 & Q4 2004 \\
\hline Guinea-Bissau 5/ & $\begin{array}{l}\text { Progress toward the full PRSP has been slow. A } \\
\text { draft was A45available in April } 2003 \text { but detailed } \\
\text { costings and a review by donors are required before } \\
\text { finalization. }\end{array}$ & $\begin{array}{l}\text { The PRGF went off track in } 2001 \text { and the SMP that followed } \\
\text { incurred difficulties because of recurring fiscal policy } \\
\text { slippages. Completion of discussions on an SMP for } 2003 \text { has } \\
\text { been delayed because the government was dismissed in } \\
\text { November 2002. Elections are scheduled for October } 2003\end{array}$ & Dec-00 & Q2 2005 \\
\hline Guyana 5/ & $\begin{array}{l}\text { The full PRSP was published in November } 2001 \\
\text { and a macroeconomic addendum to it was } \\
\text { completed in April 2002. A progress report is } \\
\text { expected to be prepared by the second quarter of } \\
2004 \text {. }\end{array}$ & $\begin{array}{l}\text { A PRGF arrangement was approved in September 2002. The } \\
1 \text { st review under the PRGF arrangement has been delayed } \\
\text { because of fiscal and structural reform slippages. Prior } \\
\text { actions for the completion of the 1st review are expected to be } \\
\text { fulfilled by end-August } 2003 \text {. }\end{array}$ & Nov-00 & Q4 2003 \\
\hline
\end{tabular}

\section{CInternational Monetary Fund. Not for Redistribution}


Annex II (continued). HIPC Initiative: Progress in Implementation by country Status as of July 2003

\begin{tabular}{|c|c|c|c|c|}
\hline Country & $\begin{array}{c}\text { Progress in development and implementation of } \\
\text { PRSP }\end{array}$ & Performance under PRGF supported programs & $\begin{array}{c}\text { Actual/ } \\
\text { Expected DP } \\
\text { Date 1/ }\end{array}$ & $\begin{array}{c}\text { Actual/ } \\
\text { Expected CP } \\
\text { Date 1/ 2/ }\end{array}$ \\
\hline \multicolumn{5}{|c|}{ Countries between Decision and Completion Point } \\
\hline Honduras 5/ & $\begin{array}{l}\text { PRSP completed in August 2001. The 1st annual } \\
\text { progress report expected by the fourth quarter of } \\
2003 \text {. }\end{array}$ & $\begin{array}{l}\text { PRGF off track since December } 2001 \text { mainly due to fiscal } \\
\text { policy slippages. Discussions on a new PRGF could continue } \\
\text { in the fall of } 2003 \text {, depending on progress with the authorities' } \\
\text { strategy for achieving fiscal and financial sustainability. }\end{array}$ & Jul-00 & Q2 2004 \\
\hline Madagascar & $\begin{array}{l}\text { The full PRSP was delayed for about } 6 \text { months in } \\
2002 \text { due to political crisis. The full PRSP was } \\
\text { submitted in July } 2003 \text {. The } 1 \text { st annual review of the } \\
\text { PRSP could be completed by end-July } 2004 \text {. }\end{array}$ & $\begin{array}{l}\text { The 3rd review under the PRGF was completed in June } 2003 \text {. } \\
\text { An agreement was reached ad referendum to extend the } \\
\text { PRGF by } 9 \text { months to November } 2004 \text { to allow for the time } \\
\text { missed because of the election crisis in } 2002 \text {. }\end{array}$ & Dec-00 & Q3 2004 \\
\hline Malawi 5/ & $\begin{array}{l}\text { A full PRSP was finalized in April } 2002 \text { and the } \\
\text { first annual progress report is being prepared. }\end{array}$ & $\begin{array}{l}\text { PRGF reviews have been delayed since } 2001 \text { because of } \\
\text { fiscal policy slippages. The } 1 \text { st review is expected end- } \\
\text { September } 2003 \text {. }\end{array}$ & Dec-00 & Q3 2004 \\
\hline Nicaragua 5/ & $\begin{array}{l}\text { The full PRSP was presented to the Boards in } \\
\text { September } 2001 \text { and the } 1 \text { st annual PRSP Progress } \\
\text { was presented to the Boards in December } 2002 \text {. }\end{array}$ & $\begin{array}{l}\text { Earlier PRGF went off -track. A new PRGF was approved in } \\
\text { December 2002. The 1st and 2nd (quarterly) reviews were } \\
\text { completed on June 18, 2003. }\end{array}$ & Dec-00 & Q1 2004 \\
\hline Niger 5/ & $\begin{array}{l}\text { The full PRSP was submitted in January 2002. A 1st } \\
\text { PRSP Progress Report has been prepared and could } \\
\text { be presented to the Fund and Bank in October 2003. }\end{array}$ & $\begin{array}{l}\text { Despite some budget slippages earlier, overall performance } \\
\text { has been satisfactory. The 4th review of the PRGF } \\
\text { arrangement was completed in April } 2003 \text {. }\end{array}$ & Dec-00 & Q4 2003 \\
\hline Rwanda & $\begin{array}{l}\text { The full PRSP was finalized in June } 2002 \text {. The } 1 \text { st } \\
\text { annual progress report was issued in June } 2003 \text {. }\end{array}$ & $\begin{array}{l}\text { A new PRGF arrangement was approved in July, 2002. The } \\
\text { 1st review was completed in June } 2003 \text {. }\end{array}$ & Dec-00 & Q4 2003 \\
\hline São Tomé and Príncipe 5/ & $\begin{array}{l}\text { A full PRSP is expected to be submitted to the Bank } \\
\text { and Fund in the fourth quarter of } 2003\end{array}$ & $\begin{array}{l}\text { The PRGF arrangement went off track in } 2001 \text { because of } \\
\text { fiscal and structural reform slippages. Implementation of the } \\
\text { SMP in } 2002 \text { was broadly satisfactory and negotiations are } \\
\text { expected to be concluded soon for a new PRGF. }\end{array}$ & Dec-00 & Q4 2004 \\
\hline Senegal 3/5/ & $\begin{array}{l}\text { Full PRSP discussed by the Boards in December } \\
\text { 2002. The 1st annual PRSP progress report is } \\
\text { expected to be prepared in the fourth quarter of } \\
2003 \text {. }\end{array}$ & $\begin{array}{l}\text { A PRGF arrangement expired in April 2002, without the } \\
\text { conclusion of the last review, as fiscal imbalances reemerged } \\
\text { as a result of problems in public enterprises, and the } \\
\text { implementation of agreed structural reforms fell short of } \\
\text { target. A new PRGF arrangement was approved in April } \\
\text { 2003. }\end{array}$ & Jun-00 & Q4 2003 \\
\hline Sierra Leone & \begin{tabular}{|l|} 
The full PRSP, expected by mid 2003 , has been \\
delayed pending the demobilization of rebels, \\
resettlement of the populace and parliamentary and \\
presidential elections. The full PRSP is expected by \\
June 2004 .The 1 st PRSP progress report is expected \\
to be completed by July 2005 .
\end{tabular} & $\begin{array}{l}\text { A PRGF arrangement was approved in September 2001. The } \\
\text { 3rd review of the PRGF was successfully concluded in April } \\
2003 \text {. }\end{array}$ & Mar-02 & Q2 2005 \\
\hline Zambia & $\begin{array}{l}\text { PRSP was submitted in April } 2002 \text { and endorsed by } \\
\text { the Boards of the Fund and Bank in May 2002. The } \\
\text { 1st annual progress report is likely to be submitted } \\
\text { in September } 2003 \text {. }\end{array}$ & $\begin{array}{l}\text { The PRGF supported program was broadly on track but } \\
\text { expired before the completion of the final review because of } \\
\text { delays in the privatization of the National Commercial Bank. } \\
\text { The program has since gone off track due to large wage bill } \\
\text { overruns. }\end{array}$ & Dec-00 & Q2 2004 \\
\hline \multicolumn{5}{|c|}{ Countries still to be considered } \\
\hline Burundi & $\begin{array}{l}\text { The PRSP process was launched in July } 2000 . \\
\text { Progress in finalizing the final I-PRSP is expected } \\
\text { by July } 2003 \text {. }\end{array}$ & $\begin{array}{l}\text { Post-conflict assistance approved by Fund in October } 2002 \text {. } \\
\text { IDA provides support under Economic Rehabilitation Credit. } \\
\text { Program on track and a second request for post conflict } \\
\text { emergency assistance was been approved in May } 2003 \text {. }\end{array}$ & & \\
\hline Central African Republic 6/ & $\begin{array}{l}\text { The I-PRSP was presented in Jan 2001. The timing } \\
\text { of the full PRSP is uncertain. The delay is due to the } \\
\text { need to adress the weaknesses observed in the } \\
\text { preparation of the I-PRSP and to the issue of } \\
\text { recognition of the new authorities following the } \\
\text { coup d'etat in March } 2003 \text {. }\end{array}$ & $\begin{array}{l}\text { An SMP produced satisfactory results in } 2002 \text {. A Meeting was } \\
\text { held in Paris in March } 2003 \text { with the CAR authorities to } \\
\text { update the conclusions of the } 2003 \text { Article IV discussions, but } \\
\text { discussions were overtaken by a coup d'etat. At present, the } \\
\text { financing prospects for a new program are very difficult, } \\
\text { notably because of the arrears situation. }\end{array}$ & & \\
\hline Comoros & $\begin{array}{l}\text { The I-PRSP process was initiated in May } 2002 \text { but } \\
\text { lost some of its dynamics since the discontinuation } \\
\text { of the HIPC-process in } 2002 \text {. A draft I-PRSP has } \\
\text { been presented to the international community in } \\
\text { December 2002. However, the conflict between } \\
\text { union and islands has impeded that Comoros } \\
\text { advances in the PRSP-HIPC agenda. An I-PRSP } \\
\text { could be presented in early } 2004 \text { but would depend } \\
\text { on (i) developments in the country and the (ii) } \\
\text { design of the Bank's LICUS Strategy. }\end{array}$ & $\begin{array}{l}\text { The IMF suspended its SMP in July } 2002 \text {, when disputes } \\
\text { between the Union and island governments opened new era } \\
\text { of turbulence. Should conditions improve, a new SMP could } \\
\text { be put into place in } 2003 \text { with a new PRGF by spring } 2004 \text {. }\end{array}$ & & \\
\hline
\end{tabular}

\section{CInternational Monetary Fund. Not for Redistribution}


Annex II (concluded). HIPC Initiative: Progress in Implementation by country Status as of July 2003

\begin{tabular}{|c|c|c|c|c|}
\hline Country & $\begin{array}{c}\text { Progress in development and implementation of } \\
\text { PRSP }\end{array}$ & Performance under PRGF supported programs & $\begin{array}{c}\text { Actual/ } \\
\text { Expected DP } \\
\text { Date 1/ }\end{array}$ & $\begin{array}{c}\text { Actual/ } \\
\text { Expected CP } \\
\text { Date 1/2/ }\end{array}$ \\
\hline \multicolumn{5}{|c|}{ Countries still to be considered } \\
\hline Congo, Rep. of & $\begin{array}{l}\text { The I-PRSP is expected to be completed by October } \\
2003 .\end{array}$ & $\begin{array}{l}\text { Satisfactory results during the SMP period (January-June } \\
2003 \text { ). The timing of a possible PRGF arrangement and } \\
\text { preparation of a HIPC preliminary document will depend on } \\
\text { progress in the implementation through end-September } 2003 \\
\text { and normalization of relations with external creditors. }\end{array}$ & & \\
\hline Cote d'Ivoire & $\begin{array}{l}\text { A first draft of the full PRSP was prepared in } \\
\text { September 2002. The preparation of the full PRSP } \\
\text { and implementation of anti-poverty measures are } \\
\text { currently on hold because of civil strife. }\end{array}$ & $\begin{array}{l}\text { The PRGF arrangement, approved in March } 2002 \text { is off-track. } \\
\text { At issue is the incomplete structural reform program, together } \\
\text { with fiscal slippages and the accumulation of new external } \\
\text { arrears as the result of the socio-political crisis. Additionally, } \\
\text { the HIPC decision point was not reached in } 2002 \text { as initially } \\
\text { expected. }\end{array}$ & & \\
\hline Lao PDR & $\begin{array}{l}\text { The I-PRSP was discussed by the Boards in April } \\
\text { 2001. The final PRSP is expected by end-September } \\
\text { 2003. }\end{array}$ & $\begin{array}{l}\text { The Fund Board approved a PRGF arrangement in April 2001. } \\
\text { The 2nd review under the PRGF was completed in August } \\
2002 \text {. The 3rd review is delayed and is expected to take place } \\
\text { in the beginning of August } 2003 \text {. }\end{array}$ & & \\
\hline Liberia 6/ & & $\begin{array}{l}\text { Engagement remains on hold pending the lifting of sanctions } \\
\text { imposed by the UN in May 2001. Liberia has accumulated } \\
\text { arrears to the World Bank and to the Fund. }\end{array}$ & & \\
\hline Myanmar 6/ & $\begin{array}{l}\text { Without an active engagement with the World Bank } \\
\text { and Fund, Myanmar is not engaged in a process to } \\
\text { proceed with preparing in Interim PRSP. }\end{array}$ & $\begin{array}{l}\text { No Fund-supported program since } 1982 \text { or Bank lending since } \\
\text { 1987. Myanmar is in arrears to the Bank, as well as other } \\
\text { multilateral and bilateral agencies }\end{array}$ & & \\
\hline Somalia 6/ & Somalia is not engaged in a PRSP process. & $\begin{array}{l}\text { In partnership with UNDP and with the collaboration of other } \\
\text { development partners, the Bank has developed a } \\
\text { reengagement strategy. }\end{array}$ & & \\
\hline Sudan $6 /$ & $\begin{array}{l}\text { Government is currently preparing an I-PRSP in } \\
\text { consultation with other stakeholders and with } \\
\text { technical assistance from the Bank and the IMF }\end{array}$ & $\begin{array}{l}\text { The Bank has developed a reengagement strategy. SMP } \\
\text { continued to be in place during } 2002 \text { and } 2003 \text {. }\end{array}$ & & \\
\hline Togo 6/ & $\begin{array}{l}\text { The draft I-PRSP was issued in November } 2002 \text {. } \\
\text { The Boards would not discuss it due to the absence } \\
\text { of a stable macroeconomic framework and arrears } \\
\text { situation with the Bank. }\end{array}$ & $\begin{array}{l}\text { An SMP covering the period April-December } 2001 \text { was } \\
\text { established but performance was mixed. No PRGF is } \\
\text { scheduled in the near term. }\end{array}$ & & \\
\hline \multicolumn{5}{|c|}{ Potentially sustainable cases $7 /$} \\
\hline Angola & \begin{tabular}{|l} 
A new draft of the PRSP is expected to be \\
discussed with the donor community in mid-August \\
2003
\end{tabular} & $\begin{array}{l}\text { The Bank has a Transitional Support Strategy in place. The } \\
\text { Government formally requested an SMP, and the IMF Board } \\
\text { broadly supports the idea, with prior actions to be defined. }\end{array}$ & & \\
\hline Kenya & I-PRSP presented August 2000. & & & \\
\hline Vietnam & PRSP presented July 2002. & $\begin{array}{l}\text { Board report on eligibility to assistance under the HIPC } \\
\text { Initiative expected shortly. }\end{array}$ & & \\
\hline Yemen, Rep. of & $\begin{array}{l}\text { PRSP presented in June } 2002 \text { and discussed by the } \\
\text { Boards in August } 2002 .\end{array}$ & $\begin{array}{l}\text { The debt sustainability analysis done for Yemen in June 2000, } \\
\text { indicated that the country would have a sustainable debt } \\
\text { burden after application of traditional debt relief mechanisms. } \\
\text { The Paris Club provided a stock of debt operation on Naples } \\
\text { terms in July 2001. DSA indicated a sustainable debt burden } \\
\text { with application of traditional relief for } 2000 \text {. }\end{array}$ & & \\
\hline
\end{tabular}

Sources: IMF Country documents.

1/ Refers to the Enhanced HIPC Initiative.

2/ Based on staffs' judgment of progress towards the decision/completion point.

3/ Countries that are considered retroactive - not subject to the requirement to have a PRSP under implementation for at least one year under the enhanced framework.

4/ Completion point for Mali was approved by the World Bank and IMF's Executive Boards on March 6, 2003.

5/ Countries reported in the Fall 2002 Progress Report as having encountered difficulties in the implementation of their macroeconomic programs.

6/ Countries in non-accrual status with World Bank disbursements suspended.

7/These countries are expected to achieve debt sustainability after receiving debt relief provided under traditional mechanisms.

\section{CInternational Monetary Fund. Not for Redistribution}




\section{Enhanced HIPC Initiative: Country Implementation Status Notes}

\section{Implementation Status OF HIPCs In The INTERIM PeRiod \\ (AS OF THE END OF JULY 2003)}

\section{Cameroon}

PRSP Status: A full PRSP was presented to the donor community and civil society between December 2002 and March 2003 and endorsed by the World Bank and the Fund Boards at the end of July 2003. The authorities intend to produce a progress report on PRSP implementation by mid 2004. The document, built on a large consultative and participatory process, provides an adequate framework for guiding the implementation of a credible poverty reduction strategy. The final PRSP is based on several strong elements including: (i) the breadth and depth of poverty analysis; (ii) an approach for projecting the macroeconomic framework and costing the sectoral strategies, combining the "requirement approach" (the budget cost of reaching the sectoral and MDG targets) and the "availability approach"; (iii) clearly quantified targets that use the MDGs as benchmarks, with explicit timetables for achievement; (iv) a comprehensive development framework for sustainable growth and poverty reduction based on in-depth analysis on the source of growth; and (v) careful identification of the main priorities of the regional integration agenda.

Policy Performance: The third review of the 2000-2003 PRGF-supported program was completed in September 2002. The fourth review under the PRGF arrangement has been delayed due to difficulties in reconciling fiscal data and weak fiscal performance in early 2003. All quantitative performance criteria for the end of September 2002 (the end of the second annual program) were observed, except for net bank credit to the central government, which was missed by 0.7 percent of GDP due to a higher than programmed repayment of public domestic debt. Only one out of the five structural benchmarks for the end of September 2002 (i.e., implementation of the action plan for value-added tax credit reimbursement) was met as scheduled. However, the four missed structural benchmarks were all observed by mid-November 2002. Fiscal performance, other economic developments, and policy implementation during the first semester of 2003 are scheduled to be assessed by a staff visit to Cameroon in late August/ early September 2003, which could pave the way for the conclusion of the fourth review of the PRGF-supported program, depending upon progress made by the authorities.

Social and Structural Completion Point Triggers: Completion point triggers (in addition to macroeconomic performance) are in the areas of forestry reform, transport, governance, health (including HIV/AIDS), and education. Significant progress has been made in structural reforms included under the World Bank-supported Structural Adjustment Credit III, the closing date of which has been extended to December 2003. Important progress has been made in particular in the area of the social sectors, the implementation of the port reform and the public procurement reform. Greater effort will be needed for (i) the satisfactory implementation of the forestry reform especially the functioning of the newly created ANAFOR(Agence Nationale d'Appui au Development Forestier) and the enforcement of sanctions against illegal logging; and (ii) the completion of the budget tracking and beneficiary assessment survey in the social sectors. The 
newly created inter-ministerial committee in charge of monitoring progress in this area is expected to continue to play a key role.

Decision and Completion Points: The decision point was reached in October 2000. Cameroon could reach the completion point during the second quarter of 2004.

Creditor Participation: Cameroon has received financing assurances of total HIPC debt relief from creditors holding more than 98 percent of its debt. For commercial debt, agreement was reached on May 24, 2002 on a debt buyback operation supported by the World Bank. The operation was approved by the Board on a non objection basis in June 2003. Paris Club creditors, the World Bank, the Fund, the AfDB, the European Commission, and the Islamic Development Bank (IsDB) are providing interim assistance. So far, only Saudi Arabia has not yet committed to provide full HIPC relief. Bilateral agreements have been signed with Kuwait and China.

\section{Chad}

PRSP Status: The PRSP was delayed because of the time needed to conduct the participatory consultations and to prepare the macroeconomic framework. The PRSP was submitted to the Fund and the World Bank on June 6, 2003, and is expected to be followed by a donor round table in Geneva in November 2003. The first annual PRSP implementation review could be completed by the end of June 2004 .

Policy Performance: A PRGF arrangement was approved in January 2000 and extended to January 2004 following the completion of the fifth review in July 2003. Performance under the program has been broadly satisfactory. All quantitative benchmarks and performance criteria for September and December 2002 have been observed, except for the continuous performance criteria on the nonaccumulation of external payment arrears and the benchmarks relating to spending in health and education. Performance regarding structural conditions was less satisfactory, with one performance criteria and two benchmarks that were missed. GDP growth was strong as a result of accelerated investment in the oil sector, but inflationary pressures have had a negative impact on external competitiveness.

Social and Structural Completion Point Triggers: Progress on meeting conditions in the areas of governance, health (including HIV/AIDS), education, and rural infrastructure has been uneven, with continuous deterioration of some indicators in the health sector. Overall, most indicators in the social sectors and in rural development remain far from the target. This could delay the completion point. Corrective actions are being planned within the framework of the preparation of the 2004 program budgets.

Decision and Completion Points: Chad reached the decision point in May 2001. It is expected that the completion point could be reached by the end of June 2004.

Creditor Participation: Chad has received assurances of debt relief from creditors accounting for 93 percent of its debt at the decision point. Bilateral creditors including Cameroon; China; Côte d'Ivoire; Israel; Kuwait; Saudi Arabia; Senegal; Taiwan, Province of China; and Togo have not yet signed agreements to provide HIPC relief but presumably will do so after Chad reaches 
the completion point. Chad continues to receive HIPC interim assistance from the Bank, the Fund, the AfDB, the European Commission, the IsDB, the OPEC Fund, and Paris Club creditors. The Arab Bank for Economic Development in Africa (BADEA) granted interim assistance in the form of concessional rescheduling of arrears after the decision point.

\section{Democratic Republic of Congo}

PRSP Status: The I-PRSP was completed in June 2002, and completion of a full PRSP is expected in the third quarter of 2005. A JSA (Joint Staff Assessment) on the progress made in completing the PRSP was approved by the Boards of the Fund and the World Bank in July 2003. Social sector spending is targeted to increase from 7 percent of primary expenditure $(0.5$ percent of GDP) in 2002 to about 16 percent in 2003 (about 2 percent of GDP) to remedy the poor quality of and access to social services. The first annual review of PRSP implementation could be completed in the third quarter of 2006.

Policy Performance: A PRGF-supported program was approved in June 2002. For the first time in thirteen years, real GDP growth was positive ( 3 percent) in 2002, and this trend is projected to continue in 2003. The first review under the PRGF arrangement was concluded in March 2003, following broadly satisfactory performance in the economic reform program, under which public finances have been significantly strengthened, the cycle of hyperinflation and currency depreciation has been broken, major economic distortions are being removed, and significant improvements have been made in the judiciary and regulatory environment. The second review under the program was completed in July 2003.

Decision and Completion Points. The Democratic Republic of Congo reached the decision point in July 2003. It is expected that the completion point could be reached in the third quarter of 2006.

Creditor Participation: The Democratic Republic of Congo has received assurances of debt relief from creditors holding 94 percent of its debt at the decision point.

\section{Ethiopia}

PRSP Status: The full PRSP, completed in July 2002, builds on a broad-based participatory process and a sound poverty diagnosis. It focuses on promoting agriculture-led, rural -based growth, while improving the environment for exports and private sector growth. It recognizes the need to shift expenditures from military outlays toward social spending. The near-term goal is to reduce poverty from 44 percent in 1999/2000 to 40 percent by 2004/2005. The first annual progress report is expected in September 2003. The World Bank's strategy for supporting the PRSP is addressed in the Country Assistance Strategy for fiscal 2003-05, discussed by the Board in April 2003.

Policy Performance: A PRGF-supported program was approved in March 2001. A third review of the PRGF arrangement was completed in September 2002. Recent economic developments have been affected by a severe drought. Real GDP in 2002/2003 is estimated to have declined by 
3.8 percent reflecting a 12 percent drop in agricultural production. All quantitative performance criteria through December 2002, as well as the indicative targets for end-March 2003 were met. Some progress was made in meeting the structural benchmarks and performance criteria through January 2003. The introduction of the value-added tax, a structural benchmark and completion point trigger was carried out on time. However, two structural benchmarks (and completion point triggers) related to improvements in public expenditure management have been delayed primarily because of ongoing decentralization of fiscal powers to districts. The fourth review under the PRGF arrangement was postponed because of a delay in completing a financial audit of the Commercial Bank of Ethiopia (CBE). The audit has been finished and Board discussion of the fourth review is scheduled in August 2003.

Social and Structural Completion Point Triggers: Implementation of other completion point triggers on financial restructuring, health and HIV/AIDS are broadly on track although there are some delays in education and agriculture.

Decision and Completion Points: Ethiopia reached the decision point in November 2001. It is expected that the completion point could be reached in the first quarter of 2004.

Creditor Participation: Creditors holding 91 percent of Ethiopia's debt have agreed to provide HIPC debt relief. Paris Club creditors agreed in April 2002 to provide interim relief on Cologne terms. The Bank, the AfDB, the Fund, the European Commission, and the OPEC Fund are providing interim HIPC assistance.

\section{The Gambia}

PRSP Status: A full PRSP was completed in April 2002 and presented to the World Bank and Fund Boards in July 2002. The PRSP focuses on promotion of growth and employment; improved delivery of social services, stronger gender, HIV/AIDS, and environmental policies. Social spending increased from 5 percent in 2000 to about 6 percent of GDP in 2002, and it is projected to reach 6.3 percent of GDP by 2006. The first annual PRSP implementation report is expected to be ready in August 2003.

Policy Performance: A three-year PRGF arrangement was approved in July 2002, building on broadly encouraging economic performance under the previous arrangement. The first review of the PRGF, which was expected to be completed in December 2002, was delayed because of fiscal and monetary slippages. Performance criteria related to the government's primary balance were lower than targeted; they were accommodated by exceeding targets for domestic financing. Targets for international reserves and net domestic assets of the central bank were not met. Corrective fiscal measures were instituted from October, and most of the fiscal targets were achieved by the end of December 2002. The fiscal outlook for 2003 has deteriorated substantially. A financial safeguards assessment, required for the first review, was not concluded because of the failure of the central bank to provide audited financial accounts for 2001. One of the Bank's six active projects (Poverty Alleviation and Capacity Building) is currently rated as unsatisfactory because of poor execution arrangements. 
Social and Structural Completion Point Triggers: There is a significant risk that the completion point will be further delayed due to lack of progress in maintaining macroeconomic stability, as evidenced by current difficulties with the PRGF program. Satisfactory progress has been made in implementing conditions in health and education, but delays have been experienced in tracking the use of HIPC relief and promoting private sector development. Recent progress was made on the triggers for structural reforms (establishing the Multi-Sector Regulatory Agency and privatizing groundnut processing plants), but progress on these triggers continues to lag. Donors, including the World Bank, have indicated that continued efforts on structural measures are needed. In addition to the structural triggers, fulfillment of triggers related to PRSP implementation, the restructuring of the Central Statistics Department, and the allocation of recurrent budget for primary secondary health care are still pending.

Decision and Completion Points: The Gambia reached the decision point in December 2000. The enhanced HIPC completion point is unlikely to be reached by the third quarter of 2003, as earlier anticipated, given the interruptions in macroeconomic performance. A revised completion point target date has been set for the second quarter of 2004.

Creditor Participation: Creditors holding about 81 percent of Gambia's debt have agreed to provide HIPC debt relief. China; Kuwait; and Taiwan, Province of China, accounting for about 19 percent of HIPC relief, have not yet signed agreements to provide relief but could do so after the completion point. Paris Club creditors agreed in January 2003 to provide interim relief on Cologne terms. The Bank, the AfDB, the Fund, the European Commission, the IsDB, and the OPEC Fund are providing interim HIPC assistance. Among multilateral creditors, only the Economic Community of West African States (ECOWAS) has not yet committed to participate in the enhanced HIPC Initiative.

\section{Ghana}

PRSP Status: The full PRSP was published in February 2003 and subsequently endorsed by the World Bank and Fund Boards. Poverty-related spending is projected to increase to 6 percent of GDP in 2003, from 5.6 percent of GDP in 2002. The first annual progress report is under preparation and could be completed by March 2004.

Policy Performance: Following mixed program implementation in 2002, policy performance has improved but remains tenuous. In support of the government's efforts, the Fund Board approved a new PRGF arrangement in May 2003 and the World Bank Board approved a Poverty Reduction Support Credit a month later. The February 2003 spike in inflation due to price liberalization has been contained, and underlying inflation since has been in line with program projections. Good progress is being made in rebuilding the Bank of Ghana's official reserve position - consolidating gains achieved in 2002 - as donor support has been forthcoming and because of a stronger than expected cocoa harvest. Moreover, the implementation in early 2003 of some key structural reforms - in particular implementation of an automatic adjustment formula for retail petroleum prices and an automatic tariff adjustment mechanism for electricity tariffs - will substantially contain the subsidy burden on the budget. However, implementation of other structural reforms, including the privatization of the Ghana Commercial Bank and the 
National Health Insurance Levy, is being protracted to gather the necessary political consensus to move forward.

Social and Structural Completion Point Triggers: Triggers have been met in the areas of education and local-government service bill. Progress has also been made toward meeting triggers in the use of budgetary savings, procurement reform, installation of a computer-based financial management system, and electricity and petroleum pricing. Corrective measures will need to be discussed for five pending conditions: (i) full staffing of internal audit functions, (ii) monthly publishing in the government gazette of reports on cash expenditures and commitments by ministry departments and agencies, (iii) development of a district composite budget, (iv) expanding rural water coverage to 46 percent, and (v) raising recurrent health expenditures at district and lower-level governments to 45 percent of the total health budget.

Decision and Completion Points: Ghana reached the decision point in February 2002. If policies remain on track and PRSP implementation is satisfactory, the completion point could be reached in the second quarter of 2004.

Creditor Participation: Creditors holding about 89 percent of Ghana's debt have agreed to provide HIPC debt relief. The Bank, the Fund, the AfDB, the European Commission, and Paris Club creditors are delivering interim relief. Other multilateral creditors will provide relief only at the completion point. Among non-Paris Club bilateral creditors, agreements have been signed with China, the Kuwait Fund for Arab Economic Development, and the Saudi Fund for Development. India announced that it would cancel debt owed by Ghana. The Republic of Korea indicated its willingness to provide relief, but no agreement is in place. The participation of commercial creditors remains an issue.

\section{Guinea}

PRSP Status: A full PRSP was completed and adopted by the Council of Ministers in January 2002 and endorsed by the Fund and the World Bank Boards in July 2002. Social and povertyreducing spending has increased with the use of interim assistance. The authorities organized regional consultations to update the full PRSP. Those consultations revealed that, while the strategy as laid out in the PRSP was appropriate, some regions faced unique poverty-related problems, stemming from location and resource endowments. The regional poverty reduction strategies, conceived as subsets of Guinea's PRSP, are expected to be finalized by September 2003. The regional consultative process was deemed satisfactory, and progress in implementation has been good. The first annual PRSP Progress Report is under preparation and is expected by the end of December 2003.

Policy Performance: A PRGF-supported program was approved in March 2002. A first review of the PRGF was concluded in July 2002 after the authorities took measures in the first quarter of 2002 to correct weaknesses in revenue mobilization (particularly non-mining revenues) and to improve budgetary management, including through a better allocation of resources to priority sectors. Since then performance has been less than satisfactory, largely due to budget overruns in non priority sectors and excessive bank financing. The program went off track in December 2002 
because of fiscal and monetary imbalances. Negotiations on a SMP began in January 2003. The SMP could not be finalized because expansionary fiscal and monetary policies continued in the first quarter of 2003, reducing the likelihood that targets for the year would be achieved. Discussions are envisaged on a six-month SMP that could start in January 2004. Provided a track record of policy performance is established under the SMP, a new PRGF arrangement could be put in place in the second half of 2004.

Social and Structural Completion Point Triggers: Despite some early delays, good progress has been made in reaching completion point triggers in the areas of governance, regulatory framework for microfinance institutions, health, and education.

Decision and Completion Points: The completion point could be reached in late 2004 provided that Guinea performs satisfactorily under a PRGF that could be in place as indicated above.

Creditor Participation: Guinea has received satisfactory assurances of debt relief from creditors holding 85 percent of its debt at the decision point. The World Bank, the Fund, the AfDB, the European Commission, and Paris Club creditors had been providing interim assistance since 2001. However, in light of the poor implementation of the PRGF-supported program, some of the interim assistance has expired. Assistance from the Paris Club expired April 30, 2003, and the Fund's tranche of interim assistance expired June 30, 2003. Among non-Paris Club creditors, Egypt, Kuwait, and Morocco have indicated a willingness to provide HIPC relief. The othersBulgaria, Iraq, Romania, Saudi Arabia, and Thailand - have not indicated a willingness to provide HIPC relief but could do so after the completion point.

\section{Guinea-Bissau}

PRSP Status: Reflecting the difficult political circumstances and severe technical weaknesses, progress toward a full PRSP has been slow. A draft of the PRSP became available in April 2003, based on broad-based consultations with the administration, civil society, and other stakeholders and incorporating the results of the 2002 Small Poverty Assessment Survey. Finalization is planned for later in 2003, after detailed costings of proposed policies are completed and discussions are held with donors. As a result of severe financial difficulties, social sector spending remains low, at about 3 percent of GDP for 2002.

Policy Performance: The PRGF-supported program went off track immediately after it came into force at the end of 2000. The authorities have not been able to correct the situation, despite several efforts, including two short-term macroeconomic programs in 2001 and 2002.

Completion of discussions on an extended Staff-Monitored Program for 2003, which began at the end of 2002, has been delayed by the dissolution of Parliament and the dismissal of the government in November 2002. Legislative elections are now scheduled for October 2003 but may be postponed again. Recurring fiscal policy slippages are associated with heavy defense spending, increases in the wage bill, and political interference in public financial management. Ad hoc expenditure policies and general weakening of government finances contributed to a substantial decline in economic activity, with real GDP estimated to have declined by 4.2 percent in 2002 . 
Of the four IDA-financed projects, two - the Basic Education Project and the Economic Rehabilitation and Recovery Credit - are currently rated unsatisfactory. Encouraging, albeit slow, developments have occurred in addressing structural and social issues, including demobilization, public procurement reform, privatization, private sector development, and HIV/AIDS. In order to keep its reform agenda on track, the government has requested a restructuring of the IDA portfolio, with amendments to the Development Credit Agreements of the Basic Education and Private Sector Rehabilitation Projects. The restructuring package is currently being reviewed by Bank management. Two floating tranches remain to be disbursed under the Economic Rehabilitation and Recovery Credit, one with conditionality related to the government's demobilization program and the other with conditionality related to the government's domestic arrears settlement program. All specific conditions for release of both tranches have been met, but the tranches have not been released because of the unsatisfactory macroeconomic situation.

Social and Structural Completion Point Triggers: Progress on completion point triggers in education and governance has been slow; some progress is noted in health. The 2003 school year was launched after a four-month delay in January 2003 and has been disrupted by frequent work stoppages by teaching staff and administrative personnel. The Ministry of Education has not reported any data on enrollment or internal efficiency in primary education since 2001. Despite severe constraints on public financing, the Ministry is very much engaged in improving the performance of the health sector. Progress is noted in health services indicators, in particular increases in immunization coverage rates and decreases in childhood malaria cases. A national strategic HIV/AIDS plan was issued in May 2002 and adopted in June 2002. A national interministerial committee was created in December 2002. An HIV/AIDS project is under preparation. Governance remains extremely fragile. Public expenditure management remains a central focus of concern, as the current caretaker government has been unable to restore proper and transparent institutional arrangements for the budgetary process. In this context, the government is operating without an approved budget for 2003. Expenditure allocations are currently being made on the basis of the previous year's budget and resource availability rather than expenditure prioritization and performance. With declining tax revenues due to deteriorating economic activity and increased debt-service obligations, basic public services are operating at minimum capacity. Most public sector employees have not been paid for the last seven months, with the exception of the ministry of health employees, for whom salary arrears stand at two months.

Some progress has taken place in the demobilization program. The first phase of the program, involving the demobilization of about 4,000 military and paramilitary personnel, was completed in September 2002. The second phase, which covers reinsertion activities, is ongoing. The third phase, launched in March 2003, covers reintegration activities and is expected to be concluded in June 2004 with the demobilization, reinsertion, and reintegration of 11,300 ex-combatants.

Decision and Completion Points: Guinea-Bissau reached its decision point in December 2000. Completing the PRSP and building a track record before the completion point remains a challenge. As a consequence, the earliest possible date for reaching the completion point is estimated as mid-2005. 
Creditor Participation: Creditors holding more than 81 percent of Guinea-Bissau's debt at the decision point have agreed to provide HIPC relief. The Bank, the Fund, the European Commission, the AfDB, the International Fund for Agricultural Development (IFAD), and Paris Club creditors agreed to provide interim assistance. China and Cuba have written off their claims. Agreements to reschedule arrears have been concluded with a number of multilateral creditors, but because of the continuing political and economic problems, they have not been implemented for the most part. In view of continuing nonperformance under the PRGFsupported program, the Fund suspended its interim assistance at the beginning of 2002, and Paris Club creditors decided in January 2003 to stop applying the agreement on providing interim debt relief for 2002 and 2003.

\section{Guyana}

PRSP Status: A PRSP was published in November 2001. It was discussed, together with a macroeconomic addendum, by the Boards of the World Bank and the Fund in September 2002. A progress report is expected to be prepared over the next year. Poverty-reducing spendingspending on education, health, housing, water, and other poverty alleviation programs - has increased substantially since 1997, in both real and relative terms. It grew by an annual average of 5.9 percent in real terms between 1997 and 2002, faster than GDP growth (0.4 percent). As a share of GDP, poverty-reducing spending increased from 15 percent in 1997 to 20 percent in 2002. To support Guyana's poverty reduction strategy, two World Bank credits were approved in December 2002, a Poverty Reduction Strategy Credit and a Public Sector Technical Assistance Credit.

Policy Performance: The PRGF went off track in 2001, due to slippages in fiscal policy and stalled structural reforms. A new three-year PRGF-supported program was approved in September 2002 but the first review has been delayed because of slow implementation of agreed structural reform actions and difficulties in agreeing on measures to contain a significant deterioration in the fiscal deficit. Critical among the latter were limits to the public sector wage bill and an action plan to address weaknesses in the tax system. Policy implementation has progressed in the context of a deteriorated political and domestic security situation that adversely affected growth. All end-2002 quantitative performance criteria of the PRGF have recently been met, except for the Bank of Guyana's NDA and NFA limits owing to delays in programmed World Bank disbursements resulting from earlier policy slippages. Most of the structural performance criteria will have been met by the time of IMF Executive Board consideration of the first review (possibly at end-August 2003). Macroeconomic performance in 2003 remains consistent with recent understandings reached between the authorities and IMF staff.

Overall assessment of the World Bank's portfolio is satisfactory, but problems and delays have occurred. As a result, the Poverty Reduction Support Credit, which was approved in November 2002, has yet to become effective. The two key outstanding issues are a satisfactory macroeconomic framework and Parliament's approval of a satisfactory new procurement law (the law passed in June 2002 had serious deficiencies). In July 2003 Parliament enacted a new law, prepared in consultation with the World Bank, that represents a major improvement over the 
previous law and, for the most part, reflects the agreement reached by the government of Guyana and the Bank.

Social and Structural Completion Point Triggers: Triggers are in the areas of governance, civil service reform, education, privatization, and private sector development. The authorities are requesting that a pending completion-point trigger covering civil service downsizing be waived based on the sizeable employment reductions that have occurred in the public sector since the Decision Point. Another pending trigger (submission to Parliament of satisfactory investment legislation) is expected to be completed around mid-August 2003.

Decision and Completion Points: Guyana reached its decision point under the enhanced HIPC initiative in November 2000. The completion point could take place in the fourth quarter of 2003 if the remaining completion point triggers are met and the PRGF review is completed.

Creditor Participation: Creditors holding about 91 percent of Guyana's debt indicated at the decision point their intention to deliver debt relief. Fund interim relief lapsed at the end of 2001 but resumed in September 2002. The Bank, the IADB, and the European Commission are providing interim HIPC assistance. Argentina has begun negotiations with Guyana to provide relief, Brazil has already delivered HIPC relief, and India has announced its decision to write off all claims on Guyana. China, Kuwait, the People's Democratic Republic of Korea, the United Arab Emirates, Venezuela, and the Former SFR Yugoslavia have not signed agreements to provide HIPC relief but could do so after Guyana reaches the completion point.

\section{Honduras}

PRSP Status: A PRSP was completed in August 2001, and a first annual progress report is under preparation. Civil society was consulted on a draft progress report in April and May 2003. Public expenditures on poverty-reducing projects appear to have been below PRSP targets: spending of 3.2 percent of GDP in 2001 was below the 5.4 percent target, and spending of 2.5 percent of GDP in 2002 was below the target of 5.9 percent envisaged under the PRSP. Poverty-reducing spending is programmed to increase to 3.7 percent of GDP in 2003.

Policy Performance: A PRGF arrangement was approved in March 1999, and the third review under the program was completed in October 2001. The PRGF-supported program went off track at the end of 2001, due mainly to fiscal policy slippages associated with a continued increase in the government wage bill and weak tax collection. The program expired at the end of 2002. Since then the authorities have begun to develop a strategy to achieve fiscal sustainability and strengthen the financial sector, which they intend to develop with broad participation of society and which would form the basis of a new PRGF arrangement. Congress approved a tax reform to raise revenues by 2.5 percent of GDP in April 2003, and the authorities are preparing measures to reform the civil service, contain the deficits of public enterprises, and strengthen the financial system. On this basis, discussions on a new PRGF arrangement could continue in the fall of 2003. World Bank-funded operations (seven active projects) are currently rated as satisfactory. 
Social and Structural Completion Point Triggers: The authorities have been making good progress in implementing other reforms and in complying with completion point conditions, which are in the areas of governance, health, education, safety nets, social security, and financial sector reform. For example, in the governance area, an anti-corruption strategy was prepared and published in consultation with civil and donor community. Schools with community participation have been created, and the rate of student enrollment is more than satisfactory. The delivery of a package of health services has been delayed, but an action plan to meet the target has been agreed on.

Decision and Completion Points: Honduras reached the decision point in July 2000. If a new PRGF-supported program is put in place by the end of 2003, the completion point could be expected by the end of June 2004.

Creditor Participation: Creditors holding 93 percent of Honduras' debt have indicated their intention to deliver debt relief. The Paris Club and major multilateral creditors delivered interim relief in 2000 and 2001. However, interim relief from the World Bank and IDB ended in July 2002, because both institutions had reached the cumulative ceiling for interim relief. Interim relief from the Fund expired in October 2002, when the first tranche of assistance was fully exhausted. The agreement with Paris Club creditors expired in April 2002. Costa Rica, Mexico, and Venezuela have not yet agreed to provide HIPC relief to Honduras but could do so after the completion point.

\section{Madagascar}

PRSP Status: Madagascar submitted its full PRSP to the Fund and the World Bank in July 2003. The interim PRSP was presented to the Boards in December 2000, but the preparation of the full PRSP took significantly longer than had been expected due to the political crisis in the country, which paralyzed political and economic life during most of 2002. The final PRSP, which will be discussed by the Boards in the fall 2003, is markedly different from the pre-crisis PRSP, partly due to the social impact of the crisis necessitating emergency social policy actions. The government asked each sector ministry to formulate a mission statement and articulate how sectoral actions would contribute to poverty reduction. These new objectives form the backbone of Madagascar's PRSP. Budgetary allocations to priority social sectors have increased in recent years, with the budget allocation for education increasing from 3.0 percent of GDP in 1999 to 4.5 percent in 2003 and health spending rising from 1.2 percent of GDP in 1999 to 2.5 percent in 2003. The first annual review of the PRSP could be completed by the end of July 2004.

Policy Performance: A PRGF arrangement was approved on March 1, 2001, and the first review under the program was completed in December 2001. The political crisis of the first half of 2002 severely affected economic activity, and real GDP in 2002 dropped by 12.7 percent. The almost complete shutdown of the export-processing sector increased unemployment, and blockages in the transportation network impaired the marketing of agricultural output, causing a fall in real income. Since July 2002 the authorities have moved to ameliorate the situation by introducing various temporary tax measures to promote economic recovery and financial support measures designed to alleviate the impact of the crisis on the most vulnerable social groups. Policy 
implementation and performance, including performance on these measures, resulted in a satisfactory second PRGF review in December 2002. The third review of the PRGF-supported program was satisfactorily concluded in June 2003. In response to the crisis, the World Bank restructured its Second Structural Adjustment Credit in October 2002 based on the new policy reform priorities for public finance and anti-corruption. The adjustment program is now fully disbursed. The World Bank also approved an emergency credit (fully disbursed as of July 2003) to protect the most vulnerable and help relaunch the private sector. The Bank envisages a new Poverty Reduction Support Credit in fiscal year 2005.

Social and Structural Completion Point Triggers: Since the crisis ended in the fall of 2002, several HIPC supervision missions have taken place, jointly conducted by the Fund, the Bank, the European Commission, the AfDB, and UNDP. Progress on several sectoral reforms and actions in the health and transport sectors is satisfactory, as are some reforms pertaining to fiscal management (strengthening control organs, improving treasury operations, preparing budget execution laws). However, several reforms have only recently commenced, including those related to (1) establishing monitoring systems for the budgetary cycle in at least six ministries, including the ministries of basic education and health; (2) producing biannual reports on education and health sector activities at the central and decentralized level, including budgetary allocation, expenditure execution, and physical achievements; and (3) designing a transparent public information system on granting of licenses (beneficiary list, geographical zone, amount) in the mining, forestry, and fishing sectors. Although the government has hired 3,500 teachers, as stipulated in the education sector trigger, it has not provided information indicating whether these teachers were hired in (previously) disadvantaged schools. The government needs to include discussions of the use of HIPC funds in biannual PRSP discussions, as stipulated in the decision point document.

Decision and Completion Points: Madagascar reached the decision point in December 2000. The completion point could be reached by the end of July 2004.

Creditor Participation: At decision point, Madagascar has received satisfactory assurances of debt relief from creditors holding 91 percent its total debt. It continues to receive interim HIPC assistance from the World Bank, the Fund, the AfDB, the European Commission, and Paris Club creditors. So far, except China and Libya, none of Madagascar's non-Paris Club bilateral creditors has agreed to provide HIPC relief, but could do so after the completion point is reached.

\section{Malawi}

PRSP Status: The PRSP launched in April 2002 articulates a well-developed and sound strategy. There are detailed action plans to generate growth, improve social sector outcomes, protect the vulnerable, and improve governance. The resources made available from interim debt relief have been used to fund an expansion in pro-poor spending programs, including the health and education expenditures identified in the PRSP as primarily benefiting the poor. Spending on more broadly defined social programs is estimated at 8 percent of GDP in 2002. The first annual PRSP progress report is under preparation. 
Policy Performance: A PRGF-supported program was approved in December 2000. The program went off track before the completion of the first review, because of slippages in fiscal policy resulting from decisions to bail out parastatals, augment civil servants' wages, increase nonpriority spending, and reduce income taxes. Overall, program fiscal targets over the past two years were exceeded by 11 percent of GDP. The situation was exacerbated by one of the worst droughts in recent history, which adversely affected agricultural production and substantially slowed economic activity. During the first five months of 2003, significant progress was made in reducing inflation and implementing structural reforms. Fiscal targets for the end of March 2003 were met, and prospects for meeting end-June targets are encouraging. Substantial progress needs to be made on monetary targets, which were missed at the end of June 2003. Given recent indications of performance, the first review could be completed by the end of September 2003. The World Bank has 11 active credits in Malawi, one of which (the Regional Trade Facility) has an unsatisfactory rating.

Social and Structural Completion Point Triggers: Good progress has been made toward meeting the completion point triggers in governance and public expenditure management, education, health, land and credit reform, and development of social safety nets.

Decision and Completion Points: Malawi reached the decision point in December 2000. The completion point could be reached by the third quarter of 2004 if Malawi completes its first review of the PRGF and progress is made to satisfy the few outstanding triggers.

Creditor Participation: Malawi is receiving interim relief under the enhanced HIPC Initiative from the Bank, the AfDB, and the European Commission. Fund relief for 2002 and 2003 is pending conclusion of the first PRGF review, as well as the second and third phases of the Paris Club agreement signed in January 2001. With respect to non-Paris Club creditors, South Africa has written off its debt; no agreement has yet been signed with Taiwan, Province of China.

\section{Nicaragua}

PRSP Status: A full PRSP was presented to the Fund and World Bank Boards in September 2001, and the first annual PRSP Progress Report was completed in November 2002. Implementation of the PRSP has progressed since the decision point (December 2000), despite political difficulties. Relative to pre-Hurricane Mitch levels, poverty-reducing expenditures are projected to increase by about 4 percent of GDP by 2004-05. A mechanism for tracking the use of HIPC debt relief and poverty spending, designed in 2002 with Bank assistance, could become fully operational in early 2004.

Policy Performance: Nicaragua's 1998-2002 PRGF-supported program experienced policy slippages in early 2001, particularly in the fiscal and monetary areas. Discussions for a third annual arrangement could not be completed during the first part of 2001, and the authorities requested a SMP for July-December 2001. The SMP was not successful. The new government that took office in January 2002 reined in government spending through administrative means and a reduction in the budget. Based on this renewed commitment, in December 2002 the Fund Board approved a new three-year PRGF arrangement. Despite the difficult political situation, the authorities have persevered in implementing the program. Nicaragua's National Assembly 
approved the first stage of a comprehensive tax reform in August 2002 and the second stage in April 2003. To reduce financial sector vulnerabilities, the authorities have been implementing a recovery plan for assets of failed banks; the first and main auction took place in May. First and second reviews under the PRGF arrangement were concluded in June 2003. As of September 2002, all 15 projects in the World Bank's active portfolio were rated satisfactory.

Social and Structural Completion Point Triggers: Most measures in the remaining completion point triggers related to governance, social protection and human capital development, privatization and divestiture, and the pension fund system have been partially implemented or are being prepared. A draft civil service law satisfactory to IDA was presented to the National Assembly in 1999 but has not been approved yet. Progress has been made on social protection: a pilot social protection program was completed in 2002, and a draft conceptual framework for designing a social protection was presented in December 2002. The privatization of the telephone company, ENITEL, is underway. Forty percent of its shares and a management contract were awarded to a private entity in 2001, and another 11 percent of shares were divested by the end of 2002. The power-generating operations of the electricity company, ENEL, have been assigned to four successor companies, two of which have either been sold or are being operated by the private sector and two of which will be divested in 2003-04.

Decision and Completion Points: Nicaragua reached the decision point in December 2000 and could reach the completion point in early 2004.

Creditor Participation: At decision point, Nicaragua has received assurances of HIPC assistance from creditors holding 86 percent of its debt at the decision point. In principle, all multilateral with the exception of FOCEM (Fondo Centroamericano de Estabilizacion Monetaria, to which a small debt is owed, and Paris Club creditors agreed to participate, as did the following non-Paris Club creditors: Bulgaria, Costa Rica, the Czech Republic, Guatemala, Honduras, Hungary, India, Libya, Mexico, and the Slovak Republic. Iran is also considering to participate. Algeria; China; the People's Democratic Republic of Korea; Peru; Poland; Taiwan, Province of China; Venezuela; and the Former SFR Yugoslavia have not yet agreed to provide HIPC relief but could do so after the completion point is reached. Interim relief is being provided by the Bank, the Fund, the IADB, the CABEI, the OPEC Fund, and Paris Club creditors.

\section{Niger}

PRSP Status: A full PRSP was submitted to the Boards of the Fund and the World Bank in January 2002. It foresees an increase in social spending from 5 percent of GDP in 2001 to 7 percent through 2005 to improve poor social indicators. The first annual PRSP progress report, reflecting comments of the World Bank and Fund staffs, is to be finalized by mid-August 2003. Together with the joint staff assessment, it is expected to be presented to the Fund Board in the context of the fifth PRGF review and the World Bank Board in the third quarter of 2003, together with the HIPC completion point document.

Policy Performance: A PRGF arrangement was approved on December 14, 2000. A fourth review was completed in April 2003. The broadly satisfactory implementation of the program at the end of December 2002 has continued, with the observance of all quantitative performance 
criteria and indicative targets at the end of March 2003, except for the indicative target on revenue. The fifth review of the program is expected to be completed in October 2003.

Social and Structural Completion Point Triggers: Most of the completion point triggers in the areas of governance, education, and health have been met. Corrective measures will need to be discussed for five pending conditions: (i) evaluating the impact of public spending on the poor in the health sector, (ii) completing a report on impediments to primary school enrollment, (iii) limiting grade 6 repetition rate to 15 percent or less, (iv) adopting a plan to improve the availability of essential drugs in rural health centers, and (v) increasing national DPT3 immunization rates of 12- to 24-month-old children to 40 percent. An evaluation of the impact of public spending on the poor also remains to be done.

Decision and Completion Points: Niger could reach the completion point during the fourth quarter of 2003.

Creditor Participation: Niger has received financing assurances of HIPC assistance at the decision point for about 80 percent of its debt. Most non-Paris Club official bilateral creditors (Algeria; Iraq; Libya; Saudi Arabia; Taiwan, Province of China; and the United Arab Emirates) have not yet signed debt relief agreements but could do so after the completion point. China granted partial debt cancellation, and the Kuwait Fund recently provided a stock-of-debt rescheduling. Niger received adverse judgment in a U.S. court for claims by Taiwan, Province of China. ECOWAS has not agreed to participate in the HIPC Initiative. IFAD has committed to full debt relief at the completion point. The AfDB, the BADEA, the Bank, the Fund, the IsDB, the European Commission, the OPEC Fund, the West African Economic and Monetary Union (WAEMU), and Paris Club creditors have provided interim assistance.

\section{Rwanda}

PRSP Status: A PRSP was completed in June 2002 and discussed by the Boards of the World Bank and the Fund. The PRSP identifies six broad areas as priorities: (i) rural development and agricultural transformation, (ii) human development, (iii) economic infrastructure, (iv) good governance, (v) private sector development, and (vi) institutional capacity building. Spending in social sectors has been steadily increasing, and the trend is projected to continue. Such spending stood at 3.9 percent of GDP in 1999 and rose to 5.3 percent in 2001; it is projected to rise to 6.2 percent by 2003 and 6.4 percent by 2005. The first annual progress report was issued in June 2003. A draft has been submitted for consultations and will be presented to the Fund and World Bank Boards together with a joint staff assessment at the completion point.

Policy Performance: The 1998-2002 PRGF-supported program expired in April 2002 without completion of the final review. The first review of the new PRGF arrangement, approved in July 2002, was concluded in June 2003. Real GDP growth in 2002 is estimated at 9.4 percent, with strong performance in agriculture, manufacturing, construction, transportation, and communication. Performance was also satisfactory with respect to fiscal revenue collection, inflation, and the level of gross reserves. 
Social and Structural Completion Point Triggers: Progress in meeting the triggers in the areas of tracking HIPC expenditures, privatization, education, health, and gender has been satisfactory. All triggers related to HIPC expenditures, education, and gender have been met, and advances on the outstanding triggers have been significant.

Decision and Completion Points: Rwanda reached the decision point in December 2000. The completion point is expected to be reached in the fourth quarter of 2003.

Creditor Participation: Rwanda has received financing assurances of HIPC assistance from creditors holding 95 percent of its debt at the decision point. Interim assistance has been provided by the AfDB, the Bank, the Fund, the European Commission, and the Paris Club. BADEA and IFAD have agreed to provide HIPC relief at the completion point. The OPEC Fund has already disbursed its share of debt relief. Non-Paris Club creditors (China, Kuwait, Libya, Saudi Arabia, and the United Arab Emirates) have not signed agreements to provide HIPC debt relief, but they could do so after the completion point is reached.

\section{São Tomé and Príncipe}

PRSP Status: A full PRSP is expected to be ready in the third quarter of 2003 and could be submitted to the World Bank and Fund Boards in the fourth quarter of 2003. The first annual progress report is expected to be produced by October 2004. Five pillars would have been identified for the PRSP: (i) reforming public institutions, building capacity, and promoting good governance; (ii) fostering growth; (iii) creating opportunities to increase and diversify income for the poor; (iv) developing human resource and access to basic social services; and (v) adopting mechanisms to monitor, assess, and update the strategy.

Policy Performance: The 2000-2003 PRGF-supported program went off track in 2001 due to fiscal and structural reform slippages, compounded by oil sector governance concerns. Implementation of the subsequent Fund SMP during the first half of 2002 was disappointing, as key quantitative benchmarks for the end of June 2002 were not observed. Spending overruns were tied to trade union wage demands, higher energy and utility costs, and the legislative elections in March 2002. The SMP was extended through the end of December 2002 to enable reestablishment of a track record of policy implementation. Program implementation in the second half of 2002 and January-May 2003 was broadly satisfactory. A new PRGF arrangement was agreed to in early July, but political instability (a short-lived coup d'état followed by efforts to form a new democratic government) has placed the program on hold.

Social and Structural Completion Point Triggers: Significant progress has been made toward meeting the completion point triggers in the areas of education and health. Progress has been made on triggers on governance, except as regards the tribunal of arbitration in business and contract matters which is not yet operational. In education, schools construction is in progress. Immunization rates for children have increased.

Decision point and completion point: São Tomé and Príncipe reached the decision point in December 2000. The completion point, originally expected for the end of 2003, could be reached 
by end -2004, provided a PRGF program is in place and has been satisfactorily implemented and a satisfactory PRSP review is completed.

Creditor Participation: At decision point, São Tomé and Príncipe has received financing assurances of HIPC relief from creditors holding about 85 percent of its debt. Interim assistance is being provided by the Bank, the AfDB, and the European Commission. The Fund is not providing assistance, because it had no claims at the decision point. The OPEC Fund delivered its full share of debt relief in March 2003. Paris Club creditors have provided interim assistance, but due to track record interruptions, only the first phase of the May 2000 agreement was implemented. Non-Paris Club bilateral creditors (Algeria, Angola, Cape Verde, and China) have not signed agreements to provide HIPC relief but could do so after the completion point.

\section{Senegal}

PRSP Status: A full PRSP, discussed by the World Bank and Fund Boards in December 2002, is organized around the themes of wealth creation, human development, macroeconomic stability, and improved public expenditure management. Expenditures in education declined slightly, from 3.5 percent of GDP in 2000 to 3.4 percent in 2002. Expenditures in the health sector remained at about 1 percent over the period. A donors conference on the PRSP took place in Paris in early June 2003. The first annual PRSP progress report is expected to be prepared in the fourth quarter of 2003.

Policy Performance: The 1998-2002 PRGF-supported program expired in April 2002 without the conclusion of the last review. At issue were problems associated with the operations of the electricity and groundnut enterprises, which weakened public finances; and the implementation of reforms in the pension system. A new PRGF arrangement was put in place in April 2003. The World Bank has 21 active credits in Senegal, four of which (Quality Education for All, Urban Mobility, Transport II, and Information Systems Modernization) are currently rated unsatisfactory. The dialogue with country authorities has been continuing on the basis of the reform strategy outlined in the PRSP.

Social and Structural Completion Point Triggers: Progress in meeting the completion point triggers in privatization, education, health, and privatization has been slow. Technical problems have limited progress in the health sector. Implementation in the education sector has improved recently, and most of the triggers have now been met.

Decision and Completion Points: Senegal reached the decision point in June 2000. It could reach its completion point in the fourth quarter of 2003 if the PRGF is successfully implemented and adequate progress is made in meeting poverty triggers.

Creditor Participation: Senegal has received financing assurances of total HIPC debt relief from creditors holding about 79 percent of its debt . Non-Paris bilateral creditors (Algeria, China, Iraq, Kuwait, Oman, Saudi Arabia, and the United Arab Emirates) and two multilateral creditors (BCEAO, ECOWAS) have not yet agreed to provide debt relief. All remaining creditors have committed to provide debt relief. The Bank, the AfDB, the European Commission/European Investment Bank (EIB), the Banque Ouest Africaine Développement 
(BOAD), the Fund, and Paris Club creditors have provided interim assistance. The OPEC Fund delivered its full share of debt relief in November 2002. The Fund resumed the delivery of interim assistance in April 2003.

\section{Sierra Leone}

PRSP Status: An I-PRSP was completed in September 2001. The final PRSP was originally expected by mid-2003, but it was delayed pending the full disarmament and demobilization of Revolutionary United Front rebels; the resettlement and reintegration of internally displaced persons, refugees, and ex-combatants; and the holding of presidential and parliamentary elections. Administrative and financing difficulties also delayed the final PRSP. Despite these delays, significant progress has been achieved in establishing governance and institutional arrangements. Participatory data and information collection has commenced (an HIV/AIDS survey was conducted, for example). Some sector reviews have been completed (Transport Sector Strategy), others are being prepared (Rural Sector Review) or are planned for key sectors (education, infrastructure).The final PRSP is expected to completed by June 2004; the first PRSP annual review is expected to be completed by July 2005 .

Policy performance: Satisfactory progress has been made under the PRGF arrangement approved in September 2001. The third review was successfully completed in April 2003. The improved political and security situation has strengthened confidence and helped sustain the economic recovery. Structural reforms have been strengthened, and presidential and parliamentary elections were held peacefully in May 2002. A consultative group meeting took place in November 2002. Donors agreed to provide financial and technical assistance to consolidate the peace process. A Third Economic Rehabilitation and Recovery Credit was approved by the World Bank's Board in May 2003 to support the government's updated agenda for postconflict reconstruction and poverty reduction presented at the Consultative Group meeting.

Social and Structural Completion Point Triggers: Progress in implementing the five remaining triggers in health, education, governance and public expenditure management, and privatization/mining has been satisfactory.

Decision and Completion Points: Sierra Leone reached the decision point in February 2002. The completion point is expected by the end of 2004, once a full PRSP has been prepared and implemented satisfactorily for one year.

Creditor Participation: At decision point, Sierra Leone has received financing assurances of HIPC assistance from creditors holding 84 percent of its debt. One non-Paris Club official bilateral creditor, Morocco, has announced its intention to cancel all claims on Sierra Leone. Two non-Paris Club creditors (China and Saudi Arabia) agreed to deliver debt relief, but the amounts fall short of what is required under the HIPC Initiative. Another non-Paris Club creditor, Kuwait, has not signed an agreement to deliver debt relief but could do so after the completion point. Most multilateral creditors (the Bank, the Fund, the AfDB, the European Commission/EIB) and Paris Club creditors are providing interim assistance. IFAD and BADEA started providing 
assistance in the form of arrears clearance and will provide the rest of the assistance at the completion point.

\section{Zambia}

PRSP Status: A full PRSP was received in April 2002 and endorsed by the World Bank and Fund Boards in May 2002. It aims to promote growth and diversification in production and exports, to improve delivery of social services, and to foster appropriate policies for HIV/AIDS, gender, and the environment. Poverty-reducing spending was lower than programmed, due to initial difficulties in establishing an accounting framework and lack of implementation capacity. Priority poverty-reducing programs amounted to 1.1 percent of GDP in 2000, 2.1 percent in 2001, and about 2.2 percent of GDP in 2002. Preparations are underway for the progress report detailing the first year of implementation of the PRSP inclusive of an updated macro framework.

Policy Performance: The fifth review of the 1999-2003 PRGF-supported program was successfully completed in November 2002, notwithstanding capacity constraints and an adverse external environment, particularly in the copper sector. The government's financial policies in 2002 allowed for a reorientation of public expenditure toward the social sectors. Despite a wage bill overrun, the overall fiscal target for 2002 was on track. The privatization of the Zambia National Commercial Bank was delayed to allow for more public debate and to strengthen ownership of the reform program; while the strategy to privatize the Zambia Energy Supply Company was revised to one of commercialization. As a result, the previous arrangement expired without the final PRGF disbursement. Since then, a significant overrun of the wage bill has emerged, necessitating discussions on corrective actions.

Social and Structural Completion Point Triggers. Completion point triggers on PRSP implementation, HIV/AIDS, and health have been met. However, the following completion point triggers have not been met: (i) commercialization of the Zambia Energy Supply Company (ZESCO), (ii) implementation of an Integrated Financial Management Information System (IFMIS), and (iii) increasing discretionary budget share of education to 20.5 percent.

Decision and Completion Points: Zambia reached the decision point in December 2000. The completion point, initially envisaged for the end of 2003, is now expected by mid-2004.

Creditor Participation: At decision point, Zambia has received financing assurances of HIPC assistance from creditors holding about 97 percent of its total debt. The Bank, the Fund, the AfDB, the European Commission, and Paris Club creditors have provided interim relief. So far, Bulgaria, China, Iraq, Romania, and Saudi Arabia have not signed agreements to provide HIPC relief to Zambia but could do so after the completion point. India has announced its decision to write off all claims on Zambia. 


\section{Countries that Could Reach the Decision Point AFTer July 2003}

This section provides information on the status of 11 HIPC-eligible countries that could reach their decision points after July 2003. It does not include HIPCs whose debt burden is expected to be sustainable (Angola, Kenya, Vietnam, and Yemen). One country (Cote d'Ivoire) has had a preliminary document submitted to the Fund and World Bank Boards.

\section{Burundi}

PRSP Status: Nineteen political parties signed a peace agreement in August 2000 in Arusha, Tanzania, in an attempt to bring the civil conflict to an end. Agreement was reached in July 2001 on the installation of transitional institutions for a three-year period to lead to full democratization. The transitional arrangements culminated in the installation of an inclusive transition government in November 1, 2001, and the installation of the transition Parliament and Senate in January 2002. Political cooperation with the transition government continued with the successful handover of power from a Tutsi to a Hutu president in April 2003. Burundi launched its PRSP process in July 2000, and a draft I-PRSP was discussed by donors at a thematic roundtable meeting in April 2002. The civil conflict has continued, despite the best efforts of the international community to mediate.

Burundi authorities are incorporating comments provided by development partners, and the World Bank and Fund prepared a joint staff assessment of the final I-PRSP in the second quarter of 2003. The World Bank has been providing assistance in consultation and participatory diagnostic analysis. Burundi authorities recently requested further assistance in this area, within the context of preparing the full PRSP.

Policy Performance: In July 2001 agreement was reached on a SMP covering the period July 1 -December 31, 2001. In October 2002 the Fund Board approved a postconflict assistance facility for Burundi. This program, as well as Bank support under the Economic Rehabilitation Credit, is expected to be a catalyst for donor assistance. At the end of March targets under the program were observed and in May 2003 the Fund Board approved a second request for post conflict emergency assistance. Indications are that performance related to the end of June targets is also satisfactory. Given these developments, the Fund had initiated discussions on a mediumterm program that could be supported by a three-year PRGF arrangement. The Bank is currently supporting Burundi with the Economic Rehabilitation Credit and a number of other projects planned in the context of the Transitional Support Strategy. That strategy, approved by the World Bank Board on March 7, 2002, underpinned IDA assistance to Burundi during fiscal 2002-03. In addition to the Economic Rehabilitation Credit, it envisages exceptional Bank assistance to Burundi for HIV/AIDS, capacity building, health care, demobilization and reintegration, and social action.

Creditor Participation: Preliminary analysis indicates that Burundi has a heavy debt burden. It has managed to remain current in its debt-service obligations to the World Bank and the Fund but is in arrears to the AfDB. A Multilateral Donor Trust Fund has been set up to help Burundi clear 
its arrears and pay its debt to its multilateral creditors during the period leading to the enhanced HIPC Initiative. A number of donors have already contributed to the trust fund.

\section{Central African Republic}

PRSP Status: An I-PRSP was presented to the Bank and Fund Boards in January 2001. It emphasized the importance of rapid and broad-based economic growth, accompanied by a stable macroeconomic framework as prerequisites for poverty reduction. However, the I-PRSP did not set poverty reduction goals along the lines of Millennium Development Goals and did not discuss a macroeconomic framework beyond 2001. The JSA of the I-PRSP stressed that the PRSP would need to address weaknesses in the preparation of the I-PRSP. In particular, the work leading to the preparation of the PRSP would need to improve the statistical database; strengthen the participatory process; better prioritize the objectives for poverty reduction; clearly define quantitative targets for poverty reduction in the context of a detailed costing and financing exercise; and design an effective system for monitoring progress in reducing poverty, including the tracking of poverty outlays. In view of the fact that the issue of recognition of the new authorities (following the coup d'état in March 2003) is yet to be resolved, the timing of the full PRSP is uncertain.

Policy Performance: In October 2001 the authorities agreed with Fund staff on a six-month SMP. The successful completion of the program in June 2002 led to an agreement with the Fund on a three-year program to be supported by a PRGF, but the authorities' request could not be presented to the Fund Board because of a coup attempt and an outbreak of civil conflict in October 2002. Discussions with the authorities to conclude the 2003 Article IV consultations were overtaken by the coup d'état in March 2003. Currently, the financing prospects are uncertain, with increasing arrears to multilateral creditors, notably the IDA and AfDB. The Central African Republic has been in non accrual status with the World Bank since June 2002. Following the coup in March 2003, the donor community essentially suspended development assistance to the CAR. The World Bank was preparing a Country Reengagement Note under the LICUS framework before the events of October 2002. In light of the change in government in March 2003, the Bank is continuing with planned analytical work and discussing with the IMF, the EU and other donors on the appropriate timing and modalities for re-engagement in CAR, which will be determined largely by progress in governance and national reconciliation issues. In light of the uncertainty regarding re-engagement, the timing of the HIPC decision point is uncertain.

\section{Comoros}

PRSP Status: The PRSP process was initiated in March 2002, when the country was in the process of overcoming its secessionist crisis. Since then the reconciliation process has regressed substantially. The bottleneck remains the sharing of resources and the competencies of elected institutions of the Union and the islands. The PRSP process has proved to be a useful tool to facilitate discussions between the conflicting parties. The PRSP process, however, has lost some of its dynamic since mid-2002. An I-PRSP was updated and discussed through participatory 
workshops in May 2003 and could be presented to the boards of the Bank and the Fund in early 2004.

Policy Performance: Disputes between Union and island governments over competencies and revenue sharing led to suspension of the Fund SMP in July 2002. Discussions are ongoing, but after a Fund mission in June 2003, there are few chances that a new SMP could be instituted in 2003. As a result, prospects for debt relief under the HIPC Initiative will be delayed, at least until the end of 2004.

\section{Congo, Republic of}

PRSP Status: With the assistance of the World Bank and other active donors in the country, including UNDP, France, and the European Union, the government of the Republic of Congo is improving the content and the participatory process of the I-PRSP, taking into account comments on an early draft circulated to development partners in 2002. The I-PRSP is expected to be completed by October 2003.

Policy Performance: The Republic of Congo received Fund support under an emergency post conflict assistance program in November 2000. Performance under two successive SMP through 2002 was disappointing, as most fiscal and structural targets were missed. The public finances deteriorated, reflecting a combination of expenditure overruns and a drop in non-oil revenue collection. Significant improvements in policy implementation and structural reforms were registered in the fourth quarter of 2002, following the appointment of a new government in August 2002. Preliminary information on the execution of the third SMP (covering January-June 2003) indicates the continuation of this positive trend. As a result of this satisfactory performance under the current SMP, the Fund has initiated discussions on a medium-term program that could be supported by a three-year PRGF.

The timing of a possible three-year PRGF arrangement and preparation of a HIPC preliminary document will depend on progress in the implementation of reforms through end-September 2003, with a focus on improved fiscal performance, progress in transparency in the oil sector, and normalization of relations with external creditors.

The Republic of Congo cleared its arrears to the Bank on August 8, 2001, paving the way for the disbursement of already approved credits and new Bank lending. On July 31, 2001, the World Bank Board approved a Post Conflict Economic Rehabilitation Credit and an Emergency Demobilization, Disarmament, and Reintegration Credit. In addition, a recently approved Governance and Transparency Capacity Building Project is financing the external audit of the national oil company (SNPC). An audit of the entire oil sector will be undertaken at a subsequent date. 


\section{Côte d'Ivoire}

PRSP Status: The Fund and the World Bank Boards endorsed the IPRSP in March 2002. A first draft of the full PRSP was prepared in September 2002 and reviewe $\mathrm{d}$ by Bank and Fund staff. The intervening conflict, however, delayed completion of the PRSP an d implementation of anti-

poverty measures. Social sector spending by the central government fell slightly, from 4.6 percen t of GDP in 2000 to 4.4 percent of GDP in 2001. It had been projected to increase to 5 percent in 2003, but with the crisis extending into 2003, it is unlikely that this will be achieved. The PRSP process will be reactivated once the sociopolitical situation has fully stabilized.

Policy Performance: In March 2002, the Fund and the World Bank Boards discussed a prelimin ary HIPC document, and a three-

year PRGF arrangement was approved following the successful implementation of a SMP. Progr ess made toward fiscal consolidation during the first eight months was derailed by the outbreak o $\mathrm{f}$ the crisis. The primary surplus and overall deficit fell short of targets, reflecting expenditure ov erruns on defense spending and slippages in the wage bill, despite better than anticipated revenue performance. Budgetary and external payments arrears also increased. Since August 2002, exter nal payment arrears have increased from CFAF 91 billion to CFAF 427 billion at end-

May 2003. In addition, there were considerable delays in the implementation of structural measur es prior to the crisis and since then most of those measures have been put on hold. The incomplet e structural reform program, together with the accumulation of new external arrears, signals that $t$ he 2002-

04 program is off track. Given these developments, the HIPC decision point was not reached in 2 002 and cannot be envisaged before 2004 .

\section{Lao PDR}

PRSP Status: The Bank and Fund Boards considered the country's I-PRSP in April 2001. The first draft of the PRSP was delivered by the Lao authorities at the end of May 2003, and the final PRSP is expected by the end of September 2003.

Policy Performance: In April 2001, the Fund Board approved a new three-year PRGF arrangement with Lao PDR. The first review of the program was completed in February 2002, the second review in August 2002. The third review is currently delayed, pending measures by the authorities to prevent a recurrence of misreporting and measures to get the fiscal program back on track. The third review is expected to take place in August 2003.

The Bank Financial Management Adjustment Credit, a US\$17 million-equivalent IDA credit, builds on and supports the implementation of Lao PDR's current reform program. Approved in June 2002 and signed in mid-August, the credit was declared effective in December 2002. The first tranche was disbursed in January 2003. Release of the second tranche, originally scheduled for March 2003, has been extended to December 2003, pending measures by the authorities in the areas of public expenditure management, financial sector and state-owned enterprises. 
HIPC Status: Fund staff conducted a preliminary debt sustainability analysis in 2002. Agreement on the value and terms of debt has yet to be reached with one of Lao's bilateral creditors.

\section{Liberia}

Policy performance: Liberia continues to struggle with the loss of economic infrastructure and the human costs resulting from the ongoing civil war. In 2001 Liberia's relations with the international community deteriorated sharply after allegations of human rights abuses, support for an armed insurgency in Sierra Leone, and widespread government corruption. Liberian authorities had adopted a SMP with the intent of establishing a record of policy performance. Although some advances were made under the SMP, the policy performance record was not sufficient to proceed with a PRGF. Article IV consultations were held in December 2001 and most recently in December 2002. Liberia is in arrears to the Bank and the Fund.

In March 2003 the Fund's Board found that Liberia had not adequately strengthened its cooperati on with the Fund in terms of policy performance and payments and, therefore voted to suspend $\mathrm{Li}$ beria's voting and related rights.

HIPC Status: The stock of Liberian public sector debt amounted to about US\$3.1 billion (550 percent of GDP) at the end of 2002. At the end of 2002, Liberia was estimated to hold US\$2.8 billion in external debt; domestic debt was estimated at US\$0.32 billion as of September 30, 2002. External arrears at the end of 2002 amounted to US\$2.5 billion, of which 27 percent was to the Fund, 14 percent to the Bank, 7 percent to the AfDB, 26 percent to other multilateral creditors, and 26 percent to official bilateral creditors. Domestic arrears were estimated at more than US\$0.3 billion.

\section{Myanmar}

Policy performance: Myanmar has not had a Fund-supported program since 1981/82. Fund relations with Myanmar have been limited to annual Article IV consultations. The last consultation, concluded in October 2002, indicates that Myanmar's macroeconomic situation has deteriorated. The fiscal deficit spiked in 2000/01 and, despite declines in 2001/02, remains unsustainable. Low and declining revenue and spending allocations that favor defense have resulted in widespread poverty. Central bank financing of the deficit has produced a surge in inflation and a sharp depreciation in the parallel market exchange rate. The low import cover of reserves and continuing accumulation of arrears indicates a precarious external position. The deterioration in the institutional infrastructure, declines in various aspects of human capital, and governance problems continue to erode Myanmar's potential. The World Bank has approved no new lending since 1987 and does not have an active program in Myanmar.

HIPC Status: Myanmar is in arrears to the World Bank and to other multilateral and bilateral agencies. Poor debt statistics make assessment of the debt burden difficult. Highly tentative estimates indicate that Myanmar's debt ratios exceed the HIPC thresholds. Given Myanmar's poor relations with the international community and the lack of economic reforms, there is little 
prospect for moving beyond Fund surveillance at this stage. Without an active engagement with the Bank and Fund, Myanmar is not engaged in a process to proceed with preparing an I-PRSP or working to develop a track record of economic performance to receive HIPC relief.

\section{Somalia}

Under the auspices of the Intergovernmental Authority on Development (IGAD), a national reconciliation conference on Somalia opened in October 2002. The peace talks have reached the third and final phase, in which power-sharing arrangements are being discussed with a view of establishing an interim authority. During the second phase of the peace process, which examined key reconciliation issues, the World Bank provided technical expertise to the committee on economic recovery and trade. The Bank is an active member of the Somalia Aid Coordination Body (SACB), which provides a framework for UN agencies, international and Somali NGOs, and donors to develop a common approach for the allocation of international aid to Somalia.

Policy Performance: The World Bank has not had an active lending program in Somalia since 1991 because of an unstable security situation and lack of recognition of the current interim government. Significant arrears have accumulated on past debt-servicing obligations. A joint World Bank/UNDP Country Reengagement Note was elaborated for Somalia and approved by the Board in June 2003. Under the Country Reengagement Note, the following strategic entrypoints will be implemented: (i) support to macroeconomic data analysis and dialogue; (ii) creation of an enabling environment for the livestock and meat industry; (iii) coordinated action plan to address HIV/AIDS issues; and (iv) capacity-building for skills development and training centers. Through a Post Conflict Grant of US\$4.6 million, the Bank's will support the proposed Country Reengagement Note interventions. In support of this Note, a first Bank mission was sent to Somalia in June 2003. Somalia is in arrears to the Fund.

PRSP/PRGF and HIPC Status: Given the lack of active engagement with the World Bank and Fund, the security situation, and the lack of recognition of the current interim government, Somalia is not expected to proceed with preparing in I-PRSP. It is working to develop a track record of economic performance.

\section{Sudan}

PRSP Status: Peace talks between the government of Sudan and the Sudan People's Liberation Movement/Sudan People's Liberation Army are broadly on track, with significant support from international mediators. Discussions are continuing on political power and resource sharing, and on security issues. The two parties have expressed hope for a final agreement in 2003. The government is currently preparing an I-PRSP in collaboration with civil society.

Policy Performance: Sudan's economic performance under the 2002 SMP was satisfactory, with all quantitative benchmarks and almost all structural benchmarks implemented. The government agreed with Fund staff on a SMP for 2003. Fund Directors considered the 2003 SMP, like the 2002 SMP, to be of comparable strength to a Rights Accumulation Program (RAP). If the peace 
process advances and progress with reform continues, a RAP may be in place by the fall of 2003 . Some work has been completed in recent months to lay the groundwork for a possible arrears clearance for Sudan in the event that conditions improve sufficiently to allow for reengagement by the international community. ${ }^{1}$ Preliminary estimates suggest that the nominal amount of Sudan's debt will be about US\$21 billion at the end of 2003, of which about US\$18 billion will be in arrears. Around 70 percent of this debt is owed to non-Paris Club bilateral, commercial and multilateral creditors. The financing of these arrears may prove challenging for creditors, including the Fund. ${ }^{2}$ The additional resource requirements from the Fund for clearing arrears, delivering HIPC relief, and resuming lending on highly concessional terms are estimated at more than US\$1 billion. The Bank has developed a reengagement strategy, including options for the clearance of arrears, which stood at US\$256 million at the end of June 2003. The Reengagement Note was discussed with the Bank's Board in early July 2003.

\section{Togo}

PRSP Status: Presidential elections were held in early June 2003, leading to the reelection of the incumbent president. First reactions by donors to the elections indicate that an immediate resumption of financial assistance is unlikely. Preparation of an I-PRSP was initiated in 2002 and is expected to be finalized in the second half of 2003. However, as long as Togo has no stable macroeconomic framework and is on non-accrual status with the Bank, formal discussion of the I-PRSP by the World Bank and Fund Boards is not possible.

Policy Performance: Togo has not had a Fund-supported program since mid-1998. An enhanced Staff Monitored Program (SMP) was implemented during the period April-December 2001. However, performance was mixed and no agreement could be reached on an extension of this SMP. Subsequently, the authorities started implementation of a stabilization program, which was prepared in collaboration with Fund staff in the context of the April 2002 Article IV discussions. The program aims to demonstrate the authorities' commitment to stabilizing public finances, continuing the ongoing privatization of state-owned enterprises, and normalizing relations with external creditors. The Fund plans to assess performance of this program through an Article IV consultation planned for the second half of 2003. The World Bank released the final tranche of its last adjustment credit to Togo in May 1998. Accumulation of arrears with the Bank led to the suspension of disbursements on Bank investment operations between November 2000 and midAugust 2001. Following a further accumulation of arrears, Bank disbursements to Togo have been suspended since January 2002. As of June 30, 2003, Togo's arrears with the Bank stood at US\$26.6 million.

\footnotetext{
${ }^{1}$ The U.K. Department for International Development organized an informal workshop on Sudan's external debt problems in London in May 2003.

2 See IMF "Update on the Financing of PRGF and HIPC Operations and the Subsidization of Post-Conflict Emergency Assistance” March 21, 2003, SM/03/100, http://www.imf.org/external/np/tre/pledge/2003/023003/pdf.
} 


\section{Countries that Had Reached the Completion Point by the End of July 2003}

This section provides information on the status of the eight HIPC countries that reached their completion points before the end of July 2003.

\section{Benin}

External Debt Indicators after HIPC Debt Relief: Benin reached its completion point in March 2003. HIPC assistance amounted to US\$265 million. At the completion point, the net present value of the debt-to-exports ratio was projected at 161 percent in 2003, but is expected to fall below 150 percent in 2005 . At completion point, the net present value of debt-to-exports ratio deteriorated by about 30 percentage points relative to decision point projections (after accounting for a delay in the expected completion point). The decline was due primarily to lower exports associated with depressed cotton prices, lower discount rates at the end of 2001 relative to the base year, and higher than projected new borrowing. However, the debt-service ratio is expected to average around 7 percent for the 2002-10 period, in line with earlier projections.

PRSP Status: The authorities developed a full PRSP through a broad-based participatory process at the national and regional levels that was finalized in December 2002. In March 2003 the Fund and Bank Boards concluded that Benin's PRSP contains a credible poverty reduction strategy. The PRSP is accompanied by a detailed Medium-Term Expenditure Framework that builds on detailed program budgets for priority sectors (basic education, health, safe water, environment, rural development, and transportation) that link quantitative result targets, policies and actions, and expenditure (investment and recurrent costs). Under that framework, budget allocations for priority sectors will increase to 12.4 percent of GDP on average over 2003-05, up from 8.7 percent in 1996-99, and their share of total government expenditure will rise from 63.5 percent to 72.6 percent. An effort has also been made to better balance investment and recurrent costs in priority sectors. The fight against HIV has intensified, with a 2000-05 strategy to fight HIV/AIDS presented to the National Assembly. A roundtable is scheduled later in 2003 to elicit donor support.

Policy Performance: The three-year PRGF arrangement was approved by the Fund Board in July 2000. In July 2002 the Board approved the extension of the arrangement to March 2004. Benin's macroeconomic performance was strong and broadly in line with the program established for 2002. As a result, the fourth review of the PRGF-supported program was completed in March 2003. All performance criteria and structural benchmarks established for the end of September and the end of December 2002 were met. However, spending on health and education remained below quantitative benchmarks. All performance criteria and structural benchmarks established for end-September were met. There was progress in the implementation of structural reforms, particularly those regarding governance, the liberalization of the cotton sector, divestiture of public utilities, and the involvement of the private sector in the management of the port. However, civil service reform continued to stall, as the National Assembly did not vote on the legislation regarding the new compensation system for the civil service. 
Creditor Participation: Creditors holding 98.8 percent of Benin's debt at the completion point are providing HIPC relief. Interim assistance has been provided by the major multilateral creditors and the Paris Club. In April 2003 Paris Club creditors agreed to implement a stock-ofdebt reduction of US\$60 million in net present value terms, and all multilateral creditors have indicated their commitment to provide the debt relief required. Of the seven non-Paris Club bilateral creditors, China, Kuwait, and Libya have indicated their intention to provide HIPC relief. Debt owed to Argentina as well as commercial debt was settled through buyback operations.

\section{Bolivia}

External Debt Indicators after HIPC Debt Relief: Bolivia reached its completion point under the enhanced HIPC Initiative in May 2001. In net present value terms, HIPC assistance amounted to US\$448 million under the original framework and to US\$854 million under the enhanced framework. At the completion point, the net present value of debt-to-exports ratio after bilateral assistance beyond HIPC assistance was projected to remain well below the 150 percent throughout the projection period (2002-20). However, Bolivia's external debt indicators have deteriorated since its completion point under the Enhanced HIPC Initiative. According to the baseline projections under the Stand-By Arrangement, the net present value of debt-to-exports ratio would peak at 145 percent in 2004, falling to 137 percent by 2007 . These projections are subject to risks, including Brazil's desire to renegotiate its contract to buy Bolivia's natural gas exports and delays in reaching agreement over the project to export liquefied natural gas to California.

PRSP Status: The PRSP was completed in May 2001, and the first progress report is being prepared. Tracking of poverty-related expenditure requires improvement, especially at the localgovernment level. Social spending reached 12 percent of GDP in 2002 and is projected to increase to 13 percent in 2003.

Policy Performance: The PRGF arrangement expired in June 2001. A Stand By Arrangement was approved in April 2003 covering the period through April 2004. The core elements of the economic program are fiscal consolidation, strengthening of the banking and corporate sectors, and protecting and making more efficient social safety net spending. Real growth in Bolivia has been weak for the past four years, averaging 1.75 percent a year. Adverse shocks included the impact of coca eradication on incomes, the impact of low metal export prices on mining output and foreign direct investment, and contagion from the regional financial and economic developments. The economy's vulnerabilities have been heightened by fiscal imbalances and highly dollarized financial and corporate sectors.

Creditor Participation: Creditors holding about 95 percent of Bolivia's debt, including all multilateral creditors, have been delivering debt relief, and virtually all Paris Club creditors have provided relief beyond HIPC. Of the four non-Paris Club creditors, assurances of debt relief have not been provided by China and Taiwan, Province of China. Brazil committed to deliver its share of assistance when it participated to the April 2001 Paris Club Agreed Minute, but the bilateral agreement has not been signed yet. 


\section{Burkina Faso}

External Debt Indicators after HIPC Debt Relief: Burkina Faso reached its completion point in April 2002. In net present value terms, HIPC assistance amounted to US\$229 million under the original HIPC framework and to US\$195 million under the enhanced framework, of which US\$26 million additional assistance at completion point. At completion point, projections for the net present value of the debt-to-exports ratio were significantly higher than anticipated at the decision point. The increase was due to new borrowings in 2002-04 to finance public infrastructure and poverty alleviation measures; lower than projected export performance, resulting from a fall in export volumes (due to the impact of white fly); a decline in the international price of cotton and gold exports; and the adverse effects of tensions in Côte d'Ivoire on other categories of exports . Topping up assistance was provided at the completion point to mitigate the adverse effect on Burkina Faso's debt ratios resulting from exogenous shocks. At completion point, the net present value of debt-to-export ratio was projected at 190 percent, gradually decreasing to less than 150 percent by about 2016. Despite the hump of debt stock indicators, debt-service indicators are sustainable. At the completion point, the debt-service-toexports and debt-service-to-revenues ratios were projected to average 7 percent during 2002-21.

PRSP Status: The second progress report on the implementation of the PRSP was finalized in September 2002 and discussed by the Boards of the World Bank and the Fund in November 2002. Overall, the government has made good progress in fighting poverty, increasing social expenditures significantly in 2002. Total poverty-reducing social expenditure increased from 5.3 percent of GDP in 1999 to 7.5 percent of GDP in 2002. Regarding education, school enrollment improved. In the area of health, progress was made with regards to raising immunization coverage rates, increasing health center staffing and lowering the price of drugs and services.

Policy Performance: The Fund Board approved a new three-year program supported under the PRGF in June 2003. Implementation of the earlier PRGF-supported program (September 1999December 2002) was largely satisfactory. At the end of March and the end of June 2002, quantitative performance criteria, benchmarks, and indicators were met, except for the indicator on net budget financing and the government expenditure ceiling. On the basis of satisfactory implementation of the PRSP, the Bank Board approved a third consecutive poverty reduction support operation in July 2003. As regards HIPC-financed social spending, there was a marked acceleration in the commitment of resources in 2002 to make up for previous spending delays, with a further catching up of spending expected in 2003.

Creditor Participation: Creditors holding 88 percent of Burkina Faso's debt have agreed to provide enhanced HIPC relief. Financing assurances for topping up at the completion point have been obtained from the Bank, the AfDB, the Fund, the BOAD, the European Union, and Paris Club creditors, which together constitute 74 percent of total topping up assistance. Of the seven non-Paris Club creditors, Kuwait has committed to deliver its share of HIPC assistance. Saudi Arabia has not yet agreed to deliver assistance. The OPEC Fund, the IsDB, and BADEA have committed to deliver debt relief, but agreements are still pending. ECOWAS has indicated that it will not provide its share of assistance. 


\section{Mali}

External Debt Indicators after HIPC Debt Relief: Mali reached its completion point in March 2003. Assistance was US\$121 million at the end of 1998 in net present value terms under the original framework and US\$417.3 million in 1998 net present value terms under the enhanced framework. The net present value of debt-to-exports ratio at the completion point was lower than projected at the decision point, due to higher volumes of gold exports. It is projected to be 119 percent in 2003 after full delivery of HIPC assistance and bilateral debt relief beyond HIPC assistance and to remain below 150 percent throughout the projection period (2002-21). The debt-service-to-exports ratio is projected to remain below 10 percent.

PRSP Status: The full PRSP was considered by the Bank and Fund Boards in March 2003. Delays in the completion of the full PRSP were due mainly to the following three factors (i)the longer than anticipated participatory process; (ii) the time required for the new administration to review and endorse the PRSP during the summer of 2002; (iii) and the mismatch between the PRSP macroeconomic framework prepared in May 2002 and the updated framework underpinning the October 2002 budget. Budgetary allocations to priority sectors have increased steadily in line with the I-PRSP. Social expenditures increased from 4.4 percent of GDP in 2000 to 4.8 percent of GDP in 2002. They are projected to decline to 4.3 percent of GDP in 2003 (due mainly to slower than anticipated implementation of the health sector program) and to reach 4.9 percent of GDP in 2006.

Policy Performance: The PRGF-supported program, approved August 6, 1999, was extended by one year. It has been on track since Mali reached the enhanced HIPC decision point, in September 2000. The fifth review under the PRGF arrangement was completed in February 2003, and the sixth and final review was completed in July 2003. Economic growth was strong in 2002, as a doubling of cotton output boosted real GDP growth by 9.7 percent. The annual fiscal program was on track at the end of December 2002, and public resource management has been strengthened. Implementation of the reform of the cotton sector remains difficult. The crisis in Côte d'Ivoire has hit Mali's economy severely since September 2002. As a result and owing to lower rainfall, growth is projected to decline by 1 percent in 2003 and the fiscal position to weaken.

Creditor Participation: Mali has received financing assurances of HIPC assistance from creditors holding 93.5 percent of its total debt. Some non-Paris Club bilateral and commercial creditors and three multilateral creditors (BCEAO, ECOWAS, and the Foundation for Sustainable Development) have not yet agreed to provide debt relief to Mali. IDA, the Fund, the AfDB, the European Union, and Paris Club creditors have provided interim assistance.

\section{Mauritania}

External Debt Indicators after HIPC Debt Relief: Mauritania reached its completion point in June 2002. HIPC assistance amounted to US\$622 million in net present value terms. Debt indicators were slightly worse than projected at the decision point, due to higher new borrowing 
and lower exports than projected (as a result of external shocks to the price and demand for iron ore) and changes in discount and exchange rates. At the completion point, the net present value of debt-to-exports ratio was projected to be 157 percent in 2003, but it should decrease to less than 150 percent in 2006. The net present value of the debt-to-revenue ratio is currently at about 200 percent, well below the HIPC threshold of 250 percent. Debt-service ratios have improved significantly with HIPC assistance. The debt-service-to-exports ratio was 36.4 percent in 1999 before HIPC assistance and is projected at 11.3 percent in 2003. The debt-service-to-revenues ratio was 44 percent in 2002 before HIPC assistance and is expected to average about 14 percent of government revenue after HIPC assistance for the remainder of the decade. Mauritania's government-revenue-to-GDP ratio is high and is projected at 30 percent in 2003.

PRSP Status: The PRSP was finalized in early 2001 and endorsed by the Boards of the World Bank and the Fund; the first PRSP progress report was endorsed by both Boards in June 2002. A second PRSP progress report was presented to and approved by the Boards in July 2003. Social and poverty-reducing spending has increased with the use of domestic resources and interim assistance. However, more work needs to be done to improve expenditure tracking (with technical assistance from the Fund and the World Bank), and implementation capacity needs to be strengthened to allow full use of the resources freed up by HIPC relief. Nevertheless, even if progress remain to be made, the quality of reports on the execution of projects financed with HIPC assistance has improved, particularly regarding their likely poverty and social impact. Social indicators have improved. The two HIPC floating completion point triggers that were not met at the completion point have been met since: the child vaccination rate reached 82 percent in 2002 (exceeding the 70 percent target), and the secondary school enrollment rate increased to 24 percent in 2001, up from 20 percent in 2000. In contrast, the retention rate fell to 48 percent in 2002, down from 55 percent in 2000 and 51 percent in 2001.

Policy Performance: The sixth review under the PRGF program was completed in November 2002, based on Mauritania's strong economic performance. A new PRGF arrangement was approved by the Board of the Fund in July 2003. Economic growth has been robust, albeit lower than projected in 2002, due to drought and declines in exports of iron ore and fish. Inflation has been under control, and the external position has improved, despite the increase in the trade deficit that was mainly due to higher imports of oil machinery. Structural reforms have also intensified, creating an environment conducive to foreign and domestic investment. The country remains vulnerable to downside risks that could undermine its external position.

Creditor Participation: Mauritania has received satisfactory financing assurances of HIPC assistance from creditors holding more than 80 percent of its debt. In July 2002 Paris Club creditors agreed to deliver a stock-of-debt reduction of US $\$ 188$ million in net present value terms. The authorities have written to all non-Paris Club creditors to secure comparable treatment. Of the seven non-Paris Club creditors, Kuwait and Saudi Arabia have begun negotiations with Mauritania to deliver their share of HIPC assistance. Paris Club creditors have committed to deliver additional voluntary debt relief that would bring down the net present value of debt owed to them after HIPC assistance from US\$320 million to US\$6 million. 


\section{Mozambique}

External Debt Indicators after HIPC Debt Relief: Mozambique reached its completion point in September 2001. HIPC assistance amounted to US\$1,716 million under the original framework and to US\$306 million under the enhanced framework. At completion point, debt and debt-service ratios were better than projected at the decision point, reflecting in large part stronger than expected export performance. In the completion point document, the net present value of debt-to-exports ratio was projected to remain well below 150 percent throughout the projection period (2001-2020), falling from 94 percent in 2003 to 40 percent in 2020. The debtservice-to-exports ratio was projected to remain below 5 percent, while the debt-service-torevenues ratio was projected to decrease from 10.5 percent in 2003 to 5.4 percent in 2020 . The country has been largely spared from the effects of the global economic slowdown, and its export base is expected to benefit from the Mozal aluminum smelter and will benefit from further megaprojects as well as from its large agricultural potential.

PRSP Status: The PRSP, endorsed by the Boards of the World Bank and the Fund in September 2001, has been central in guiding the government's efforts to improve social welfare conditions and track poverty-reducing expenditures. HIPC-financed spending is being allocated to priority areas identified in the PRSP. Action Plans for Reducing Absolute Poverty (PARPA) priority sectors are in education, health (including HIV/AIDS), infrastructure, agriculture, and governance. Recent developments in social spending continue to be favorable. Such expenditures reached 9 percent of GDP in 2002 and are expected to remain at about that level through 2005. The first PRSP progress report was prepared in February 2003. A JSA was presented to the Boards in June 2003.

Policy Performance: A PRGF arrangement was approved by the Fund Board in June 1999. The fifth review under the PRGF arrangement was satisfactorily completed in June 2003. All quantitative and structural performance criteria and benchmarks were observed, with the exception of the performance criterion on domestic primary deficit. The macroeconomic outlook for Mozambique remains positive. Preliminary estimates indicate that GDP growth was 8 percent in 2002. For 2003-04 GDP growth is expected to reach 7 percent. Inflation for 2002 is estimated at 9 percent, well below the 2001 level of 21.9 percent.

Creditor Participation: Creditors holding about 88 percent of Mozambique's debt committed to provide debt relief. Of the sixteen non-Paris Club official bilateral creditors, Algeria, China, Kuwait, and South Africa have signed agreements to provide HIPC assistance. Agreements with India and Poland are expected shortly, but further negotiations are needed to finalize the agreements.

\section{Tanzania}

External Debt Indicators after HIPC Debt Relief: Tanzania reached its completion point in November 2001. HIPC assistance amounted to US\$2,026 million in net present value terms. Based on a debt sustainability analysis update conducted mid-2003, the net present value of debtto-exports ratio is projected to be lower than completion point projections, mainly because of an 
upward revision in exports. The debt ratio for 2003/2004 is projected at about 127 percent, down from 137 percent at the completion point. Due to a larger than expected depreciation of the shilling, government revenues are lower then projected at the completion point, with the net present value of debt-to-revenues projected at about 162 percent for 2003/2004, 13 percentage points higher than projected at the completion point. Potential risks for the debt outlook are the lack of diversification of the export base and the dependence of the economy on donor support. International prices for traditional exports, especially coffee and cashew nuts, are projected to remain low.

PRSP Status: The Poverty Reduction Strategy enjoys broad support and ownership. Tanzania presented its second annual PRSP progress report in May 2003. Expenditures on health and education have been rising since 1999/2000. New education, agriculture, and rural development strategies target high-priority areas of the PRSP.

Policy performance: The sixth and final review under the 2000-03 PRGF-supported program was completed in July 2003. The PRGF focuses on revenue mobilization, public financial management, and financial intermediation. Tanzania has made substantial progress in macroeconomic stabilization and has achieved rising real annual growth rates of about 5 percent since 2000. Progress under the PRGF has been satisfactory, with the exception of structural reforms (clearance of audited arrears and use of land as collateral for bank loans), which suffered from some delays. Poverty-reducing spending has increased in line with the Poverty Reduction Strategy, and a national debt strategy has been developed to ensure long-term debt sustainability. A new PRGF was approved by the Board in July 2003.

Creditor Participation: Tanzania has received financing assurances of HIPC assistance from creditors holding about 90 percent of its total debt. Multilateral and Paris Club creditors committed to deliver their share of HIPC assistance. In January 2002 Paris Club creditors agreed to deliver their assistance through a stock-of-debt reduction of US\$737 million in net present value terms; some Paris Club creditors indicated that they would provide additional bilateral debt relief. As of July 2003, only Japan and Brazil have yet to sign bilateral agreements. Of the twenty non-Paris Club creditors, China, India, Kuwait, and Libya indicated their intention to provide debt relief. Limited progress was made in securing debt relief from other non-Paris Club creditors.

\section{Uganda}

External Debt Indicators after HIPC Debt Relief: Uganda reached its completion point under the enhanced HIPC Initiative in May 2000. In net present value terms, HIPC assistance amounted to US\$347 million under the original framework and to US\$656 million under the enhanced framework. Uganda's external debt sustainability indicators have worsened since the completion point. The main factors underlying the deterioration of the debt sustainability indicators are the unanticipated 66 percent decline in the world price of coffee (Uganda's principal export) since 1999 and new borrowing between June 1999 and June 2001 that, though included in the decision point macroeconomic framework, was not included in the net present value of debt projections in the decision point document. As a consequence, the net present value of the debt-to-exports ratio 
rose from 150 percent at the completion point, assuming the full delivery of HIPC assistance, to 188 percent at the end of June 2002. This ratio is projected to peak at 193 percent in 2003, before gradually declining to 150 percent over the next ten years. The introduction of IDA grants to Uganda under IDA-13 arrangements is projected to help Uganda reach the 150 percent target. Despite the decline in exports, HIPC assistance has reduced the debt-service-to-exports ratio to sustainable levels, at about 8 percent in 2002/2003.

PRSP Status: The full PRSP was presented in March 2000. The first PRSP Progress Report, pre sented to the Boards of the World Bank and Fund in the spring of 2001, noted that the incidence of poverty fell from 56 percent in 1992 to 35 percent in 2000. The second PRSP Progress Report and the JSA were presented to the Board of the World Bank in July 2002. They were presented to the Fund Board in September 2002. The third PRSP Progress report is to be presented to the Boa rd of the Bank in September 2003 and the PRSP is scheduled to be revised later in 2003/04.

Policy Performance: A new PRGF arrangement for 2002/2003-2004/05 of SDR 13.5 million (7.5 percent of quota) was approved by the Fund's Board in September 2002, and the first review under the program was concluded in June 2003. Uganda's macroeconomic performance has been broadly satisfactory. A gradual fiscal consolidation to improve sustainability without jeopardizing poverty reduction programs is the centerpiece of the medium-term macroeconomic framework. Revenue collections have generally been on target, and expenditures limits are expected to have been respected in 2002/2003. Despite a sharp deterioration in the terms of trade in recent years, Uganda's external position has begun to recover, including solid growth in export earnings and rising international reserves.

Creditor Participation: Thirty-one of Uganda's forty four creditors have agreed to provide HIPC relief equivalent to about 96 percent of the total required. These include the governments of India, Libya, Pakistan and the Republic of Korea, which have recently pledged to provide debt relief on official debt. The East African Development Bank, the Eastern and Southern African Trade and Development Bank (PTA Bank), Shelter Afrique, Burundi, Iraq, Nigeria, the People's Democratic Republic of Korea, and the United Arab Emirates have not yet committed to provide debt relief. The courts have granted awards totaling US\$28.9 million, including interest charges and legal fees, to five creditors (Iraq and commercial creditors from Spain, the United Kingdom, and the Former SFR Yugoslavia). The Ugandan authorities paid out US\$14.5 million through 2002/03 to creditors from Spain and the Former SFR Yugoslavia but are appealing the awards to the remainder. 
Table 1. Enhanced HIPC Initiative: Committed Debt Relief and Outlook 1/ Status as of July 2003

(In millions of US dollars, in NPV terms in the year of the decision point)

\begin{tabular}{|c|c|c|c|c|c|c|c|}
\hline & \multicolumn{3}{|c|}{ Reduction in NPV Terms } & \multicolumn{3}{|c|}{ Nominal Debt Service Relief } & \multirow[b]{2}{*}{$\begin{array}{r}\text { Date of } \\
\text { Approval }\end{array}$} \\
\hline & $\begin{array}{c}\text { Original } \\
\text { HIPC } \\
\text { Initiative }\end{array}$ & $\begin{array}{c}\text { Enhanced } \\
\text { HIPC Initiative }\end{array}$ & Total & $\begin{array}{l}\text { Original } \\
\text { HIPC } \\
\text { Initiative }\end{array}$ & $\begin{array}{c}\text { Enhanced } \\
\text { HIPC Initiative }\end{array}$ & Total & \\
\hline \multicolumn{8}{|c|}{ Countries that have reached their Completion Points (8) } \\
\hline TOTAL & 2,862 & 5,470 & 8,333 & 5,730 & 8,965 & 14,695 & \\
\hline Benin & 0 & 265 & 265 & 0 & 460 & 460 & Mar-03 \\
\hline Bolivia & 448 & 854 & 1,302 & 760 & 1,300 & 2,060 & Jun-01 \\
\hline Burkina Faso 2/ & 229 & 324 & 553 & 400 & 530 & 930 & Apr-02 \\
\hline Mali & 121 & 417 & 539 & 220 & 675 & 895 & Mar-03 \\
\hline Mauritania & 0 & 622 & 622 & 0 & 1,100 & 1,100 & Jun-02 \\
\hline Mozambique & 1,717 & 306 & 2,023 & 3,700 & 600 & 4,300 & Sep-01 \\
\hline Tanzania & 0 & 2,026 & 2,026 & 0 & 3,000 & 3,000 & Nov-01 \\
\hline Uganda & 347 & 656 & 1,003 & 650 & 1,300 & 1,950 & May-00 \\
\hline \multicolumn{8}{|c|}{ Countries that have reached their Decision Points (19) } \\
\hline TOTAL & 256 & 22,496 & 22,752 & 440 & 35,999 & 36,439 & \\
\hline Cameroon & 0 & 1,260 & 1,260 & 0 & 2,000 & 2,000 & Oct- 00 \\
\hline Chad & 0 & 170 & 170 & 0 & 260 & 260 & May-01 \\
\hline Congo, Dem. Rep. of & 0 & 6,311 & 6,311 & 0 & 10,389 & 10,389 & Jul-03 \\
\hline Ethiopia & 0 & 1,275 & 1,275 & 0 & 1,930 & 1,930 & Nov-01 \\
\hline Gambia, The & 0 & 67 & 67 & 0 & 90 & 90 & Dec-00 \\
\hline Ghana & 0 & 2,186 & 2,186 & 0 & 3,700 & 3,700 & Feb-02 \\
\hline Guinea & 0 & 545 & 545 & 0 & 800 & 800 & Dec-00 \\
\hline Guinea-Bissau & 0 & 416 & 416 & 0 & 790 & 790 & Dec-00 \\
\hline Guyana & 256 & 329 & 585 & 440 & 590 & 1,030 & Nov-00 \\
\hline Honduras & 0 & 556 & 556 & 0 & 900 & 900 & Jul-00 \\
\hline Madagascar & 0 & 814 & 814 & 0 & 1,500 & 1,500 & Dec-00 \\
\hline Malawi & 0 & 643 & 643 & 0 & 1,000 & 1,000 & Dec-00 \\
\hline Nicaragua & 0 & 3,267 & 3,267 & 0 & 4,500 & 4,500 & Dec-00 \\
\hline Niger & 0 & 521 & 521 & 0 & 900 & 900 & Dec-00 \\
\hline Rwanda & 0 & 452 & 452 & 0 & 800 & 800 & Dec-00 \\
\hline São Tomé and Príncipe & 0 & 97 & 97 & 0 & 200 & 200 & Dec-00 \\
\hline Senegal & 0 & 488 & 488 & 0 & 850 & 850 & Jun-00 \\
\hline Sierra Leone & 0 & 600 & 600 & 0 & 950 & 950 & Mar-02 \\
\hline Zambia & 0 & 2,499 & 2,499 & 0 & 3,850 & 3,850 & Dec-00 \\
\hline \multicolumn{8}{|c|}{ Countries still to be considered (11) } \\
\hline Côte d'Ivoire 3/ & 345 & $\cdots$ & 345 & 800 & $\ldots$ & 800 & \\
\hline Burundi & $\ldots$ & $\cdots$ & $\cdots$ & $\ldots$ & $\ldots$ & $\cdots$ & \\
\hline Central African Republic & $\ldots$ & $\ldots$ & $\ldots$ & $\ldots$ & $\ldots$ & $\ldots$ & \\
\hline Comoros & $\ldots$ & $\ldots$ & $\ldots$ & $\ldots$ & $\ldots$ & $\ldots$ & \\
\hline Congo, Rep. of & $\ldots$ & $\ldots$ & $\ldots$ & $\ldots$ & $\ldots$ & $\ldots$ & \\
\hline Lao PDR & $\cdots$ & $\ldots$ & $\ldots$ & $\ldots$ & $\ldots$ & $\ldots$ & \\
\hline Liberia & $\cdots$ & $\cdots$ & $\ldots$ & $\cdots$ & $\cdots$ & $\cdots$ & \\
\hline Myanmar & $\ldots$ & $\ldots$ & $\ldots$ & $\ldots$ & $\ldots$ & $\ldots$ & \\
\hline Somalia & $\ldots$ & $\ldots$ & $\ldots$ & $\ldots$ & $\ldots$ & $\ldots$ & \\
\hline Sudan & $\ldots$ & $\ldots$ & $\ldots$ & $\ldots$ & $\ldots$ & $\ldots$ & \\
\hline Togo & $\cdots$ & $\cdots$ & $\cdots$ & $\cdots$ & $\cdots$ & $\cdots$ & \\
\hline \multicolumn{8}{|l|}{ Memorandum item: } \\
\hline Debt relief committed & 3,463 & 27,966 & 31,428 & 6,970 & 44,964 & 51,934 & \\
\hline
\end{tabular}

Sources: HIPC country documents; and World Bank and IMF staff estimates.

1/ Commited debt relief under the assumption of full participation of the creditors

2/ The assistance under the enhanced HIPC Initiative includes the topping up with the NPV calculated in the year of the completion point.

3/ Preliminary document issued. 
Table 2. Summary Debt Service for the 27 HIPCs that Have Reached the Decision Points (In million of US dollars, unless otherwise indicated)

\begin{tabular}{|c|c|c|c|c|c|c|c|c|}
\hline & 1998 & 1999 & 2000 & 2001 & 2002 & 2003 & 2004 & 2005 \\
\hline & \multicolumn{5}{|c|}{ Actual } & \multicolumn{3}{|c|}{ Projections } \\
\hline \multicolumn{9}{|l|}{ African Countries } \\
\hline Debt service paid $1 /$ & $2,632.6$ & $2,451.0$ & $2,404.0$ & $1,735.6$ & $1,693.3$ & & & \\
\hline Total debt service due after enhanced HIPC Initiative relief & & & & & & $1,769.1$ & $1,885.9$ & $1,957.0$ \\
\hline Ratio of debt service to exports (in percent) $2 /$ & 16.0 & 14.5 & 14.2 & 9.6 & 9.1 & 8.5 & 7.9 & 7.5 \\
\hline Ratio of debt service to government revenue (in percent) 2/ & 24.2 & 22.7 & 23.9 & 15.9 & 13.9 & 12.3 & 11.8 & 11.2 \\
\hline Ratio of debt service to GDP (in percent) 2/ & 3.4 & 3.1 & 3.3 & 2.3 & 2.1 & 1.9 & 1.9 & 1.8 \\
\hline \multicolumn{9}{|l|}{ Latin American Countries } \\
\hline Debt service paid $1 /$ & $1,063.4$ & 728.3 & 668.5 & 590.3 & 691.0 & & & \\
\hline Total debt service due after enhanced HIPC Initiative relief & & & & & & 678.3 & 625.0 & 666.6 \\
\hline Ratio of debt service to exports (in percent) $2 /$ & 19.9 & 14.4 & 11.9 & 10.7 & 12.5 & 11.6 & 9.9 & 9.9 \\
\hline Ratio of debt service to government revenue (in percent) 2/ & 28.3 & 19.3 & 17.5 & 15.7 & 18.4 & 16.7 & 14.1 & 14.3 \\
\hline Ratio of debt service to GDP (in percent) 2/ & 6.3 & 4.6 & 3.8 & 3.3 & 3.9 & 3.8 & 3.3 & 3.4 \\
\hline \multicolumn{9}{|l|}{ Total ( 27 countries) } \\
\hline Debt service paid $1 /$ & $3,696.0$ & $3,179.3$ & $3,072.5$ & $2,326.0$ & $2,384.3$ & & & \\
\hline Debt service due after enhanced HIPC Initiative relief & & & & & & $2,447.4$ & $2,510.9$ & $2,623.6$ \\
\hline \multicolumn{9}{|l|}{ Weighted average ( 27 countries) } \\
\hline Debt service/exports (in percent) & 16.9 & 14.5 & 13.6 & 9.8 & 9.9 & 9.1 & 8.3 & 8.0 \\
\hline Debt service/government revenue (in percent) & 25.2 & 21.8 & 22.2 & 15.8 & 14.9 & 13.3 & 12.3 & 11.8 \\
\hline Debt service/GDP (in percent) & 3.9 & 3.4 & 3.4 & 2.5 & 2.4 & 2.2 & 2.1 & 2.1 \\
\hline
\end{tabular}

Sources: HIPC country documents; and IMF staff estimates.

Note: Debt service figures for 1998 and 1999 reflect debt relief already provided to Bolivia, Guyana, Mozambique and Uganda under the original framework.

1/ The debt service figures for 2000 largely reflect pre-HIPC relief debt service because many countries did not reach their decision point until late in 2000

or later. Thus, the full impact of relief will not be felt until 2001 and thereafter.

$2 /$ Weighted averages. 
Table 3. Debt Service by Individual HIPCs that Have Reached the Decision Points — by Country

(In million of US dollars, unless otherwise indicated)

\begin{tabular}{|c|c|c|c|c|c|c|c|c|}
\hline & 1998 & 1999 & 2000 & 2001 & 2002 & 2003 & 2004 & 2005 \\
\hline & \multicolumn{5}{|c|}{ Actual } & \multicolumn{3}{|c|}{ Projections } \\
\hline \multicolumn{9}{|l|}{ Benin } \\
\hline Debt service due after enhanced HIPC Initiative relief $1 /$ & & & & & & 30.9 & 30.3 & 33.5 \\
\hline Debt service/exports (in percent) & 16.1 & 17.1 & 15.8 & 10.0 & 8.7 & 6.8 & 6.0 & 6.0 \\
\hline Debt service/government revenue (in percent) & 17.1 & 17.3 & 14.6 & 9.4 & 7.2 & 5.9 & 5.3 & 5.3 \\
\hline Debt service/GDP (in percent) & 2.8 & 2.8 & 2.4 & 1.5 & 1.2 & 1.0 & 0.9 & 0.9 \\
\hline \multicolumn{9}{|l|}{ Bolivia } \\
\hline Debt service paid & 390.0 & 249.4 & 268.3 & 248.3 & 253.4 & & & \\
\hline Debt service due after enhanced HIPC Initiative relief $1 / 2 /$ & & & & & & 279.3 & 294.2 & 327.3 \\
\hline Debt service/exports (in percent) & 28.6 & 19.0 & 18.3 & 16.3 & 16.3 & 16.7 & 16.1 & 16.7 \\
\hline Debt service/government revenue (in percent) & 19.2 & 12.7 & 13.7 & 13.4 & 14.4 & 15.8 & 15.2 & 16.2 \\
\hline Debt service/GDP (in percent) & 4.5 & 3.0 & 3.2 & 3.1 & 3.2 & 3.6 & 3.8 & 4.1 \\
\hline \multicolumn{9}{|l|}{ Burkina Faso } \\
\hline Debt service paid & 57.1 & 60.6 & 48.2 & 32.9 & 42.1 & & & \\
\hline Debt service/exports (in percent) & 17.7 & 23.9 & 23.4 & 14.7 & 17.8 & 8.6 & 8.3 & 8.0 \\
\hline Debt service/government revenue (in percent) & 15.7 & 15.8 & 15.6 & 10.6 & 11.3 & 5.3 & 4.7 & 4.3 \\
\hline Debt service/GDP (in percent) & 2.0 & 2.2 & 1.9 & 1.2 & 1.3 & 0.6 & 0.6 & 0.6 \\
\hline \multicolumn{9}{|l|}{ Cameroon $3 / 4 /$} \\
\hline Debt service paid & 401.0 & 401.0 & 437.2 & 260.9 & 232.7 & & & \\
\hline Debt service due after enhanced HIPC Initiative relief $1 / 12 /$ & & & & & & 288.5 & 295.5 & 288.8 \\
\hline Debt service/exports (in percent) & 18.0 & 14.6 & 16.0 & 9.6 & 8.9 & 9.8 & 10.5 & 10.4 \\
\hline Debt service/government revenue (in percent) & 28.0 & 24.1 & 26.3 & 14.8 & 12.0 & 12.3 & 12.0 & 11.2 \\
\hline Debt service/GDP (in percent) & 4.0 & 4.4 & 4.9 & 3.1 & 2.3 & 2.4 & 2.3 & 2.1 \\
\hline \multicolumn{9}{|l|}{ Chad 4/ } \\
\hline Debt service paid & 26.0 & 29.6 & 32.3 & 17.6 & 29.1 & & & \\
\hline Debt service due after enhanced HIPC Initiative relief $1 /$ & & & & & & 40.2 & 44.0 & 46.7 \\
\hline Debt service/exports (in percent) & 8.0 & 12.3 & 13.9 & 7.7 & 12.5 & 9.8 & 2.5 & 2.3 \\
\hline Debt service/government revenue (in percent) & 20.0 & 24.0 & 28.7 & 14.0 & 18.4 & 18.3 & 11.3 & 10.0 \\
\hline Debt service/GDP (in percent) & 2.2 & 1.9 & 2.3 & 1.1 & 1.5 & 1.5 & 1.0 & 1.0 \\
\hline Debt service due after enhanced HIPC Initiative relief 1/ & & & & & & 149.8 & 220.5 & 256.0 \\
\hline Debt service/exports (in percent) & 0.1 & 0.3 & 0.0 & 0.0 & 2.9 & 15.6 & 22.9 & 21.5 \\
\hline Debt service/government revenue (in percent) & 0.4 & 1.4 & 0.0 & 0.0 & 7.4 & 24.8 & 28.6 & 24.6 \\
\hline Debt service/GDP (in percent) & 0.0 & 0.1 & 0.0 & 0.0 & 0.6 & 2.7 & 3.7 & 3.9 \\
\hline \multicolumn{9}{|l|}{ Ethiopia 4/ 6/ } \\
\hline Debt service paid & 101.0 & 127.0 & 112.0 & 197.0 & 149.0 & & & \\
\hline Debt service due after enhanced HIPC Initiative relief $1 /$ & & & & & & 88.0 & 89.0 & 88.0 \\
\hline Debt service/exports (in percent) & 9.7 & 13.9 & 11.4 & 20.6 & 15.1 & 9.2 & 9.3 & 8.2 \\
\hline Debt service/government revenue (in percent) & 8.6 & 11.0 & 9.7 & 16.4 & 12.3 & 6.2 & 6.0 & 5.3 \\
\hline Debt service/GDP (in percent) & 1.5 & 2.0 & 1.7 & 3.0 & 2.5 & 1.3 & 1.2 & 1.1 \\
\hline \multicolumn{9}{|l|}{ Gambia, The 4/ } \\
\hline Debt service paid & 26.1 & 19.6 & 12.6 & 16.0 & 15.9 & & & \\
\hline Debt service due after enhanced HIPC Initiative relief $1 /$ & & & & & & 15.5 & 10.1 & 11.0 \\
\hline Debt service/exports (in percent) & 12.4 & 15.0 & 11.9 & 13.8 & 12.3 & 11.4 & 7.2 & 7.6 \\
\hline Debt service/government revenue (in percent) & 12.4 & 25.5 & 16.2 & 26.3 & 26.5 & 26.5 & 19.8 & 20.5 \\
\hline Debt service/GDP (in percent) & 6.2 & 4.5 & 3.0 & 4.3 & 4.5 & 4.9 & 3.6 & 3.8 \\
\hline \multicolumn{9}{|l|}{ Ghana 4/ 7/ } \\
\hline Debt service paid & 560.1 & 521.5 & 533.2 & 242.6 & 267.0 & & & \\
\hline Debt service due after enhanced HIPC Initiative relief $1 /$ & & & & & & 163.5 & 103.6 & 111.6 \\
\hline Debt service/exports (in percent) & 22.1 & 21.1 & 21.9 & 10.1 & 10.2 & 5.6 & 3.3 & 3.4 \\
\hline Debt service/government revenue (in percent) & 41.0 & 53.4 & 78.1 & 25.7 & 39.1 & 17.3 & 10.0 & 7.9 \\
\hline Debt service/GDP (in percent) & 7.5 & 6.7 & 10.7 & 4.6 & 4.3 & 2.3 & 1.3 & 1.4 \\
\hline \multicolumn{9}{|l|}{ Guinea $4 /$} \\
\hline Debt service paid & 128.2 & 131.5 & 143.8 & 75.3 & 85.2 & & & \\
\hline Debt service due after enhanced HIPC Initiative relief 1/ & & & & & & 89.2 & 78.9 & 68.5 \\
\hline Debt service/exports (in percent) & 15.5 & 17.6 & 19.6 & 9.2 & 10.9 & 10.4 & 8.6 & 7.1 \\
\hline Debt service/government revenue (in percent) & 33.5 & 35.3 & 45.5 & 22.2 & 22.0 & 23.3 & 19.5 & 15.4 \\
\hline Debt service/GDP (in percent) & 3.6 & 3.8 & 4.6 & 2.5 & 2.7 & 2.7 & 2.3 & 1.8 \\
\hline
\end{tabular}


Table 3 (continued). Debt Service by Individual HIPCs that Have Reached the Decision Points — by Country

(In million of US dollars, unless otherwise indicated)

\begin{tabular}{|c|c|c|c|c|c|c|c|c|}
\hline & 1998 & 1999 & 2000 & 2001 & 2002 & 2003 & 2004 & 2005 \\
\hline & \multicolumn{5}{|c|}{ Actual } & \multicolumn{3}{|c|}{ Projections } \\
\hline Guinea-Bissau 4/ & & & & & & & \\
\hline Debt service due after enhanced HIPC Initiative relief 1/ & & & & & & 5.1 & 5.6 & 3.6 \\
\hline Debt service/exports (in percent) & 23.5 & 10.7 & 19.1 & 0.7 & 7.7 & 7.7 & 7.7 & 4.4 \\
\hline Debt service/government revenue (in percent) & 62.6 & 15.5 & 31.6 & 1.2 & 12.0 & 12.0 & 13.6 & 7.5 \\
\hline Debt service/GDP (in percent) & 3.4 & 2.7 & 6.0 & 0.2 & 2.0 & 2.0 & 2.0 & 1.2 \\
\hline \multicolumn{9}{|l|}{ Guyana 4/8/ } \\
\hline Debt service paid & 130.8 & 70.0 & 78.0 & 52.8 & 59.0 & & & \\
\hline Debt service due after enhanced HIPC Initiative relief 1/ & & & & & & 46.5 & 37.9 & 36.2 \\
\hline Debt service/exports (in percent) & 19.0 & 10.4 & 11.2 & 8.0 & 8.8 & 6.8 & 5.4 & 5.2 \\
\hline Debt service/government revenue (in percent) & 65.5 & 35.0 & 34.4 & 24.0 & 25.4 & 18.8 & 14.0 & 12.9 \\
\hline Debt service/GDP (in percent) & 18.2 & 10.1 & 11.0 & 7.6 & 8.2 & 6.3 & 5.1 & 4.8 \\
\hline \multicolumn{9}{|l|}{ Honduras 9/ } \\
\hline Debt service paid & 311.2 & 239.8 & 137.5 & 135.9 & 220.6 & & & \\
\hline Debt service/exports (in percent) & 12.6 & 10.6 & 5.5 & 5.6 & 8.9 & 9.7 & 8.3 & 8.0 \\
\hline Debt service/government revenue (in percent) & 31.6 & 23.0 & 13.1 & 12.0 & 18.9 & 17.1 & 13.4 & 12.6 \\
\hline Debt service/GDP (in percent) & 5.9 & 4.4 & 2.3 & 2.1 & 3.3 & 3.4 & 2.7 & 2.5 \\
\hline \multicolumn{9}{|l|}{ Madagascar 4/ } \\
\hline Debt service paid & 166.1 & 106.3 & 64.9 & 44.9 & 50.5 & & & \\
\hline Debt service due after enhanced HIPC Initiative relief 1/ & & & & & & 53.6 & 72.5 & 72.7 \\
\hline Debt service/exports (in percent) & 20.6 & 11.7 & 5.5 & 3.4 & 6.6 & 5.2 & 6.4 & 5.9 \\
\hline Debt service/government revenue (in percent) & 41.7 & 25.0 & 14.3 & 9.7 & 15.4 & 10.4 & 12.6 & 11.2 \\
\hline Debt service/GDP (in percent) & 4.3 & 2.8 & 1.7 & 1.0 & 1.1 & 1.1 & 1.4 & 1.3 \\
\hline \multicolumn{9}{|l|}{ Malawi 4/ 10/ } \\
\hline Debt service paid & 90.1 & 64.6 & 102.7 & 74.1 & 47.2 & & & \\
\hline Debt service due after enhanced HIPC Initiative relief 1/ & & & & & & 66.9 & 38.9 & 50.6 \\
\hline Debt service/exports (in percent) & 15.6 & 13.0 & 23.0 & 15.4 & 9.9 & 13.6 & 7.5 & 9.3 \\
\hline Debt service/government revenue (in percent) & 21.9 & 20.5 & 34.5 & 23.8 & 14.1 & 18.9 & 9.6 & 11.7 \\
\hline Debt service/GDP (in percent) & 5.1 & 3.6 & 6.0 & 4.4 & 2.5 & 3.8 & 2.0 & 2.4 \\
\hline Debt service due after enhanced HIPC Initiative relief 1/ & & & & & & 59.5 & 63.0 & 66.1 \\
\hline Debt service/exports (in percent) & 11.5 & 12.3 & 12.2 & 6.2 & 6.1 & 5.0 & 4.9 & 4.8 \\
\hline Debt service/government revenue (in percent) & 17.4 & 19.6 & 20.8 & 12.7 & 11.9 & 8.4 & 8.1 & 7.7 \\
\hline Debt service/GDP (in percent) & 2.8 & 3.1 & 3.2 & 2.1 & 2.1 & 1.6 & 1.5 & 1.5 \\
\hline \multicolumn{9}{|l|}{ Mauritania } \\
\hline Debt service paid & 88.0 & 81.4 & 87.2 & 74.2 & 74.1 & & & \\
\hline Debt service due after enhanced HIPC Initiative relief 1/ & & & & & & 54.1 & 60.0 & 60.8 \\
\hline Debt service/exports (in percent) & 22.0 & 22.4 & 23.0 & 19.2 & 19.4 & 13.7 & 14.1 & 13.4 \\
\hline Debt service/government revenue (in percent) & 35.0 & 30.4 & 36.1 & 36.6 & 19.9 & 16.6 & 17.7 & 17.0 \\
\hline Debt service/GDP (in percent) & 10.0 & 8.5 & 9.1 & 7.5 & 7.5 & 4.9 & 5.0 & 4.7 \\
\hline \multicolumn{9}{|l|}{ Mozambique } \\
\hline Debt service paid & 104.0 & 60.2 & 18.0 & 27.1 & 42.0 & & & \\
\hline Debt service due after enhanced HIPC Initiative relief $1 /$ & & & & & & 47.1 & 50.9 & 57.3 \\
\hline Debt service/exports (in percent) & 41.0 & 9.4 & 2.5 & 2.7 & 3.5 & 4.0 & 3.0 & 3.0 \\
\hline Debt service/government revenue (in percent) & 23.2 & 12.3 & 4.1 & 6.7 & 8.3 & 8.0 & 7.6 & 7.5 \\
\hline Debt service/GDP (in percent) & 2.5 & 1.5 & 0.5 & 0.8 & 1.2 & 1.1 & 1.0 & 1.1 \\
\hline \multicolumn{9}{|l|}{ Nicaragua $4 / 11 /$} \\
\hline Debt service paid & 231.4 & 169.1 & 184.7 & 153.3 & 158.0 & & & \\
\hline Debt service due after enhanced HIPC Initiative relief 1/ & & & & & & 118.1 & 95.3 & 105.1 \\
\hline Debt service/exports (in percent) & 8.2 & 20.3 & 19.3 & 16.7 & 17.2 & 11.7 & 8.4 & 8.5 \\
\hline Debt service/government revenue (in percent) & 43.2 & 29.7 & 31.9 & 27.7 & 26.9 & 17.3 & 12.8 & 13.3 \\
\hline Debt service/GDP (in percent) & 10.5 & 12.5 & 7.6 & 6.0 & 6.1 & 4.4 & 3.4 & 3.5 \\
\hline \multicolumn{9}{|l|}{ Niger 4/ } \\
\hline Debt service paid & 17.0 & 18.9 & 22.4 & 34.1 & 53.0 & & & \\
\hline Debt service due after enhanced HIPC Initiative relief 1/ & & & & & & 26.0 & 28.8 & 29.0 \\
\hline Debt service/exports (in percent) & 5.0 & 5.9 & 7.9 & 12.5 & 17.5 & 7.3 & 7.9 & 7.6 \\
\hline Debt service/government revenue (in percent) & 9.0 & 10.6 & 14.3 & 19.1 & 21.4 & 9.4 & 9.7 & 9.0 \\
\hline Debt service/GDP (in percent) & 1.3 & 0.9 & 1.2 & 1.8 & 2.4 & 1.0 & 1.0 & 1.0 \\
\hline
\end{tabular}


Table 3 (concluded). Debt Service by Individual HIPCs that Have Reached the Decision Points — by Country (In million of US dollars, unless otherwise indicated)

\begin{tabular}{|c|c|c|c|c|c|c|c|c|}
\hline & 1998 & 1999 & 2000 & 2001 & 2002 & 2003 & 2004 & 2005 \\
\hline & \multicolumn{5}{|c|}{ Actual } & \multicolumn{3}{|c|}{ Projections } \\
\hline \multicolumn{9}{|l|}{ Rwanda 4/ } \\
\hline Debt service paid & 18.0 & 37.0 & 37.3 & 11.7 & 12.7 & & & \\
\hline Debt service due after enhanced HIPC Initiative relief 1 / & & & & & & 13.0 & 15.5 & 14.7 \\
\hline Debt service/exports (in percent) & 30.0 & 39.0 & 24.9 & 7.5 & 9.6 & 9.1 & 10.0 & 8.8 \\
\hline Debt service/government revenue (in percent) & 16.0 & 23.0 & 23.4 & 6.2 & 6.4 & 5.8 & 6.4 & 5.6 \\
\hline Debt service/GDP (in percent) & 2.0 & 2.4 & 2.1 & 0.7 & 0.7 & 0.8 & 0.9 & 0.8 \\
\hline \multicolumn{9}{|l|}{ São Tomé and Príncipe 4/ } \\
\hline Debt service paid & 6.6 & 2.0 & 4.0 & 1.9 & 2.0 & & & \\
\hline Debt service due after enhanced HIPC Initiative relief $1 /$ & & & & & & 3.2 & 2.1 & 1.1 \\
\hline Debt service/exports (in percent) & 55.0 & 11.8 & 25.5 & 11.1 & 10.1 & 13.7 & 8.2 & 4.1 \\
\hline Debt service/government revenue (in percent) & 84.1 & 21.4 & 42.4 & 17.9 & 15.9 & 23.3 & 10.7 & 4.5 \\
\hline Debt service/GDP (in percent) & 16.3 & 4.1 & 8.5 & 4.0 & 3.7 & 5.4 & 3.0 & 1.3 \\
\hline \multicolumn{9}{|l|}{ Senegal } \\
\hline Debt service paid & 207.0 & 178.0 & 164.7 & 137.7 & 164.6 & & & \\
\hline Debt service due after enhanced HIPC Initiative relief 1 / & & & & & & 146.4 & 141.4 & 138.7 \\
\hline Debt service/exports (in percent) & 15.0 & 12.0 & 12.6 & 9.8 & 10.7 & 8.8 & 7.9 & 7.3 \\
\hline Debt service/government revenue (in percent) & 26.0 & 22.0 & 20.7 & 17.0 & 16.4 & 13.3 & 11.8 & 10.7 \\
\hline Debt service/GDP (in percent) & 4.0 & 4.0 & 3.8 & 3.0 & 3.2 & 2.5 & 2.2 & 2.0 \\
\hline \multicolumn{9}{|l|}{ Sierra Leone 4/ } \\
\hline Debt service paid & 8.9 & 36.5 & 32.0 & 94.7 & 21.0 & & & \\
\hline Debt service due after enhanced HIPC Initiative relief $1 /$ & & & & & & 16.4 & 28.9 & 23.9 \\
\hline Debt service/exports (in percent) & 9.4 & 39.6 & 29.3 & 74.3 & 14.7 & 10.4 & 14.6 & 9.9 \\
\hline Debt service/government revenue (in percent) & 18.2 & 77.4 & 44.4 & 88.6 & 18.4 & 12.8 & 28.0 & 13.7 \\
\hline Debt service/GDP (in percent) & 1.3 & 5.5 & 5.1 & 12.2 & 2.7 & 3.0 & 4.0 & 2.2 \\
\hline \multicolumn{9}{|l|}{ Tanzania $6 / 11 /$} \\
\hline Debt service paid & 224.0 & 193.0 & 154.4 & 92.0 & 109.0 & & & \\
\hline Debt service due after enhanced HIPC Initiative relief 1 / & & & & & & 99.8 & 128.6 & 148.4 \\
\hline Debt service/exports (in percent) & 20.7 & 16.2 & 11.6 & 6.3 & 7.1 & 5.8 & 6.8 & 7.3 \\
\hline Debt service/government revenue (in percent) & 29.0 & 19.8 & 16.0 & 8.5 & 9.9 & 8.3 & 9.5 & 10.0 \\
\hline Debt service/GDP (in percent) & 2.8 & 2.2 & 1.7 & 1.0 & 1.2 & 1.1 & 1.3 & 1.4 \\
\hline \multicolumn{9}{|l|}{ Uganda 6/ } \\
\hline Debt service paid & 110.0 & 98.0 & 91.0 & 72.0 & 60.0 & & & \\
\hline Debt service due after enhanced HIPC Initiative relief 1 / & & & & & & 99.8 & 128.6 & 148.4 \\
\hline Debt service/exports (in percent) & 15.0 & 11.8 & 13.9 & 10.8 & 8.6 & 12.4 & 14.9 & 16.3 \\
\hline Debt service/government revenue (in percent) & 16.0 & 12.9 & 13.6 & 11.7 & 8.4 & 13.3 & 16.4 & 17.3 \\
\hline Debt service/GDP (in percent) & 1.7 & 1.7 & 1.5 & 1.3 & 1.0 & 1.6 & 2.1 & 2.3 \\
\hline \multicolumn{9}{|l|}{ Zambia 4/12/ } \\
\hline Debt service paid & 147.3 & 126.0 & 139.1 & 142.1 & 122.7 & & & \\
\hline Debt service due after enhanced HIPC Initiative relief 1 / & & & & & & 187.2 & 222.5 & 210.4 \\
\hline Debt service/exports (in percent) & 16.0 & 14.9 & 15.9 & 13.4 & 11.4 & 14.3 & 15.5 & 12.7 \\
\hline Debt service/government revenue (in percent) & 24.3 & 22.9 & 29.6 & 21.7 & 20.0 & 27.2 & 31.3 & 27.5 \\
\hline Debt service/GDP (in percent) & 4.5 & 4.0 & 4.3 & 3.9 & 3.3 & 4.7 & 5.3 & 4.7 \\
\hline Total debt service paid 4 / & 3696.0 & 3179.3 & 3072.5 & 2326.0 & 2384.3 & & & \\
\hline Total debt service due $\mathbf{1}$ / & & & & & & 2447.4 & 2510.9 & 2623.6 \\
\hline \multicolumn{9}{|l|}{ Ratio of debt service to exports (in percent) } \\
\hline Simple average & 18.1 & 15.9 & 15.2 & 12.3 & 10.3 & 9.7 & 9.1 & 8.4 \\
\hline Weighted average & 17.5 & 14.7 & 13.6 & 9.8 & 9.9 & 9.1 & 8.3 & 8.0 \\
\hline \multicolumn{9}{|l|}{ Ratio of debt service to government revenue (in percent) } \\
\hline Simple average & 29.1 & 24.0 & 25.0 & 18.4 & 15.9 & 14.7 & 13.5 & 11.9 \\
\hline Weighted average & 27.3 & 21.4 & 22.2 & 15.8 & 14.9 & 13.3 & 12.3 & 11.8 \\
\hline \multicolumn{9}{|l|}{ Ratio of debt service to GDP (in percent) } \\
\hline Simple average & 5.0 & 3.7 & 4.1 & 3.1 & 2.8 & 2.7 & 2.4 & 2.2 \\
\hline Weighted average & 4.1 & 3.4 & 3.4 & 2.5 & 2.4 & 2.2 & 2.1 & 2.1 \\
\hline
\end{tabular}

Note: Debt service figures for 1998 and 1999 reflect debt relief already provided to Bolivia, Guyana, Mozambique, and Uganda under the original framework.

1/ Debt service due after the full use of traditional debt relief mechanism and assistance under the enhanced HIPC initiative. For Bolivia, Mauritania, and Mozambique, these figures are also after additional bilateral assistance beyond HIPC. For Burkina Faso, topping-up of debt relief is taken into account.

Mozambique, these figures are also after additional bilateral assistance beyond HIPC. For Burkina Faso, topping-up of debt relief is taken
2/ Debt service is higher than anticipated at the completion point partly of because of higher new borrowing than previously projected.

$3 /$ In June 2003, the presentation has been changed from fiscal to calendar years. Debt service due in 2003 includes buyback of commercial debt from the London Club. Debt service payments for 2004 and 2005 have been revised upwards to reflect results from an updated DSA.

4/ The debt service figures for 2000 largely reflect pre-HIPC relief debt service because these countries did not reach their decision point until late in 2000 or later. Thus, the full impact of relief for did not take effect until 2001 and thereafter.

5/ The Democratic Republic of Congo reached its decision point in July 2003, and debt service numbers for the previous years reflect pre-HIPC debt service payments. The increase in debt service payments in 2003 and beyond is partly due to debt service payments following arrears clearance operations. 6/ On fiscal year basis, i.e. 2000 column shows FY 1999/2000.

6/ On fiscal year basis, i.e. 2000 column shows FY 1999/2000.
7/ Debt service payments in 2002 include arrear payments.

8/ Debt service in 2002 is higher than anticipated at the decision point because the completion point has been delayed.

9/ The increase in debt service in 2003 is due to Honduras receiving less debt relief than anticipated at the decision point. This shortfall is related to interruptions in the PRGF program and a delay in the completion point.

10/ The increase in debt service payments in 2003 reflects lower than expected interim relief because of program interruptions, a delay in the completion point and the projected early repayment of emergency assistance to the Fund.

11/ Debt service due in 2002/03 reflects a hypothetical assumption that arrears to non-Paris Club creditors (about US $\$ 2$ billion) would be regularized and serviced. It also reflects upfront payments associated with debt rescheduling agreements.

11/ Debt service reflects some payments to commercial creditors and payments on moratorium interest not reflected in the completion point document. 12/ The relatively high debt service payments in 2003-05 reflect Zambia's obligation to repay a large PRGF loan to the Fund. To lessen the debt service burden the Fund decided at the decision point, on an exceptional basis, that Fund assistance should amount to 75 percent of total Fund debt relief compared with the maximum of 60 percent otherwise applicable. It was also decided to accelerate delivery of Fund assistance, thereby lowering Zambia's debt service payments in 2001-03 considerably. With the bulk of Fund assistance disbursed by 2003, debt service payments will rise markedly in 2004 and 2005.

However, in 2006 debt service payments to the Fund will decline sharply. 
Table 4. Summary of Poverty-Reducing Expenditures by the 27 HIPCs that Have Reached the Decision Points 1/

\begin{tabular}{|c|c|c|c|c|c|c|c|}
\hline & 1999 & 2000 & 2001 & 2002 & 2003 & 2004 & 2005 \\
\hline & \multicolumn{3}{|c|}{ Actual } & Estimate & \multicolumn{3}{|c|}{ Projections } \\
\hline & \multicolumn{7}{|c|}{ (In millions of US dollars) } \\
\hline \multicolumn{8}{|l|}{ Poverty-Reducing expenditure 1 / } \\
\hline African Countries & $4,267.3$ & $4,210.3$ & $5,209.8$ & $6,192.7$ & $7,632.7$ & $8,581.0$ & $9,280.4$ \\
\hline Latin American Countries & $1,799.7$ & $1,825.4$ & $2,113.5$ & $2,186.4$ & $2,364.5$ & $2,508.7$ & $2,625.5$ \\
\hline Total & $6,066.9$ & $6,035.7$ & $7,323.3$ & $8,379.1$ & $9,997.2$ & $11,089.7$ & $11,905.9$ \\
\hline & \multicolumn{7}{|c|}{ (In percent) } \\
\hline \multicolumn{8}{|c|}{ Ratio of poverty-reducing expenditure to government revenue 2 / } \\
\hline African Countries & 38.6 & 41.9 & 47.6 & 50.7 & 53.1 & 53.8 & 52.7 \\
\hline Latin American Countries & 47.6 & 47.8 & 56.2 & 58.3 & 58.3 & 57.0 & 57.3 \\
\hline Total & 40.9 & 43.5 & 49.8 & 52.4 & 54.3 & 54.5 & 53.6 \\
\hline \multicolumn{8}{|c|}{ Ratio of poverty-reducing expenditure to GDP 2/ } \\
\hline African Countries & 5.5 & 5.7 & 6.8 & 7.5 & 8.3 & 8.6 & 8.6 \\
\hline Latin American Countries & 10.8 & 10.4 & 12.0 & 12.4 & 13.2 & 13.5 & 13.6 \\
\hline Total & 6.4 & 6.6 & 7.7 & 8.4 & 9.1 & 9.4 & 9.4 \\
\hline
\end{tabular}

Sources: HIPC country documents; and IMF staff estimates.

1/ Data are not available for all countries, particularly for 2003-05. In aggregation, the last available period was used for future years, thus understating the likely level of social spending.

2/ Weighted averages. 
$-83-$

Table 5. Poverty-Reducing Expenditures by Individual HIPCs that Have Reached the Decision Points — by Country (In millions of US dollars)

\begin{tabular}{|c|c|c|c|c|c|c|c|}
\hline & 1999 & 2000 & 2001 & 2002 & 2003 & 2004 & 2005 \\
\hline & \multicolumn{3}{|c|}{ Actual } & Estimate & \multicolumn{3}{|c|}{ Projections } \\
\hline \multicolumn{8}{|l|}{ Benin } \\
\hline Poverty-Reducing Expenditure & 114.5 & 110.2 & 161.0 & 162.2 & 179.9 & 197.2 & 214.2 \\
\hline Poverty-Reducing Expenditure/Government Revenue (in percent) & 30.0 & 29.2 & 41.7 & 35.4 & 34.1 & 34.5 & 33.9 \\
\hline Poverty-Reducing Expenditure/GDP (in percent) & 4.8 & 4.8 & 6.7 & 6.0 & 5.8 & 5.8 & 5.8 \\
\hline \multicolumn{8}{|l|}{ Bolivia } \\
\hline Poverty-Reducing Expenditure 1/ & 882.0 & 899.6 & 978.2 & 970.3 & 976.3 & 984.5 & 1016.9 \\
\hline Poverty-Reducing Expenditure/Government Revenue (in percent) & 44.8 & 48.2 & 52.8 & 55.1 & 55.3 & 50.8 & 50.2 \\
\hline Poverty-Reducing Expenditure/GDP (in percent) & 10.7 & 11.2 & 12.2 & 12.4 & 12.7 & 12.7 & 12.7 \\
\hline \multicolumn{8}{|l|}{ Burkina Faso } \\
\hline Poverty-Reducing Expenditure 2/ & 113.8 & 98.9 & 109.8 & 157.2 & 258.2 & 273.0 & 273.4 \\
\hline Poverty-Reducing Expenditure/Government Revenue (in percent) & 29.6 & 31.9 & 35.8 & 42.1 & 53.3 & 48.7 & 43.2 \\
\hline Poverty-Reducing Expenditure/GDP (in percent) & 4.0 & 3.8 & 3.9 & 5.0 & 6.5 & 6.5 & 6.0 \\
\hline \multicolumn{8}{|l|}{ Cameroon $3 /$} \\
\hline Poverty-Reducing Expenditure & 264.0 & 286.7 & 335.6 & 373.8 & 594.8 & 673.0 & 741.4 \\
\hline Poverty-Reducing Expenditure/Government Revenue (in percent) & 15.8 & 17.3 & 19.1 & 19.2 & 25.4 & 27.4 & 28.8 \\
\hline Poverty-Reducing Expenditure/GDP (in percent) & 2.9 & 3.2 & 3.9 & 3.6 & 4.9 & 5.1 & 5.3 \\
\hline Chad 3/ & & & & & & & \\
\hline Poverty-Reducing Expenditure 4/ & 190.0 & 149.0 & 191.7 & 235.5 & 320.3 & 366.6 & 403.5 \\
\hline Poverty-Reducing Expenditure/Government Revenue (in percent) & 149.8 & 164.9 & 153.1 & 149.0 & 146.0 & 94.5 & 86.2 \\
\hline Poverty-Reducing Expenditure/GDP (in percent) & 12.1 & 13.2 & 12.0 & 11.9 & 12.1 & 8.7 & 8.5 \\
\hline Democratic Republic of Congo 3/ & & & & & & & \\
\hline Poverty-Reducing Expenditure 5/ & $\ldots$ & 0.0 & 0.0 & 26.2 & 38.2 & 101.4 & 170.6 \\
\hline Poverty-Reducing Expenditure/Government Revenue (in percent) & $\cdots$ & 0.0 & 0.0 & 5.7 & 6.3 & 13.1 & 16.4 \\
\hline Poverty-Reducing Expenditure/GDP (in percent) & $\begin{array}{l}\cdots \\
\cdots \\
\end{array}$ & 0.0 & 0.0 & 0.5 & 0.7 & 1.7 & 2.6 \\
\hline Ethiopia 3/ & & & & & & & \\
\hline Poverty-Reducing Expenditure 6/ & 710.0 & 534.2 & 764.7 & 884.2 & 1158.4 & 1288.0 & 1388.6 \\
\hline Poverty-Reducing Expenditure/Government Revenue (in percent) & 60.9 & 43.6 & 63.6 & 72.8 & 81.8 & 87.3 & 84.0 \\
\hline Poverty-Reducing Expenditure/GDP (in percent) & 11.0 & 8.4 & 11.8 & 14.6 & 17.7 & 17.9 & 17.9 \\
\hline The Gambia 3/ & & & & & & & \\
\hline Poverty-Reducing Expenditure 7/ & 23.5 & 20.8 & 22.2 & 20.9 & 18.5 & 17.5 & 18.2 \\
\hline Poverty-Reducing Expenditure/Government Revenue (in percent) & 30.2 & 27.2 & 36.5 & 35.0 & 31.7 & 34.3 & 33.9 \\
\hline Poverty-Reducing Expenditure/GDP (in percent) & 5.4 & 5.0 & 5.9 & 5.9 & 5.9 & 6.2 & 6.3 \\
\hline Ghana 3/ & & & & & & & \\
\hline Poverty-Reducing Expenditure 8/ & 344.8 & 189.2 & 279.8 & 313.3 & 356.1 & 413.9 & 424.8 \\
\hline Poverty-Reducing Expenditure/Government Revenue (in percent) & 35.3 & 52.4 & 29.7 & 30.3 & 25.2 & 24.4 & 24.5 \\
\hline Poverty-Reducing Expenditure/GDP (in percent) & 4.4 & 7.2 & 5.3 & 5.1 & 5.0 & 5.4 & 5.2 \\
\hline Guinea 3/ & & & & & & & \\
\hline Poverty-Reducing Expenditure 9/ & 85.1 & 73.3 & 82.9 & 101.5 & 107.1 & 112.4 & 118.0 \\
\hline Poverty-Reducing Expenditure/Government Revenue (in percent) & 22.8 & 21.5 & 24.4 & 26.3 & 28.0 & 27.8 & 26.5 \\
\hline Poverty-Reducing Expenditure/GDP (in percent) & 2.5 & 2.4 & 2.7 & 3.2 & 3.2 & 3.2 & 3.2 \\
\hline Guinea-Bissau 3/ & & & & & & & \\
\hline Poverty-Reducing Expenditure 10/ & $\ldots$ & $\ldots$ & $\ldots$ & 6.3 & 8.5 & 8.4 & 9.7 \\
\hline Poverty-Reducing Expenditure/Government Revenue (in percent) & $\cdots$ & $\cdots$ & $\cdots$ & 20.3 & 20.3 & 20.3 & 20.3 \\
\hline Poverty-Reducing Expenditure/GDP (in percent) & $\ldots$ & $\ldots$ & $\ldots$ & 2.9 & 3.3 & 3.0 & 3.3 \\
\hline Guyana 3/ & & & & & & & \\
\hline Poverty-Reducing Expenditure 11/ & 87.0 & 105.2 & 117.7 & 123.9 & 124.7 & 129.2 & 135.6 \\
\hline Poverty-Reducing Expenditure/Government Revenue (in percent) & 43.6 & 52.0 & 53.6 & 53.2 & 50.5 & 47.6 & 48.2 \\
\hline Poverty-Reducing Expenditure/GDP (in percent) & 12.5 & 14.8 & 16.9 & 17.3 & 17.0 & 17.3 & 17.8 \\
\hline Honduras & & & & & & & \\
\hline Poverty-Reducing Expenditure 12/ & 487.7 & 476.4 & 638.4 & 697.2 & 841.2 & 946.2 & 1011.5 \\
\hline Poverty-Reducing Expenditure/Government Revenue (in percent) & 46.9 & 56.5 & 56.4 & 59.6 & 61.4 & 64.1 & 64.6 \\
\hline Poverty-Reducing Expenditure/GDP (in percent) & 9.0 & 10.2 & 10.0 & 10.6 & 12.1 & 12.8 & 12.9 \\
\hline Madagascar 3/ & & & & & & & \\
\hline Poverty-Reducing Expenditure /13 & 156.0 & 187.8 & 230.4 & 298.1 & 375.7 & 416.1 & 456.5 \\
\hline Poverty-Reducing Expenditure/Government Revenue (in percent) & 36.7 & 41.5 & 50.0 & 91.1 & 73.1 & 72.5 & 70.2 \\
\hline Poverty-Reducing Expenditure/GDP (in percent) & 4.2 & 4.8 & 5.0 & 6.6 & 7.7 & 8.0 & 8.1 \\
\hline Malawi 3/ & & & & & & & \\
\hline Poverty-Reducing Expenditure 14/ & 208.0 & 167.4 & 205.3 & 226.4 & 255.0 & 287.4 & 316.0 \\
\hline Poverty-Reducing Expenditure/Government Revenue (in percent) & 66.1 & 56.2 & 65.9 & 67.9 & 72.1 & 71.1 & 73.2 \\
\hline Poverty-Reducing Expenditure/GDP (in percent) & 11.5 & 9.8 & 12.2 & 11.9 & 14.3 & 14.7 & 15.0 \\
\hline Mali & & & & & & & \\
\hline Poverty-Reducing Expenditure 15/ & 103.4 & 150.0 & 134.7 & 184.5 & 271.3 & 271.7 & 292.8 \\
\hline Poverty-Reducing Expenditure/Government Revenue (in percent) & 24.3 & 39.5 & 31.3 & 33.0 & 38.2 & 34.8 & 34.0 \\
\hline Poverty-Reducing Expenditure/GDP (in percent) & 3.8 & 6.1 & 5.2 & 5.8 & 7.3 & 6.7 & 6.6 \\
\hline Mauritania & & & & & & & \\
\hline Poverty-Reducing Expenditure 16/ & 85.0 & 69.8 & 78.6 & 104.9 & 126.1 & 139.6 & 153.8 \\
\hline Poverty-Reducing Expenditure/Government Revenue (in percent) & 34.7 & 28.9 & 38.8 & 28.2 & 38.8 & 41.2 & 43.0 \\
\hline Poverty-Reducing Expenditure/GDP (in percent) & 9.0 & 7.3 & 8.0 & 10.6 & 11.4 & 11.7 & 12.0 \\
\hline Mozambique & & & & & & & \\
\hline Poverty-Reducing Expenditure 17/ & 543.0 & 688.3 & 676.4 & 674.5 & 791.9 & 851.0 & 893.0 \\
\hline Poverty-Reducing Expenditure/Government Revenue (in percent) & 52.8 & 156.6 & 166.6 & 133.5 & 134.9 & 126.4 & 116.9 \\
\hline Poverty-Reducing Expenditure/GDP (in percent) & 6.3 & 19.0 & 19.7 & 18.7 & 18.7 & 17.5 & 16.4 \\
\hline Nicaragua 3/ & & & & & & & \\
\hline Poverty-Reducing Expenditure 18/ & 342.9 & 344.2 & 379.3 & 395.0 & 428.4 & 463.1 & 508.2 \\
\hline Poverty-Reducing Expenditure/Government Revenue (in percent) & 60.1 & 59.5 & 68.4 & 67.1 & 62.7 & 62.4 & 64.2 \\
\hline Poverty-Reducing Expenditure/GDP (in percent) & 15.5 & 14.1 & 14.9 & 15.4 & 16.1 & 16.5 & 17.0 \\
\hline
\end{tabular}


Table 6. HIPC Initiative: Changes in the Estimates of Potential Costs by Creditor Group

(34 countries) $1 /$

\begin{tabular}{|c|c|c|c|c|}
\hline & \multirow{2}{*}{$\begin{array}{c}\text { September-2002 } \\
\text { Costing Exercise } \\
\text { 2001 NPV Terms } \\
\text { (In billions of U.S. dollars) }\end{array}$} & \multirow{2}{*}{$\begin{array}{c}\text { September-2003 } \\
\text { Costing Exercise } \\
2001 \text { NPV Terms 2/ } \\
\text { (In billions of U.S. dollars) }\end{array}$} & \multicolumn{2}{|c|}{$\begin{array}{c}\text { September-2003 } \\
\text { Costing Exercise } \\
\text { 2002 NPV Terms 2/ } \\
\end{array}$} \\
\hline & & & (In billions of U.S. dollars) & (In percent) \\
\hline Total costs & 37.2 & 37.3 & 39.4 & 100.0 \\
\hline Bilateral and commercial creditors & 19.2 & 19.3 & 20.4 & 51.7 \\
\hline Paris Club & 14.3 & 14.4 & 15.2 & 38.5 \\
\hline Other official bilateral & 3.2 & 3.2 & 3.4 & 8.6 \\
\hline Commercial & 1.6 & 1.7 & 1.8 & 4.6 \\
\hline Multilateral creditors & 17.9 & 18.0 & 19.0 & 48.3 \\
\hline World Bank & 8.2 & 8.3 & 8.7 & 22.2 \\
\hline Of which: IDA & 7.5 & 7.6 & 8.0 & 20.2 \\
\hline IBRD & 0.8 & 0.7 & 0.8 & 1.9 \\
\hline IMF & 2.7 & 2.8 & 2.9 & 7.5 \\
\hline $\mathrm{AfDB} / \mathrm{AfDF}$ & 3.2 & 3.1 & 3.3 & 8.4 \\
\hline $\mathrm{IaDB}$ & 1.2 & 1.2 & 1.3 & 3.2 \\
\hline Others & 2.6 & 2.6 & 2.8 & 7.1 \\
\hline \multicolumn{5}{|l|}{ Memorandum item: } \\
\hline Total costs including Liberia, Somalia, and Sudan & 46.0 & 47.4 & 50.0 & \\
\hline
\end{tabular}

Sources: HIPC country documents; and World Bank and IMF staff estimates.

1/ All HIPCs, excluding potentially sustainable cases (Angola, Kenya, Vietnam, and Yemen) and Liberia, Lao P.D.R., Somalia, and Sudan.

2/ Reflects: i) updated DSAs for Democratic Republic of Congo and Mali; and ii) updated assumption on the discount rate used in the NPV calculation, which has been revised from 6 to 5.45 percent. 
Table 7. HIPC Initiative: Breakdown of Estimated Potential Costs by Main Creditors and by Country Groups (In billions of U.S. dollars, in 2002 NPV terms) 1/

\begin{tabular}{|c|c|c|c|c|c|}
\hline & \multirow[b]{2}{*}{$\begin{array}{c}\text { Total } \\
\text { (34 countries) }\end{array}$} & \multicolumn{3}{|c|}{ Decision Point Cases (27) } & \multirow{2}{*}{$\begin{array}{c}\text { Post-2003 } \\
\text { Other } 4 / \\
\text { (7 countries) }\end{array}$} \\
\hline & & $\begin{array}{c}\text { Retroactive } 2 / \\
\text { (8 countries }) \\
\end{array}$ & $\begin{array}{l}\text { New cases } 3 / \\
\text { (19 countries) }\end{array}$ & $\begin{array}{c}\text { Total } \\
\text { (27 countries) }\end{array}$ & \\
\hline Total costs & 39.4 & 7.7 & 25.6 & 33.3 & 6.0 \\
\hline Bilateral and commercial creditors & 20.4 & 3.0 & 13.5 & 16.5 & 3.9 \\
\hline Paris Club & 15.2 & 2.3 & 10.1 & 12.5 & 2.7 \\
\hline Other official bilateral & 3.4 & 0.6 & 2.6 & 3.3 & 0.1 \\
\hline Commercial & 1.8 & 0.1 & 0.7 & 0.8 & 1.0 \\
\hline Multilateral creditors & 19.0 & 4.7 & 12.2 & 16.8 & 2.2 \\
\hline World Bank & 8.7 & 2.1 & 5.6 & 7.7 & 1.0 \\
\hline Of which: IDA & 8.0 & 2.1 & 5.3 & 7.4 & 0.6 \\
\hline IBRD & 0.8 & 0.0 & 0.3 & 0.3 & 0.4 \\
\hline IMF & 2.9 & 0.7 & 1.9 & 2.7 & 0.3 \\
\hline $\mathrm{AfDB} / \mathrm{AfDF}$ & 3.3 & 0.5 & 2.2 & 2.8 & 0.5 \\
\hline $\mathrm{IaDB}$ & 1.3 & 0.7 & 0.6 & 1.3 & 0.0 \\
\hline Others & 2.8 & 0.7 & 1.8 & 2.4 & 0.3 \\
\hline \multicolumn{6}{|l|}{ Memorandum item: } \\
\hline In percent of total costs & 100.0 & 19.6 & 65.1 & 84.7 & 15.3 \\
\hline
\end{tabular}

Sources: Country authorities; and World Bank and IMF staff estimates.

1/ All HIPCs, excluding potentially sustainable cases (Angola, Kenya, Vietnam, and Yemen) and Liberia, Lao P.D.R., Somalia, and Sudan.

2/ Benin, Bolivia, Burkina Faso, Guyana, Mali, Mozambique, Senegal, and Uganda. Côte d'Ivoire is a retroactive case but has not yet reached its enhanced decision point.

3/ Cameroon, Chad, Democratic Republic of Congo, Ethiopia, The Gambia, Ghana, Guinea, Guinea-Bissau, Honduras, Madagascar, Malawi, Mauritania, Nicaragua, Niger, Rwanda, São Tomé and Príncipe, Sierra Leone, Tanzania, and Zambia.

4/ Burundi, Central African Republic, Comoros, Republic of Congo, Côte d'Ivoire, Myanmar, and Togo. 
Table 8. HIPC Initiative: Estimates of Costs to Multilateral Creditors and Status of Their Commitment: (In millions of U.S. dollars, in 2002 NPV terms)

\begin{tabular}{|c|c|c|}
\hline Creditors & $\begin{array}{l}\text { Cost of Providing } \\
\text { HIPC Relief } \\
\text { (27 countries) }\end{array}$ & $\begin{array}{l}\text { Cost of Providing } \\
\text { HIPC Relief } \\
\text { (34 countries) }\end{array}$ \\
\hline Total & 16,839 & 19,010 \\
\hline Delivering or committed to delivering debt relief 1 / & 16,769 & 18,937 \\
\hline World Bank Group & 7,700 & 8,742 \\
\hline International Monetary Fund (IMF) & 2,677 & 2,935 \\
\hline African Development Bank (AfDB) & 2,772 & 3,297 \\
\hline Inter-American Development Bank (IaDB) & 1,250 & 1,250 \\
\hline Central American Bank for Economic Integration (CABEI) & 565 & 565 \\
\hline European Union/European Investment Bank (EU/EIB) & 663 & 773 \\
\hline International Fund for Agricultural Development (IFAD) & 268 & 294 \\
\hline Arab Bank for Economic Development in Africa (BADEA) & 187 & 230 \\
\hline OPEC Fund for International Development & 160 & 185 \\
\hline Islamic Development Bank (IsDB) & 136 & 144 \\
\hline Corporación Andina de Fomento (CAF) & 106 & 106 \\
\hline Arab Fund for Social and Economic Development (AFESD) & 71 & 71 \\
\hline Caricom Multilateral Clearing Facility (CMCF) & 66 & 66 \\
\hline West African Development Bank (BOAD) & 47 & 70 \\
\hline Fund for the Financial Development of the River Plate Basin (FONPLATA) & 28 & 28 \\
\hline Nordic Development Fund (NDF) & 25 & 25 \\
\hline Caribbean Development Bank (CDB) & 20 & 20 \\
\hline Arab Monetary Fund (AMF) & 13 & 13 \\
\hline Central Bank of West African States (BCEAO) & 6 & 37 \\
\hline Nordic Investment Bank (NIB) & 4 & 4 \\
\hline East African Development Bank (EADB) 2/ & 4 & 4 \\
\hline Banque des Etats de l'Afrique Centrale (BDEAC) & 1 & 4 \\
\hline Asian Development Bank (AsDB) & 0 & 75 \\
\hline Have not indicated intentions to provide relief under the HIPC Initiative & 71 & 72 \\
\hline Banque des Etats de l'Afrique Centrale (BEAC) & 35 & 35 \\
\hline Economic Community of West African States (ECOWAS) & 15 & 16 \\
\hline Eastern and Southern African Trade and Development Bank (PTA Bank) & 9 & 9 \\
\hline Banque de Dévelopment des Etats des Grands Lacs (BDEGL) & 6 & 6 \\
\hline Conseil de L'Entente (FEGECE) & 3 & 4 \\
\hline Fondo Centroamericano de Estabilizacion Monetaria (FOCEM) & 2 & 2 \\
\hline Fund for Solidarity and Economc Development (FSID) & 1 & 1 \\
\hline
\end{tabular}

Sources: HIPC country documents; country authorities; and World Bank staff estimates.

1/ Some of these creditors are providing relief on a case-by-case basis, and have yet to agree to participation in the entire HIPC Initiative. Moreover, for a few of these creditors, there have been significant delays in developing the modalities for the actual delivery of debt relief.

2/ The EADB Board has recently approved the Bank's participation in the HIPC Initiative. 
Table 9. HIPC Initiative: Status of Delivery of Assistance by the World Bank

(In millions of U.S. dollars, as of end-May 2003)

\begin{tabular}{|c|c|c|c|}
\hline Member & $\begin{array}{l}\text { Total committed debt } \\
\text { service reduction }\end{array}$ & $\begin{array}{l}\text { Debt service reduction } \\
\text { delivered } 1 /\end{array}$ & $\begin{array}{l}\text { Debt service reduction delivered } \\
\text { (in percent of total committed } \\
\text { reduction) }\end{array}$ \\
\hline \multicolumn{4}{|l|}{ Under the Original HIPC Initiative 2 / } \\
\hline Bolivia 3/ & 65.4 & 65.4 & 100.0 \\
\hline Burkina Faso 4/ & 182.8 & 182.8 & 100.0 \\
\hline Guyana 4/ & 60.8 & 60.8 & 100.0 \\
\hline Mali 5/ & 78.6 & 78.6 & 100.0 \\
\hline Mozambique 6/ & 975.0 & 975.0 & 100.0 \\
\hline Uganda 6/ & 354.5 & 354.5 & 100.0 \\
\hline Total Original HIPC & $1,717.0$ & $1,717.0$ & 100.0 \\
\hline \multicolumn{4}{|c|}{ Under the Enhanced HIPC Initiative 7/ } \\
\hline Benin & 124.3 & 19.3 & 15.5 \\
\hline Bolivia 8/ & 221.8 & 14.8 & 6.7 \\
\hline Burkina Faso 9/ & 236.7 & 20.5 & 8.7 \\
\hline Cameroon 10/ & 265.6 & 63.9 & 24.1 \\
\hline Chad & 106.7 & 9.9 & 9.2 \\
\hline Congo, Dem. Rep. of 11/ & 999.3 & 0.0 & 0.0 \\
\hline Ethiopia & 857.0 & 38.0 & 4.4 \\
\hline Gambia, The & 31.8 & 4.9 & 15.3 \\
\hline Ghana & $1,445.7$ & 51.3 & 3.6 \\
\hline Guinea & 233.6 & 27.1 & 11.6 \\
\hline Guinea-Bissau & 179.6 & 11.9 & 6.6 \\
\hline Guyana & 70.6 & 5.2 & 7.3 \\
\hline Honduras 12/ & 179.8 & 36.8 & 20.5 \\
\hline Madagascar & 436.7 & 37.6 & 8.6 \\
\hline Malawi & 588.5 & 44.8 & 7.6 \\
\hline Mali & 213.2 & 27.7 & 13.0 \\
\hline Mauritania & 172.8 & 18.1 & 10.5 \\
\hline Mozambique & 80.1 & 22.1 & 27.6 \\
\hline Nicaragua & 379.3 & 17.2 & 4.5 \\
\hline Niger & 301.7 & 23.9 & 7.9 \\
\hline Rwanda & 404.8 & 32.1 & 7.9 \\
\hline São Tomé and Príncipe & 44.9 & 3.4 & 7.6 \\
\hline Senegal & 160.1 & 41.1 & 25.7 \\
\hline Sierra Leone & 229.9 & 7.4 & 3.2 \\
\hline Tanzania & $1,157.1$ & 127.3 & 11.0 \\
\hline Uganda & 629.1 & 39.3 & 6.2 \\
\hline Zambia & 885.2 & 52.3 & 5.9 \\
\hline Total Enhanced HIPC & $10,635.7$ & 797.9 & 7.5 \\
\hline Grand Total & $12,352.8$ & $2,515.0$ & 20.4 \\
\hline
\end{tabular}

Sources: HIPC country documents; and World Bank staff estimates.

1/ Assistance is considered as provided: i) at the effective date of the purchase of IDA credits, the provision of IDA grants or prepayment of IBRD loan and ii) at the due date in the case of debt service reduction.

2/ These figures are from the respective completion point documents and include the reduction in interest payments associated with the cancellation c

loans, and the provision of grants instead of loans.

3/ Assistance to be provided through the reduction of the debt service to IDA.

4/ Assistance to be provided through the purchase by the HIPC Trust Fund of selected IDA credits.

5/ Assistance to be provided through the purchase by the HIPC Trust Fund of selected IDA credits and the reduction of the debt service to IDA.

6/ Assistance to be provided through the provision of IDA grants; the purchase by the HIPC Trust Fund of selected IDA credits and the reduction of the debt service to IDA.

7/ Unless otherwise indicated, assistance to be provided through the reduction of the debt service to IDA.

8/ Since the Original HIPC Initiative covered a significant share of debt service to IDA until June 2002, Bolivia started to benefit from significant amoun of assistance under the Enhanced HIPC Initiative only in July 2002.

9/ Includes topping up assistance.

10/ Assistance to be provided through: i) IDA grants, which would be used to cover 45 percent of IBRD debt service during

the interim period; ii) an IDA credit to prepay all IBRD outstanding debt at the completion point; and iii) a reduction

of IDA debt sevice falling due after the completion point.

11/ Corresponds to the assistance provided through the reduction of debt service payments to IDA on the disbursed and

outstanding debt as of end-2002. This mechanism would provide a relief of US\$609 million in NPV terms. The remaining

US\$223 million in NPV terms to cover the World Bank's share of assistance under the HIPC Initiative was provided

through the clearance of the arrears.

12/ Assistance to be provided through IDA grants and an IDA credit to prepay all IBRD outstanding debt at the completion point.

\section{CInternational Monetary Fund. Not for Redistribution}


Table 10. HIPC Initiative: Estimated Delivery of World Bank Assistance, 2000-09 (In millions of U.S. dollars)

\begin{tabular}{|c|c|c|c|c|c|c|c|c|c|c|}
\hline & \multicolumn{3}{|c|}{ Actual } & \multicolumn{7}{|c|}{ Projections } \\
\hline & 2000 & 2001 & 2002 & 2003 & 2004 & 2005 & 2006 & 2007 & 2008 & 2009 \\
\hline \multicolumn{11}{|l|}{ Debt service before HIPC relief } \\
\hline Benin & 11 & 12 & 15 & 16 & 17 & 19 & 20 & 21 & 22 & 23 \\
\hline Bolivia & 18 & 21 & 24 & 25 & 27 & 28 & 31 & 32 & 36 & 38 \\
\hline Burkina Faso & 13 & 15 & 19 & 20 & 20 & 22 & 23 & 23 & 24 & 25 \\
\hline Cameroon $1 /$ & 80 & 72 & 60 & 54 & 55 & 41 & 34 & 29 & 30 & 30 \\
\hline Congo, Dem. Rep. of & - & - & - & 35 & 36 & 38 & 41 & 45 & 47 & 48 \\
\hline Chad & - & 10 & 10 & 10 & 11 & 12 & 13 & 14 & 15 & 18 \\
\hline Ethiopia 1/ & 35 & 37 & 42 & 48 & 50 & 54 & 57 & 59 & 63 & 65 \\
\hline Gambia, The & 4 & 4 & 4 & 4 & 5 & 5 & 5 & 6 & 6 & 6 \\
\hline Ghana & - & 55 & 62 & 67 & 72 & 79 & 85 & 89 & 95 & 101 \\
\hline Guinea & 20 & 22 & 22 & 24 & 25 & 26 & 29 & 30 & 33 & 35 \\
\hline Guinea-Bissau & 4 & 5 & 5 & 6 & 6 & 7 & 7 & 7 & 7 & 8 \\
\hline Guyana 2/ & 8 & 9 & 8 & 8 & 8 & 7 & 7 & 7 & 7 & 7 \\
\hline Honduras & 49 & 36 & 33 & 29 & 22 & 21 & 20 & 17 & 16 & 7 \\
\hline Madagascar & 28 & 30 & 31 & 33 & 35 & 37 & 40 & 44 & 47 & 48 \\
\hline Malawi & - & 30 & 34 & 38 & 41 & 42 & 47 & 49 & 50 & 53 \\
\hline Mali & 20 & 23 & 26 & 27 & 30 & 32 & 35 & 36 & 38 & 39 \\
\hline Mauritania & 7 & 9 & 9 & 10 & 10 & 12 & 13 & 13 & 14 & 15 \\
\hline Mozambique & 20 & 21 & 23 & 27 & 31 & 35 & 36 & 38 & 40 & 42 \\
\hline Nicaragua & 12 & 11 & 9 & 9 & 11 & 13 & 14 & 14 & 15 & 17 \\
\hline Niger & 13 & 14 & 15 & 16 & 17 & 17 & 20 & 22 & 24 & 24 \\
\hline Rwanda & 12 & 14 & 16 & 17 & 18 & 19 & 21 & 21 & 22 & 23 \\
\hline São Tomé and Príncipe & - & 1 & 2 & 1 & 1 & 2 & 2 & 2 & 2 & 2 \\
\hline Senegal & 30 & 30 & 30 & 32 & 33 & 36 & 38 & 41 & 44 & 45 \\
\hline Sierra Leone & - & 5 & 6 & 8 & 10 & 10 & 11 & 11 & 11 & 11 \\
\hline Tanzania 1/ & 45 & 54 & 60 & 63 & 70 & 74 & 74 & 79 & 88 & 90 \\
\hline Uganda $1 /$ & 33 & 39 & 45 & 53 & 62 & 72 & 73 & 74 & 92 & 93 \\
\hline Zambia & 17 & 22 & 26 & 31 & 34 & 40 & 45 & 48 & 47 & 49 \\
\hline TOTAL & 478 & 601 & 634 & 710 & 757 & 799 & 837 & 869 & 934 & 962 \\
\hline \multicolumn{11}{|l|}{ Debt service after HIPC relief } \\
\hline Benin & 8 & 6 & 8 & 9 & 9 & 11 & 11 & 12 & 13 & 13 \\
\hline \multicolumn{11}{|l|}{ Bolivia } \\
\hline after: original HIPC relief & 0 & 1 & 17 & 25 & 27 & 28 & 31 & 32 & 36 & 38 \\
\hline enhanced HIPC relief & 0 & 0 & 9 & 12 & 13 & 14 & 15 & 16 & 18 & 19 \\
\hline \multicolumn{11}{|l|}{ Burkina Faso } \\
\hline after: original HIPC relief & 10 & 9 & 13 & 14 & 15 & 16 & 17 & 18 & 18 & 18 \\
\hline enhanced HIPC relief & 7 & 2 & 6 & 7 & 7 & 8 & 9 & 9 & 9 & 9 \\
\hline topping up & & & 6 & 6 & 6 & 7 & 7 & 7 & 7 & 7 \\
\hline Cameroon $1 /$ & 58 & 46 & 30 & 7 & 9 & 11 & 12 & 12 & 15 & 27 \\
\hline Congo, Dem. Rep. of & - & - & - & 19 & 4 & 4 & 4 & 5 & 5 & 5 \\
\hline Chad & - & 7 & 5 & 5 & 6 & 6 & 6 & 7 & 8 & 9 \\
\hline Ethiopia 1/ & 35 & 24 & 15 & 17 & 18 & 19 & 20 & 21 & 23 & 23 \\
\hline Gambia, The & 4 & 2 & 2 & 2 & 2 & 3 & 3 & 3 & 3 & 3 \\
\hline Ghana & - & 55 & 29 & 22 & 24 & 26 & 28 & 29 & 31 & 33 \\
\hline Guinea & 20 & 11 & 11 & 12 & 12 & 13 & 14 & 15 & 17 & 18 \\
\hline Guinea-Bissau & 4 & - & - & 0 & 1 & 1 & 1 & 1 & 1 & 1 \\
\hline \multicolumn{11}{|l|}{ Guyana } \\
\hline after: original HIPC relief & 7 & 7 & 6 & 7 & 6 & 5 & 5 & 5 & 5 & 5 \\
\hline enhanced HIPC relief & 7 & 5 & 4 & 4 & 4 & 2 & 2 & 2 & 2 & 2 \\
\hline Honduras & 39 & 18 & 9 & 3 & 1 & 1 & 1 & 1 & 1 & 1 \\
\hline Madagascar & 28 & 15 & 16 & 16 & 17 & 18 & 20 & 22 & 23 & 24 \\
\hline Malawi & - & 14 & 15 & 17 & 18 & 19 & 21 & 22 & 22 & 24 \\
\hline \multicolumn{11}{|l|}{ Mali } \\
\hline after: original HIPC relief & 18 & 19 & 22 & 24 & 26 & 29 & 31 & 33 & 34 & 36 \\
\hline enhanced HIPC relief & 16 & 9 & 11 & 12 & 14 & 15 & 16 & 18 & 18 & 19 \\
\hline Mauritania & 3 & 3 & 4 & 4 & 4 & 5 & 5 & 5 & 6 & 6 \\
\hline \multicolumn{11}{|l|}{ Mozambique } \\
\hline after: original HIPC relief & 9 & 10 & 10 & 13 & 14 & 16 & 16 & 17 & 18 & 20 \\
\hline enhanced HIPC relief & 2 & 4 & 4 & 5 & 6 & 6 & 7 & 7 & 7 & 16 \\
\hline Nicaragua & 12 & 6 & 1 & 1 & 1 & 1 & 1 & 1 & 2 & 2 \\
\hline Niger & 13 & 5 & 5 & 5 & 6 & 6 & 7 & 7 & 8 & 8 \\
\hline Rwanda & 12 & 2 & 2 & 2 & 2 & 2 & 2 & 2 & 3 & 3 \\
\hline São Tomé and Príncipe & - & - & - & - & 0 & 0 & 0 & 0 & 0 & 0 \\
\hline Senegal & 25 & 16 & 15 & 16 & 17 & 18 & 19 & 20 & 22 & 31 \\
\hline Sierra Leone & - & 5 & 2 & 1 & 1 & 1 & 1 & 1 & 1 & 1 \\
\hline
\end{tabular}


Table 11. HIPC Initiative: Status of Commitments by the IMF (In millions of SDRs, as of end-July 2003)

\begin{tabular}{|c|c|c|c|c|}
\hline Member & Decision Point & Completion Point & Amount Committed & Amount Disbursed 1/ \\
\hline \multicolumn{5}{|c|}{ Under the Original HIPC Initiative } \\
\hline Bolivia & Sep. 1997 & Sep. 1998 & 21.2 & 21.2 \\
\hline Burkina Faso & Sep. 1997 & Jul. 2000 & 16.3 & 16.3 \\
\hline Côte d'Ivoire 2/ & Mar. 1998 & -- & 16.7 & -- \\
\hline Guyana & Dec. 1997 & May. 1999 & 25.6 & 25.6 \\
\hline Mali & Sep. 1998 & Sep. 2000 & 10.8 & 10.8 \\
\hline Mozambique & Apr. 1998 & Jun. 1999 & 93.2 & 93.2 \\
\hline Uganda & Apr. 1997 & Apr. 1998 & 51.5 & 51.5 \\
\hline Total Original HIPC & & & 235.3 & 218.6 \\
\hline \multicolumn{5}{|c|}{ Under the Enhanced HIPC Initiative } \\
\hline Benin & Jul. 2000 & Mar. 2003 & 18.4 & 20.1 \\
\hline Bolivia & Feb. 2000 & Jun. 2001 & 41.1 & 44.2 \\
\hline Burkina Faso 3/ & Jul. 2000 & Apr. 2002 & 27.7 & 18.1 \\
\hline Cameroon & Oct. 2000 & Floating & 28.5 & 2.5 \\
\hline Chad & May. 2001 & Floating & 14.3 & 7.2 \\
\hline Congo, Democratic Rep. 4/ & Jul. 2003 & Floating & 228.3 & 1.1 \\
\hline Ethiopia & Nov. 2001 & Floating & 26.9 & 8.2 \\
\hline Gambia, The & Dec. 2000 & Floating & 1.8 & 0.1 \\
\hline Ghana & Feb. 2002 & Floating & 90.1 & 25.1 \\
\hline Guinea & Dec. 2000 & Floating & 24.2 & 5.2 \\
\hline Guinea-Bissau & Dec. 2000 & Floating & 9.2 & 0.5 \\
\hline Guyana & Nov. 2000 & Floating & 30.7 & 10.3 \\
\hline Honduras & Jun. 2000 & Floating & 22.7 & 4.5 \\
\hline Madagascar & Dec. 2000 & Floating & 16.6 & 5.0 \\
\hline Malawi & Dec. 2000 & Floating & 23.1 & 2.3 \\
\hline Mali & Sep. 2000 & Mar. 2003 & 34.7 & 38.5 \\
\hline Mauritania & Feb. 2000 & Jun. 2002 & 34.8 & 38.4 \\
\hline Mozambique & Apr. 2000 & Sep. 2001 & 13.7 & 14.8 \\
\hline Nicaragua & Dec. 2000 & Floating & 63.0 & 1.9 \\
\hline Niger & Dec. 2000 & Floating & 21.6 & 3.3 \\
\hline Rwanda & Dec. 2000 & Floating & 33.8 & 10.0 \\
\hline São Tomé and Príncipe & Dec. 2000 & Floating & -- & -- \\
\hline Senegal & Jun. 2000 & Floating & 33.8 & 13.2 \\
\hline Sierra Leone & Mar. 2002 & Floating & 98.5 & 47.3 \\
\hline Tanzania & Mar. 2000 & Nov. 2001 & 89.0 & 96.4 \\
\hline Uganda & Feb. 2000 & May. 2000 & 68.1 & 70.2 \\
\hline Zambia & Dec. 2000 & Floating & 468.8 & 351.6 \\
\hline Total Enhanced HIPC & & & $1,563.3$ & 839.9 \\
\hline Grand Total & & & $1,798.6$ & $1,058.5$ \\
\hline
\end{tabular}

Source: IMF Finance Department; also available at www.imf.org/external/fin.htm.

$1 /$ Includes interest on amounts committed.

2/ Equivalent to the committed amount of US\$22.5 million at decision point exchange rates (3/17/98).

3/ Includes commitment of additional enhanced HIPC assistance of SDR 10.93 million subject to receipt of satisfactory financing assurances from other creditors.

4/ Amount committed is equivalent to the remaining balance of the total IMF assistance of SDR 337.9 million, after deducting SDR 109.6 million representing the concessional element associated with the disbursement of a PRGF loan following the DRC's clearance of arrears to the IMF on June $12,2002$. 
Table 12. HIPC Initiative: Estimated Delivery of IMF Assistance, 1998-2010 1, (In millions of U.S. dollars)

\begin{tabular}{|c|c|c|c|c|c|c|c|c|c|c|c|c|c|}
\hline & \multicolumn{5}{|c|}{ Actual } & \multicolumn{8}{|c|}{ Projections } \\
\hline & 1998 & 1999 & 2000 & 2001 & 2002 & 2003 & 2004 & 2005 & 2006 & 2007 & 2008 & 2009 & 2010 \\
\hline \multicolumn{14}{|c|}{ IMF debt service before HIPC relief 2} \\
\hline Benin & 6 & 17 & 14 & 16 & 16 & 16 & 12 & 9 & 6 & 4 & 2 & 2 & 1 \\
\hline Bolivia & 42 & 34 & 31 & 32 & 30 & 29 & 36 & 32 & 25 & 18 & 11 & 2 & 0 \\
\hline Burkina Faso & 4 & 6 & 11 & 15 & 15 & 18 & 19 & 16 & 12 & 10 & 6 & 3 & 1 \\
\hline Cameroon & 20 & 20 & 21 & 5 & 3 & 6 & 20 & 33 & 40 & 40 & 36 & 22 & 9 \\
\hline Chad & 11 & 5 & 2 & 4 & 8 & 10 & 12 & 14 & 13 & 8 & 6 & 4 & 2 \\
\hline Congo, Democratic Rep. 3/ & 2 & 2 & 0 & 0 & 408 & 4 & 5 & 5 & 5 & 64 & 126 & 129 & 129 \\
\hline Ethiopia 4/ & 3 & 7 & 12 & 14 & 15 & 15 & 12 & 10 & 8 & 10 & 9 & 7 & 0 \\
\hline Gambia, The & 5 & 4 & 2 & 1 & 0 & 0 & 1 & 2 & 3 & 3 & 3 & 2 & 1 \\
\hline Ghana & 133 & 72 & 39 & 68 & 17 & 22 & 40 & 48 & 38 & 47 & 42 & 23 & 15 \\
\hline Guinea & 10 & 8 & 9 & 13 & 13 & 16 & 21 & 20 & 15 & 14 & 8 & 3 & 1 \\
\hline Guinea-Bissau & 1 & 1 & 1 & 1 & 2 & 3 & 3 & 3 & 3 & 2 & 1 & 1 & 1 \\
\hline Guyana & 22 & 22 & 26 & 17 & 17 & 17 & 18 & 16 & 14 & 9 & 6 & 2 & 0 \\
\hline Honduras & 3 & 7 & 10 & 14 & 44 & 42 & 15 & 26 & 22 & 22 & 21 & 13 & 0 \\
\hline Madagascar & 15 & 13 & 6 & 3 & 5 & 9 & 9 & 12 & 20 & 16 & 13 & 13 & 11 \\
\hline Malawi & 26 & 22 & 10 & 8 & 8 & 10 & 13 & 14 & 11 & 8 & 6 & 3 & 1 \\
\hline Mali & 12 & 13 & 19 & 24 & 29 & 29 & 29 & 25 & 18 & 12 & 8 & 4 & 1 \\
\hline Mauritania & 8 & 10 & 12 & 15 & 18 & 19 & 16 & 13 & 9 & 6 & 2 & 2 & 0 \\
\hline Mozambique & 25 & 32 & 31 & 29 & 24 & 20 & 21 & 23 & 21 & 16 & 11 & 4 & 0 \\
\hline Nicaragua & 1 & 4 & 7 & 7 & 7 & 9 & 17 & 26 & 26 & 26 & 24 & 13 & 1 \\
\hline Niger & 14 & 6 & 3 & 2 & 4 & 10 & 13 & 13 & 12 & 9 & 4 & 1 & 1 \\
\hline Rwanda & 4 & 9 & 13 & 12 & 7 & 3 & 6 & 10 & 12 & 12 & 10 & 7 & 3 \\
\hline São Tomé and Príncipe & 0 & 0 & 0 & 0 & 0 & 0 & 0 & 0 & 0 & 0 & 0 & 0 & 0 \\
\hline Sierra Leone & 1 & 13 & 27 & 78 & 31 & 32 & 21 & 8 & 5 & 13 & 12 & 12 & 12 \\
\hline Senegal & 63 & 34 & 25 & 31 & 30 & 40 & 48 & 42 & 32 & 22 & 13 & 9 & 3 \\
\hline Tanzania 4/ & 39 & 36 & 32 & 27 & 27 & 26 & 31 & 48 & 59 & 64 & 48 & 38 & 0 \\
\hline Uganda 4/ & 58 & 60 & 53 & 50 & 44 & 44 & 51 & 46 & 36 & 25 & 13 & 2 & 2 \\
\hline Zambia & 9 & 9 & 9 & 222 & 220 & 219 & 219 & 220 & 5 & 4 & 3 & 1 & 0 \\
\hline TOTAL & 535 & 469 & 424 & 706 & 1041 & 668 & 709 & 732 & 469 & 486 & 445 & 324 & 194 \\
\hline \multicolumn{14}{|c|}{ IMF debt service after Enhanced HIPC Initiative relief 2/ } \\
\hline Benin & 6 & 17 & 11 & 11 & 11 & 10 & 7 & 6 & 5 & 2 & 2 & 2 & 1 \\
\hline Bolivia & 36 & 23 & 21 & 23 & 19 & 18 & 18 & 18 & 18 & 17 & 11 & 2 & 0 \\
\hline Burkina Faso & 4 & 6 & 8 & 8 & 9 & 2 & 2 & 3 & 7 & 8 & 6 & 3 & 1 \\
\hline Cameroon & 20 & 20 & 20 & 4 & 3 & 4 & 14 & 24 & 32 & 32 & 30 & 17 & 7 \\
\hline Chad & 11 & 5 & 2 & 2 & 5 & 5 & 8 & 11 & 11 & 7 & 6 & 4 & 2 \\
\hline Congo, Democratic Rep. 3/ & 2 & 2 & 0 & 0 & 408 & 3 & 4 & 4 & 4 & 29 & 32 & 36 & 37 \\
\hline Ethiopia 4/ & 3 & 7 & 12 & 14 & 10 & 9 & 7 & 4 & 4 & 4 & 3 & 3 & 0 \\
\hline Gambia, The & 5 & 4 & 2 & 1 & 0 & 0 & 1 & 2 & 2 & 2 & 2 & 2 & 1 \\
\hline Ghana & 133 & 72 & 39 & 68 & 8 & 5 & 14 & 21 & 22 & 28 & 26 & 19 & 15 \\
\hline Guinea & 10 & 8 & 9 & 10 & 12 & 11 & 11 & 10 & 11 & 11 & 8 & 3 & 1 \\
\hline Guinea-Bissau & 1 & 1 & 1 & 0 & 2 & 0 & 1 & 0 & 0 & 0 & 0 & 0 & 1 \\
\hline Guyana & 22 & 15 & 17 & 6 & 10 & 6 & 6 & 6 & 6 & 6 & 6 & 2 & 0 \\
\hline Honduras & 3 & 7 & 10 & 12 & 39 & 35 & 10 & 22 & 18 & 20 & 21 & 13 & 0 \\
\hline Madagascar & 15 & 13 & 6 & 2 & 3 & 3 & 4 & 6 & 15 & 14 & 13 & 13 & 11 \\
\hline Malawi & 26 & 22 & 10 & 5 & 8 & 5 & 5 & 7 & 5 & 5 & 5 & 3 & 1 \\
\hline Mali & 12 & 13 & 18 & 17 & 19 & 18 & 16 & 13 & 10 & 6 & 4 & 4 & 1 \\
\hline Mauritania & 8 & 10 & 7 & 7 & 7 & 8 & 7 & 8 & 4 & 4 & 2 & 2 & 0 \\
\hline Mozambique & 25 & 18 & 0 & 2 & 6 & 6 & 7 & 7 & 5 & 5 & 5 & 3 & 0 \\
\hline Nicaragua & 1 & 4 & 7 & 7 & 6 & 5 & 6 & 2 & 6 & 7 & 6 & 5 & 1 \\
\hline Niger & 14 & 6 & 3 & 2 & 3 & 5 & 5 & 5 & 5 & 5 & 4 & 1 & 1 \\
\hline Rwanda & 4 & 9 & 13 & 4 & 3 & 1 & 2 & 1 & 4 & 4 & 4 & 4 & 3 \\
\hline São Tomé and Príncipe & 0 & 0 & 0 & 0 & 0 & 0 & 0 & 0 & 0 & 0 & 0 & 0 & 0 \\
\hline Sierra Leone & 1 & 13 & 27 & 78 & 2 & 2 & 2 & 1 & 1 & 1 & 1 & 1 & 1 \\
\hline Senegal & 63 & 34 & 23 & 26 & 25 & 31 & 35 & 30 & 26 & 22 & 13 & 9 & 3 \\
\hline Tanzania 4/ & 39 & 36 & 25 & 6 & 5 & 5 & 15 & 36 & 48 & 53 & 38 & 28 & 0 \\
\hline Uganda 4/ & 58 & 45 & 32 & 20 & 20 & 20 & 25 & 24 & 24 & 17 & 10 & 2 & 2 \\
\hline Zambia & 9 & 9 & 9 & 71 & 67 & 63 & 113 & 109 & 5 & 4 & 3 & 1 & 0 \\
\hline TOTAL & 530 & 422 & 333 & 406 & 708 & 281 & 343 & 380 & 298 & 317 & 262 & 182 & 89 \\
\hline
\end{tabular}


Table 12 (concluded). HIPC Initiative: Estimated Delivery of IMF Assistance, 1998-2010 1, (In millions of U.S. dollars)

\begin{tabular}{|c|c|c|c|c|c|c|c|c|c|c|c|c|c|}
\hline & \multicolumn{4}{|c|}{ Actual } & \multicolumn{9}{|c|}{ Projections } \\
\hline & 1998 & 1999 & 2000 & 2001 & 2002 & 2003 & 2004 & 2005 & 2006 & 2007 & 2008 & 2009 & 2010 \\
\hline \multicolumn{14}{|c|}{ IMF Original and Enhanced HIPC Initiative assistance 5/ } \\
\hline Benin & $\ldots$ & $\ldots$ & 2 & 5 & 5 & 6 & 5 & 2 & 1 & 1 & 0 & 0 & 0 \\
\hline Bolivia & 6 & 11 & 10 & 9 & 11 & 11 & 18 & 14 & 7 & 1 & 0 & 0 & 0 \\
\hline Burkina Faso & $\ldots$ & $\ldots$ & 3 & 6 & 6 & 15 & 17 & 14 & 5 & 2 & 0 & 0 & 0 \\
\hline Cameroon & $\ldots$ & $\ldots$ & 1 & 1 & 0 & 2 & 6 & 9 & 8 & 8 & 6 & 5 & 1 \\
\hline Chad & $\ldots$ & $\ldots$ & 0 & 2 & 3 & 5 & 5 & 3 & 2 & 1 & 0 & 0 & 0 \\
\hline Congo, Democratic Rep. 3/ & $\ldots$ & $\ldots$ & $\ldots$ & $\ldots$ & $\ldots$ & 1 & 2 & 2 & 2 & 35 & 95 & 94 & 92 \\
\hline Ethiopia 4/ & $\ldots$ & $\ldots$ & $\ldots$ & $\ldots$ & 5 & 6 & 6 & 5 & 4 & 7 & 6 & 4 & 0 \\
\hline Gambia, The & $\ldots$ & $\ldots$ & 0 & 0 & 0 & 0 & 0 & 0 & 1 & 1 & 1 & 0 & 0 \\
\hline Ghana & $\ldots$ & $\ldots$ & $\ldots$ & $\ldots$ & 9 & 17 & 26 & 27 & 16 & 19 & 16 & 4 & 0 \\
\hline Guinea & $\ldots$ & $\ldots$ & 0 & 3 & 1 & 5 & 10 & 10 & 5 & 3 & 0 & 0 & 0 \\
\hline Guinea-Bissau & $\ldots$ & $\ldots$ & 0 & 1 & 0 & 2 & 2 & 2 & 3 & 2 & 1 & 0 & 0 \\
\hline Guyana & $\ldots$ & 8 & 9 & 11 & 7 & 11 & 12 & 10 & 8 & 3 & 0 & 0 & 0 \\
\hline Honduras & $\ldots$ & $\ldots$ & 0 & 1 & 5 & 7 & 5 & 4 & 4 & 1 & 0 & 0 & 0 \\
\hline Madagascar & $\ldots$ & $\ldots$ & 0 & 1 & 2 & 5 & 4 & 6 & 5 & 2 & 0 & 0 & 0 \\
\hline Malawi & $\ldots$ & $\ldots$ & 0 & 3 & 0 & 5 & 8 & 7 & 6 & 3 & 1 & 0 & 0 \\
\hline Mali & $\ldots$ & $\ldots$ & 1 & 7 & 9 & 11 & 14 & 12 & 8 & 6 & 4 & 0 & 0 \\
\hline Mauritania & $\ldots$ & $\ldots$ & 5 & 8 & 11 & 11 & 8 & 5 & 5 & 2 & 0 & 0 & 0 \\
\hline Mozambique & $\ldots$ & 14 & 31 & 27 & 18 & 14 & 14 & 16 & 16 & 11 & 6 & 1 & 0 \\
\hline Nicaragua & $\ldots$ & $\ldots$ & 0 & 0 & 1 & 4 & 11 & 24 & 20 & 19 & 17 & 8 & 0 \\
\hline Niger & $\ldots$ & $\ldots$ & 0 & 1 & 1 & 5 & 8 & 8 & 7 & 4 & 0 & 0 & 0 \\
\hline Rwanda & $\ldots$ & $\ldots$ & 0 & 9 & 4 & 2 & 3 & 8 & 8 & 8 & 6 & 3 & 0 \\
\hline São Tomé and Príncipe & $\ldots$ & $\ldots$ & 0 & 0 & 0 & 0 & 0 & 0 & 0 & 0 & 0 & 0 & 0 \\
\hline Sierra Leone & $\ldots$ & $\ldots$ & $\ldots$ & $\ldots$ & 30 & 30 & 19 & 6 & 4 & 12 & 12 & 11 & 11 \\
\hline Senegal & $\ldots$ & $\ldots$ & 2 & 4 & 5 & 10 & 13 & 12 & 5 & 0 & 0 & 0 & 0 \\
\hline Tanzania 4/ & $\ldots$ & $\ldots$ & 7 & 21 & 22 & 21 & 16 & 12 & 12 & 11 & 11 & 10 & 0 \\
\hline Uganda 4/ & $\ldots$ & 15 & 21 & 29 & 24 & 24 & 26 & 22 & 12 & 8 & 2 & 0 & 0 \\
\hline Zambia & $\ldots$ & $\ldots$ & 0 & 151 & 154 & 156 & 107 & 111 & 0 & 0 & 0 & 0 & 0 \\
\hline TOTAL & 6 & 47 & 91 & 300 & 333 & 388 & 366 & 352 & 171 & 168 & 182 & 141 & 105 \\
\hline \multicolumn{14}{|l|}{$\begin{array}{l}\text { Memorandum item: } \\
\text { Average Annual Debt Service }\end{array}$} \\
\hline Reduction 6/ & $1 \%$ & $10 \%$ & $21 \%$ & $43 \%$ & $32 \%$ & $58 \%$ & $52 \%$ & $48 \%$ & $37 \%$ & $35 \%$ & $41 \%$ & $44 \%$ & $54 \%$ \\
\hline
\end{tabular}

1/ Under the Original and Enhanced HIPC Initiative.

2/ Obligations to the Fund as presented in the members' respective decision and completion point documents under the Enhanced HIPC Initiative, with revisions where necessary.

3/ The figures for 1998-2002 shown in the table represent actual payments made by the DRC to the IMF, including the settlement of its arrears on June 12, 2002.

4/ Fiscal year data.

$5 /$ Using SDR/U.S. dollar exchange rate at the completion point (for original HIPC assistance) or at the decision point (for enhanced HIPC assistance). Includes projected investment income $6 /$ Weighted average. 
Table 13. Status of Bilateral Donor Pledges to the HIPC Trust Fund

(Nominal amounts as of September 3, 2003, in millions of U.S. dollars)

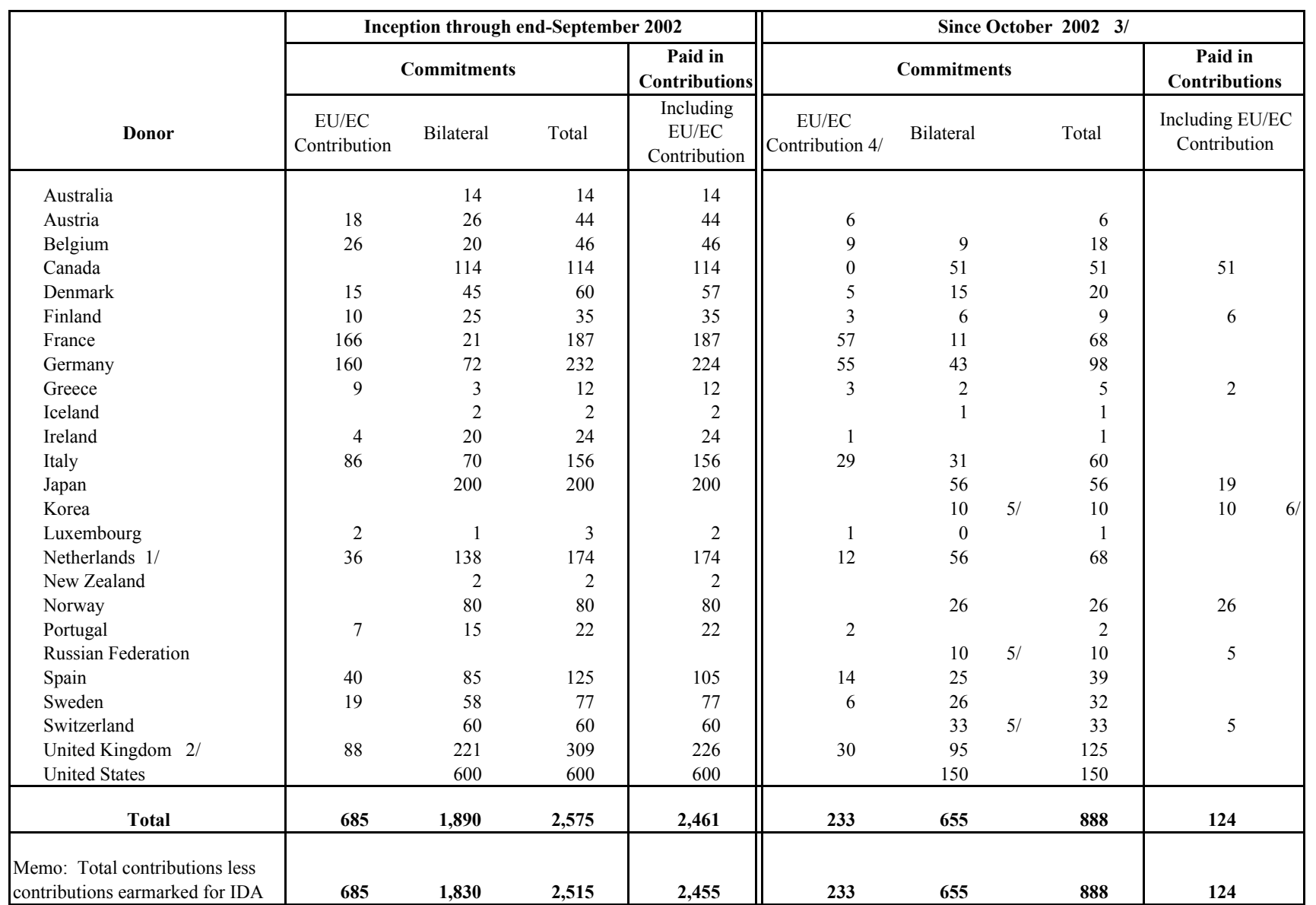

Source: IDA

Note: Many donors have also provided debt relief through other initiatives and mechanisms including: the Debt Reduction Facility for IDA-only Count (providing financing for commercial debt reduction), specific country-held multilateral debt relief facilities and the Central American Emergency Trust Fund. Bilateral donor funding for such measures has been (in \$ million) of: Spain-\$30; Norway-\$15.3; Netherlands-\$12.8; Switzerland-\$18.3; Italy-\$12; United Kingdom - \$16.3; Austria - \$2.7; Canada - \$5.4; Germany-\$13.2; Sweden-\$23.4; United States-\$25; and Denmark-\$10.9 (through a bilateral trust fund administered by IDB). These resources are not included herewith as the debt relief under HIPC is additional to these efforts. Figures in the table might not add up due to rounding.

1/ In addition, the Netherlands provided US\$20 million for debt relief provided by the IMF to Zambia over and above the debt relief called for under the HIPC Debt Initiative. This amount is not included in the contribution amount presented above.

2/ In addition, the United Kingdom contributed SDR31.5 million to the HIPC Trust Fund for the IMF for debt relief to Uganda. This amount is not included in the contribution amount presented above.

3/ These figures correspond to the Chairman's Summary of HIPC Technical Meeting of Oct. 24, 2002, adjusted to take into account the new EC-ACP contributions that were included as part of the EU Member States pledges. Subsequent contributions include Greece (EUR3 million) and Russia (US\$10 million). Many donors linked the level of their additional pledges to specific funding gap estimates.

4/ On May 16, 2003, the ACP-EU Council bringing together Ministers from African, Caribbean, and Pacific countries and EU Member States approved a new contribution to the HIPC Trust Fund of EUR200 million.

5/ Contribution agreements have been signed covering all of its outstanding balance.

6/ Promissory notes with encashment schedule. 
- $93-$

Table 14. HIPC Initiative: Estimated Paris Club Costs, by Creditor Country

(In millions of U.S. dollars, in 2002 NPV terms)

\begin{tabular}{|c|c|c|c|c|c|c|c|c|c|c|c|c|c|c|}
\hline & $\begin{array}{c}\text { Total: } \\
\text { (27 countries) }\end{array}$ & Benin & Bolivia & $\begin{array}{l}\text { Burkina } \\
\text { Faso }\end{array}$ & Cameroon & Chad & $\begin{array}{l}\text { Dem. } \\
\text { Rep. } \\
\text { Congo }\end{array}$ & Ethiopia & $\begin{array}{l}\text { The } \\
\text { Gambia }\end{array}$ & Ghana & Guinea & $\begin{array}{l}\text { Guinea- } \\
\text { Bissau }\end{array}$ & Guyana & Honduras \\
\hline Total & 12,454 & 69 & 464 & 26 & 958 & 15 & 3,278 & 424 & 5 & 828 & 170 & 167 & 201 & 188 \\
\hline Australia & 4 & - & - & - & - & - & - & 3 & - & - & - & - & - & - \\
\hline Austria & 229 & - & 11 & 2 & 80 & 0 & 34 & 2 & 2 & 14 & 2 & - & - & - \\
\hline Belgium & 550 & 1 & 26 & - & 37 & - & 398 & 1 & - & 1 & 1 & 4 & - & - \\
\hline Brazil 1/ & 215 & - & - & - & - & - & 1 & - & - & - & 1 & 7 & - & - \\
\hline \multirow[t]{2}{*}{ Canada } & 125 & 0 & 1 & - & 38 & - & 17 & 0 & - & 10 & - & - & 1 & 2 \\
\hline & & - & - & - & - & - & - & - & - & - & - & - & - & - \\
\hline Denmark & 24 & - & 0 & - & 17 & - & - & - & - & - & - & - & 1 & 1 \\
\hline Finland & 13 & - & - & - & 0 & - & - & 1 & - & 4 & - & - & - & - \\
\hline France & 2,173 & 29 & 22 & 12 & 463 & 12 & 658 & 2 & 2 & 50 & 90 & 5 & 1 & 6 \\
\hline Germany & 1,278 & 1 & 112 & - & 160 & 0 & 254 & 23 & - & 63 & 1 & 2 & 7 & 8 \\
\hline \multirow[t]{2}{*}{ Israel 1/ } & 6 & - & - & - & - & - & - & - & - & - & - & - & - & - \\
\hline & & - & - & - & - & - & - & - & - & - & - & - & - & - \\
\hline Italy & 1,073 & 11 & 24 & 3 & 39 & 1 & 321 & 51 & - & 17 & 8 & 90 & - & 17 \\
\hline Japan & 2,779 & 9 & 169 & - & 10 & - & 411 & 7 & - & 494 & 20 & - & 1 & 104 \\
\hline Netherlands, the & 326 & 4 & 10 & 3 & 8 & 0 & 160 & 0 & 0 & 44 & - & - & 5 & 3 \\
\hline Norway & 36 & 10 & - & - & - & - & 8 & - & 1 & - & 2 & - & - & 0 \\
\hline \multirow[t]{2}{*}{ Portugal } & 237 & - & - & - & - & - & - & - & - & - & - & 46 & - & - \\
\hline & & - & - & - & - & - & - & - & - & - & - & - & - & - \\
\hline Russia & 957 & 2 & - & 1 & - & 0 & - & 288 & - & - & 20 & 8 & 1 & - \\
\hline South Africa 1/ & 1 & - & - & - & - & - & - & - & - & - & - & - & - & - \\
\hline Spain & 437 & - & 51 & 5 & 27 & 2 & 12 & 6 & - & 25 & 2 & 6 & - & 33 \\
\hline Sweden & 88 & - & 1 & - & 14 & - & 42 & 9 & - & 15 & - & - & - & - \\
\hline \multirow[t]{2}{*}{ Switzerland } & 29 & - & - & - & 9 & - & 8 & - & - & - & - & - & - & 1 \\
\hline & & - & - & - & - & - & . & - & - & - & - & - & & \\
\hline Trinidad and Tobago 1/ & 120 & - & - & - & - & - & - & - & - & - & - & - & 120 & - \\
\hline United Kingdom & 528 & 2 & 11 & 1 & 39 & - & 71 & 4 & - & 72 & 1 & - & 52 & - \\
\hline United States & 1,227 & 0 & 26 & - & 14 & - & 883 & 28 & - & 19 & 21 & - & 13 & 14 \\
\hline
\end{tabular}


$-94-$

Table 14 (concluded). HIPC Initiative: Estimated Paris Club Costs, by Creditor Country

(In millions of U.S. dollars, in 2002 NPV terms)

\begin{tabular}{|c|c|c|c|c|c|c|c|c|c|c|c|c|c|c|}
\hline & Madagascar & Malawi & Mali & Mauritania & Mozambique & Nicaragua & Niger & Rwanda & $\begin{array}{l}\text { São Tomé } \\
\text { \& Príncipe }\end{array}$ & Senegal & $\begin{array}{l}\text { Sierra } \\
\text { Leone }\end{array}$ & Tanzania & Uganda & Zambia \\
\hline Total & 426 & 144 & 126 & 153 & 1,158 & 968 & 117 & 38 & 22 & 140 & 188 & 838 & 133 & 1,211 \\
\hline Australia & - & - & - & - & - & 1 & - & - & - & - & - & - & - & - \\
\hline Austria & 8 & 8 & - & 23 & 8 & 1 & - & 2 & - & - & 0 & 16 & 13 & 4 \\
\hline Belgium & 8 & - & - & - & - & - & - & - & 1 & 2 & 8 & 63 & - & - \\
\hline Brazil 1/ & - & - & - & 8 & 93 & 34 & - & - & - & - & - & 44 & - & 27 \\
\hline Canada & 7 & - & - & - & - & - & - & 2 & - & 1 & - & 18 & - & 27 \\
\hline Denmark & - & - & - & - & - & - & - & - & - & 4 & - & - & - & - \\
\hline Finland & - & - & - & - & - & 6 & - & - & - & - & - & - & 2 & - \\
\hline France & 102 & 5 & 71 & 58 & 224 & 39 & 83 & 24 & 3 & 55 & 13 & 56 & 13 & 77 \\
\hline Germany & 19 & 0 & - & 2 & 90 & 251 & - & - & 4 & 17 & 7 & 37 & 1 & 219 \\
\hline Israel 1/ & 0 & - & - & - & - & 1 & - & - & - & - & - & - & 5 & - \\
\hline Italy & 33 & - & 0 & 0 & 203 & 48 & - & - & 5 & 16 & 33 & 74 & 39 & 39 \\
\hline Japan & 151 & 127 & 29 & 32 & 69 & 114 & 16 & 10 & - & 22 & 54 & 346 & 29 & 555 \\
\hline Netherlands, the & - & - & 1 & 11 & - & 19 & - & - & - & 3 & 16 & 39 & - & 0 \\
\hline Norway & - & - & - & - & - & - & - & - & - & 5 & 5 & 4 & 0 & - \\
\hline Portugal & - & - & - & - & 185 & - & - & - & 6 & - & - & - & - & - \\
\hline Russia & 53 & - & 22 & - & 180 & 277 & - & - & 1 & - & - & 55 & - & 51 \\
\hline South Africa 1/ & - & 1 & - & - & - & - & - & - & - & - & - & - & - & - \\
\hline Spain & 28 & 3 & - & 13 & 26 & 146 & 6 & - & 3 & 10 & - & 9 & 23 & - \\
\hline Sweden & 3 & - & - & - & 4 & - & - & - & - & 0 & - & - & - & - \\
\hline Switzerland & 1 & - & - & - & - & 1 & - & - & - & - & 9 & - & - & - \\
\hline Trinidad and Tobago 1/ & - & - & - & - & - & - & - & - & - & - & - & - & - & - \\
\hline United Kingdom & 7 & 0 & 3 & 3 & 56 & 1 & 7 & - & - & 0 & 2 & 70 & 8 & 118 \\
\hline United States & 6 & - & 0 & 1 & 20 & 29 & 4 & 0 & - & 5 & 40 & 8 & 0 & 95 \\
\hline
\end{tabular}

Sources: HIPC country documents; and IMF staff estimates

Note: The total cost attributable to the group of Paris Club creditors is obtained from HIPC country documents. The distribution of costs among Paris Club creditors is estimated on the basis of each creditor's exposure to the debt stock that remains after the delivery of traditional debt relief, which is a burden-sharing principle commonly used in the HIPC Initiative. However, the Paris Club may decide to distribute the debt relief burden differently among its members, by taking into account the exposure to pre-cutoff debt and post-cutoff debt, and ODA and non-ODA debt.

1/ Creditor invited on a case-by-case basis. 
Table 15. HIPC Initiative: Paris Club Debt Relief 1/

Status as of July 2003

\begin{tabular}{|c|c|c|c|c|c|}
\hline Country & $\begin{array}{c}\text { Date of } \\
\text { Enhanced } \\
\text { Decision/ } \\
\text { Completion } \\
\text { Point } \\
\end{array}$ & $\begin{array}{l}\text { Interim } \\
\text { Relief } \\
\text { Provided? }\end{array}$ & $\begin{array}{l}\text { Topping up or } \\
\text { New } \\
\text { Rescheduling }\end{array}$ & $\begin{array}{l}\text { Date of Paris } \\
\quad \text { Club } \\
\text { Rescheduling }\end{array}$ & Comments \\
\hline \multicolumn{6}{|c|}{ 1. Enhanced completion point reached } \\
\hline Benin & Mar-03 & yes & $\begin{array}{l}\text { new } \\
\text { rescheduling }\end{array}$ & Apr-03 & $\begin{array}{l}\text { Enhanced completion point March 2003. Paris Club operation on stock on Cologne } \\
\text { terms on April 23, } 2003 .\end{array}$ \\
\hline Bolivia & Feb-00 & yes & $\begin{array}{c}\text { new } \\
\text { rescheduling }\end{array}$ & Jul-01 & $\begin{array}{l}\text { Enhanced completion point June 2001. Paris Club stock operation on Cologne terms } \\
\text { July } 10,2001 \text {. No interim relief beyond original HIPC relief from the Paris Club. }\end{array}$ \\
\hline Burkina Faso & Jul-00 & yes & $\begin{array}{c}\text { new } \\
\text { rescheduling }\end{array}$ & Jun-02 & $\begin{array}{l}\text { As the decision point under the enhanced HIPC Initiative and the completion point } \\
\text { under the original framework were reached on the same day, creditors decided not to } \\
\text { grant a stock operation but a flow rescheduling on Lyon terms to Burkina Faso. } \\
\text { Enhanced completion point April 2002. On June 19, } 2002 \text { creditors agreed to a stock } \\
\text { treatment on Cologne terms, and in principle, to provide topping-up relief. Regarding } \\
\text { the method of topping up, it was agreed in December } 2002 \text { that the share in topping up } \\
\text { would take account of any additional bilateral debt relief. }\end{array}$ \\
\hline Mali & Mar-03 & yes & $\begin{array}{c}\text { new } \\
\text { rescheduling }\end{array}$ & Mar-03 & $\begin{array}{l}\text { Enhanced completion point March 2003. Paris Club operation on stock on Cologne } \\
\text { terms on March 12, } 2003 .\end{array}$ \\
\hline Mauritania & Feb-00 & yes & $\begin{array}{c}\text { new } \\
\text { rescheduling }\end{array}$ & Jul-02 & $\begin{array}{l}\text { Enhanced completion point June 2002; Paris Club stock operation on Cologne terms on } \\
\text { July } 8,2002 \text {. }\end{array}$ \\
\hline Mozambique & Apr-00 & yes & $\begin{array}{c}\text { new } \\
\text { rescheduling }\end{array}$ & Nov-01 & $\begin{array}{l}\text { Enhanced completion point September 2001. Paris Club stock operation on Cologne } \\
\text { terms. }\end{array}$ \\
\hline Tanzania & Apr-00 & yes & $\begin{array}{c}\text { new } \\
\text { rescheduling }\end{array}$ & Jan-02 & $\begin{array}{l}\text { Enhanced completion point November 2001. Paris Club stock operation on Cologne } \\
\text { terms on January 14, 2002. Arrears outstanding at end-March } 2000 \text { and maturities on } \\
\text { pre-cutoff date debt falling due during April 2000-March } 2003 \text { were rescheduled on } \\
\text { Cologne terms. Exempt were arrears accrued since the end of the consolidation period } \\
\text { (end-November 1999) of the } 1997 \text { rescheduling, which were paid by end-November } \\
\text { 2000. In a side letter, Japan agreed to a deferral over } 3 \text { years of maturities due under } \\
\text { the } 1997 \text { rescheduling in light of the continuing delays in signing the bilateral } \\
\text { agreement. }\end{array}$ \\
\hline Uganda & Feb-00 & yes & $\begin{array}{c}\text { new } \\
\text { rescheduling }\end{array}$ & Sep-00 & $\begin{array}{l}\text { Enhanced completion point May 2000; Paris Club stock operation on Cologne terms } \\
\text { September 11,2000; no interim relief from the Paris Club beyond original HIPC relief } \\
\text { because of the short time period between decision and completion points. }\end{array}$ \\
\hline
\end{tabular}

\section{Other retroactive cases}

2a. No assistance under original framework

\begin{tabular}{|c|c|c|c|c|c|}
\hline Senegal & Jun-00 & yes & topping up & Oct-00 & $\begin{array}{l}70 \text { percent of payments falling on non-ODA due between July 12, } 2000 \text { and April } 19 \text {, } \\
2002 \text { on the } 1995 \text { Naples flow rescheduling and the } 1998 \text { Naples stock operation were } \\
\text { canceled or rescheduled. In the case of creditors that rescheduled, moratorium interest } \\
\text { on the rescheduling was capitalized; at the completion point, the rescheduled amounts } \\
\text { and capitalized moratorium interest will be treated so as to secure comparable } \\
\text { treatment with the creditors that cancelled debt. In April 2003, the Paris Club decided } \\
\text { to extend the terms of the } 1998 \text { Paris Club agreement to cover the period of the } \\
\text { arrangement until the time of the expected HIPC completion point around the end of } \\
2003 \text {. }\end{array}$ \\
\hline \multicolumn{6}{|c|}{ 2b. After completion point under original framework } \\
\hline Guyana & Nov-00 & yes & n.a. & Jun-99 & $\begin{array}{l}\text { Guyana was granted a stock-of-debt reduction on Lyon terms reaching the completion } \\
\text { point under the original framework. Of the stock of pre-cutoff date medium- and long- } \\
\text { term public debt, } 65 \text { percent was topped up from a } 67 \text { percent to an } 80 \text { percent NPV } \\
\text { reduction. No additional interim relief. }\end{array}$ \\
\hline Guyana & Nov-00 & no & n.a. & n.a. & $\begin{array}{l}\text { On June } 25,1999 \text {, Guyana was granted a stock-of-debt reduction on Lyon terms after } \\
\text { reaching the original completion point. Of the stock of pre-cutoff date medium- and } \\
\text { long-term public debt, } 65 \text { percent was topped up from a } 67 \text { percent to an } 80 \text { percent } \\
\text { NPV reduction. No additional interim relief. }\end{array}$ \\
\hline
\end{tabular}

\section{CInternational Monetary Fund. Not for Redistribution}


Table 15 (concluded). HIPC Initiative: Paris Club Debt Relief 1/ Status as of July 2003

\begin{tabular}{|c|c|c|c|c|c|}
\hline Country & $\begin{array}{l}\text { Date of } \\
\text { Enhanced } \\
\text { Decision } \\
\text { Point }\end{array}$ & $\begin{array}{l}\text { Interim } \\
\text { Relief } \\
\text { Provided? }\end{array}$ & $\begin{array}{l}\text { Topping up or } \\
\text { New } \\
\text { Rescheduling }\end{array}$ & $\begin{array}{l}\text { Date of Paris } \\
\text { Club } \\
\text { Rescheduling }\end{array}$ & Comments \\
\hline \multicolumn{6}{|c|}{ 3. New decision point cases } \\
\hline Cameroon & Oct- 00 & yes & new rescheduling & Jan-01 & $\begin{array}{l}\text { Arrears on pre-cutoff date debt accumulated during October-December } 2000 \text { and all } \\
\text { maturities on pre-cutoff date debt falling due during January 2001-December } 2003 \text { were } \\
\text { rescheduled on Cologne terms ( } 90 \text { percent debt reduction). Arrears outstanding at end- } \\
\text { September were rescheduled on Naples terms ( } 67 \text { percent debt reduction). }\end{array}$ \\
\hline Chad & May-01 & yes & new rescheduling & Jun-01 & $\begin{array}{l}\text { Arrears on pre-cutoff date debt at April 30,2001 were rescheduled on Naples terms. } \\
\text { Maturities on all pre-cutoff date debt falling due during May 2001-March } 2003 \text { were } \\
\text { rescheduled on Cologne terms. In April 2003, the Paris Club decided to extend the } \\
\text { consolidation period under the } 2001 \text { agreement until the end of the current PRGF } \\
\text { arrangement. }\end{array}$ \\
\hline $\begin{array}{l}\text { Democratic Republic of } \\
\text { Congo }\end{array}$ & Jul-03 & n.a. & n.a. & Sep-03 & $\begin{array}{l}\text { The Paris Club agreed in September } 2002 \text { to a rescheduling on Naples terms covering the } \\
\text { period from } 1 \text { July } 2002 \text { up to } 30 \text { June } 2005 \text {. Paris Club creditors also agreed to consider a } \\
\text { topping-up to Cologne terms as soon as the Democratic Republic of Congo has reached its } \\
\text { decision point. }\end{array}$ \\
\hline Ethiopia & Nov-01 & yes & topping up & Apr-02 & Paris Club agreed to provide a topping up to Cologne terms from existing Naples terms. \\
\hline Gambia, The & Dec-00 & yes & n.a. & Jan-03 & $\begin{array}{l}\text { Paris Club provided a Cologne flow rescheduling on the maturities falling due from July } 17 \text {, } \\
2002 \text { to July } 17,2005 \text {. }\end{array}$ \\
\hline Ghana & Feb-02 & yes & new rescheduling & May-02 & $\begin{array}{l}\text { Creditors established a new cut-off date, thus increasing the amounts treated concessionally, } \\
\text { and agreed to a flow rescheduling of arrears and maturities on pre-cutoff date debt, under } \\
\text { Cologne terms through the end of PRGF in Nov. 2002. In March } 2003 \text {, it was agreed to } \\
\text { extend the consolidation period for debt relief under the May } 2002 \text { agreement from } \\
\text { November } 2002 \text { to April } 2004 \text {, in anticipation of a new PRGF arrangement and to provide } \\
\text { financing assurances for that arrangement. }\end{array}$ \\
\hline Guinea & Dec-00 & yes & new rescheduling & May-01 & $\begin{array}{l}\text { Maturities on pre-cutoff, non-ODA debt falling due during December } 2000-\text { March } 2004 \\
\text { were rescheduled on Cologne terms }(90 \text { percent debt reduction). Arrears on pre-cutoff date } \\
\text { debt outstanding at end-November } 2000 \text { were rescheduled on Naples terms ( } 67 \text { percent debt } \\
\text { reduction). In June } 2003 \text {, the Paris Club agreed that in the absence of a Fund-supported } \\
\text { program the third phase of the } 2001 \text { agreement will not enter into force. }\end{array}$ \\
\hline Guinea-Bissau & Dec-00 & yes & new rescheduling & Jan-01 & $\begin{array}{l}\text { Maturities on pre-cutoff date debt falling due during December } 2000 \text {-December } 2003 \text { were } \\
\text { rescheduled on Cologne terms (except the payments on a deferral in the context of the } 1995 \\
\text { agreement, which were deferred again on nonconcessional terms). Arrears on pre-cutoff date } \\
\text { debt were rescheduled on Naples terms ( } 67 \text { percent debt reduction). Arrears on post-cutoff } \\
\text { date debt received varying levels of debt reduction. However, in January } 2003 \text { the Paris Clu } \\
\text { decided in view of the longstanding nature of the country's off-track performance on the } \\
\text { explicit non-entry into force of the phases envisioned under the Paris Club agreement. }\end{array}$ \\
\hline Honduras & Jul-00 & yes & $\begin{array}{l}\text { n.a. - see } \\
\text { comments }\end{array}$ & Apr-99 & $\begin{array}{l}\text { Given the fact that Honduras had been granted a total payment deferral during November } \\
1998 \text {-March } 2002 \text { following Hurricane Mitch, creditors considered that interim relief had } \\
\text { already been provided to Honduras. Creditors agreed to consider Honduras for a Cologne } \\
\text { flow rescheduling in the context of a PRGF arrangement. }\end{array}$ \\
\hline Madagascar & Dec-00 & yes & new rescheduling & Mar-01 & $\begin{array}{l}\text { Maturities on all pre-cutoff date debt falling due during December 2000-February } 2004 \\
\text { were rescheduled on Cologne terms. }\end{array}$ \\
\hline Malawi & Dec-00 & yes & new rescheduling & Jan-01 & $\begin{array}{l}\text { Maturities on all pre-cutoff date debt falling due during December } 2000-\text { December } 2003 \\
\text { were rescheduled on Cologne terms. Also, creditors moved the cutoff date from January } 1 \text {, } \\
1982 \text { to January } 1,1997 \text {, which made all of Malawi's debt pre-cutoff date debt. However, in } \\
\text { January } 2003 \text { the Paris Club decided in view of the longstanding nature of the country's off- } \\
\text { track performance on the explicit non-entry into force of the phases envisioned under the } \\
\text { Paris Club agreement. }\end{array}$ \\
\hline Nicaragua & Dec-00 & yes & new rescheduling & Dec-02 & $\begin{array}{l}\text { Nicaragua was granted a total payment deferral during December } 1998-\text { February } 2001 \\
\text { following Hurricane Mitch. In December 2002, creditors agreed to grant Nicaragua a flow } \\
\text { rescheduling on Cologne terms, covering the } 3 \text { years of the PRGF-supported program } \\
\text { approved on December } 4,2002 \text {. Under the agreement, all pre-cutoff debt, including the } \\
\text { amounts deferred after Hurricane Mitch, will be rescheduled on Cologne terms. Creditors } \\
\text { also expressed their readiness to provide a Cologne stock treatment as soon as Nicaragua } \\
\text { reaches the completion point under the Enhanced HIPC Initiative. }\end{array}$ \\
\hline Niger & Dec-00 & yes & new rescheduling & Jan-01 & $\begin{array}{l}\text { Maturities on all pre-cutoff date debt falling due during December } 2000-\text { December } 2003 \\
\text { were rescheduled on Cologne terms. Arrears on pre-cutoff date debt were rescheduled on } \\
\text { Naples terms ( } 67 \text { percent reduction). Arrears on post-cutoff date debt received varying level } \\
\text { of debt reduction. }\end{array}$ \\
\hline Rwanda & Dec-00 & yes & topping up & TOR & $\begin{array}{l}\text { The April } 2000 \text { Paris Club rescheduling agreement on Naples terms was topped up to } \\
\text { Cologne terms (by mail) for the period December 2000-April 2002, which was subsequently } \\
\text { extended until the end of } 2003\end{array}$ \\
\hline São Tomé and Príncipe & Dec-00 & $\begin{array}{c}\text { to be } \\
\text { provided }\end{array}$ & topping up & TOR & $\begin{array}{l}\text { The Paris Club agreed in May } 2000 \text { to a rescheduling on Naples terms. However, phases } 2 \\
\text { and } 3 \text { covering the period from May } 2001 \text { until April } 2003 \text { did not take effect because of } \\
\text { PRGF interruptions. In July } 2003 \text {, the Paris Club considered extending this agreement to } \\
\text { cover the period under a new PRGF arrangement, or negotiating a new agreement on } \\
\text { Cologne terms. }\end{array}$ \\
\hline Sierra Leone & Mar-02 & yes & topping up & Jul-02 & $\begin{array}{l}\text { The October } 2001 \text { Paris Club rescheduling on Naples terms was topped up to Cologne terms } \\
\text { after Sierra Leone reached the Decision Point (covering maturities falling due on pre-cutoff } \\
\text { date debt during March 2002- September 2004). }\end{array}$ \\
\hline Zambia & Dec-00 & yes & topping up & Sep-02 & $\begin{array}{l}\text { The April } 1999 \text { Paris Club rescheduling agreement on Naples terms was topped up to } \\
\text { Cologne terms, covering maturities on pre-cutoff date debt falling due during Jan 2001- } \\
\text { March 2003. In June 2003, the Paris Club agreed to extend the consolidation period to cover } \\
\text { the period of a new PRGF arrangement. }\end{array}$ \\
\hline
\end{tabular}

1/ For the 27 countries that have already reached the decision points under the Enhanced HIPC Initiative.

\section{(C)International Monetary Fund. Not for Redistribution}


Table 16: Paris Club Creditors' Delivery of Debt Relief Under Bilateral Initiatives Beyond the HIPC Initiative

\begin{tabular}{|c|c|c|c|c|c|c|c|}
\hline & Countries covered & ODA (in & ercent) & Non-ODA ( & percent) & Provision of $\mathrm{rc}$ & elief \\
\hline & & Pre-cutoff date debt & Post-cutoff date debt & Pre-cutoff date debt & Post-cutoff date debt & $\begin{array}{r}\text { Decision point } \\
\text { (In percent) }\end{array}$ & $\begin{array}{r}\text { Completion } \\
\text { point }\end{array}$ \\
\hline & (1) & (2) & (3) & (4) & (5) & (6) & (7) \\
\hline Australia & HIPCs & 100 & 100 & 100 & $100 \mathrm{l} /$ & 1/ & 1/ \\
\hline Austria & HIPCs & 100 & 100 & 100 & - & 100 flow & Stock \\
\hline Belgium & HIPCs & 100 & 100 & 100 & - & 100 flow & Stock \\
\hline Canada & HIPCs 2/ & $-3 /$ & $-3 /$ & 100 & 100 & 100 flow & Stock \\
\hline Denmark & HIPCs & 100 & $1004 /$ & 100 & $1004 /$ & 100 flow & Stock \\
\hline France & HIPCs & 100 & 100 & 100 & - & 100 flow $5 /$ & Stock \\
\hline Finland & HIPCs & 100 & 100 & $-6 /$ & $-6 /$ & - & - \\
\hline Germany & HIPCs & 100 & 100 & 100 & - & 100 flow & Stock \\
\hline Ireland & - & - & - & - & - & - & - \\
\hline Italy & HIPCs & 100 & $1007 /$ & 100 & $1007 /$ & 100 flow & Stock \\
\hline Japan & HIPCs & 100 & 100 & 100 & - & - & Stock \\
\hline Netherlands, the & HIPCs & 100 & 100 & 100 & - & 90-100 flow 8/ & Stock 8 \\
\hline Norway 8/ & - & - & - & - & - & - & - \\
\hline Russia & Case-by-case & - & - & - & - & - & Stock \\
\hline Spain & HIPCs & 100 & Case-by-case & Case-by-case & Case-by-case & - & Stock \\
\hline Sweden & Case-by-case & $-3 /$ & $-3 /$ & Case-by-case (100) & - & - & Stock \\
\hline Switzerland & HIPCs & $-3 /$ & $-3 /$ & Case-by-case & Case-by-case & Case-by-case, flow & Stock \\
\hline United Kingdom & HIPCs & 100 & 100 & 100 & $10010 /$ & 100 flow $10 /$ & Stock \\
\hline United States & HIPCs & 100 & 100 & 100 & $10011 /$ & 100 flow & Stock \\
\hline
\end{tabular}

Source: Paris Club Secretariat.

Note: Columns (1) to (7) describe the additional debt relief provided following a specific methodology under bilateral initiatives and need to be read as a whole for each creditor. In column (1), "HIPCs" stands for eligible countries effectively qualifying for the HIPC process. A "100 percent" mention in the table indicates that the debt relief provided under the enhanced HIPC Initiative framework will be topped up to 100 percent through a bilateral initiative.

1/ Australia: post-cutoff date non-ODA relief to apply to debts incurred before a date to be finalized; timing details for both flow and stock relief are to be finalized. 2/ Canada: including Bangladesh. Canada has granted a moratorium of debt service as of January 2001 on all debt disbursed before end-March 1999 for 11 out of 17 HIPCs with debt service due to Canada. The debt will be written off at the completion point. The countries to be covered are: Benin, Bolivia, Cameroon, Ethiopia, Guyana, Honduras, Madagascar, Mali, Senegal, Tanzania, and Zambia.

3/ 100 percent of ODA claims have already been cancelled on HIPCs, with the exception of Myanmar's debt to Canada.

4/ Denmark provides 100 percent cancellation of ODA loans and non-ODA credits contracted and disbursed before September 27, 1999.

5/ France: cancellation of 100 percent of debt service on pre-cutoff date commercial claims on the government as they fall due starting at the decision point. Once

countries have reached their completion point debt relief on ODA claims on the government will go to a special account and will be used for specific development projects.

6/ Finland: operational decisions regarding the decision reached to provide 100 percent of debt relief are pending, and expected within next few months.

7/ Italy: cancellation of 100 percent of all debts (pre- and post-cutoff date, ODA and non-ODA) incurred before June 20, 1999 (the Cologne Summit). At decision point, cancellation of the related amounts falling due in the interim period. At completion point, cancellation of the stock of remaining debt.

8/ The Netherlands: 100 percent ODA (pre- and post-cutoff date debt will be cancelled at decision point); for non-ODA: in some particular cases (Bolivia,

Burkina Faso, Mali, Ethiopia, Nicaragua, and Tanzania), the Netherlands will write off 100 percent of the consolidated amounts on the flow at decision point; all other HIPCs will receive interim relief up to 90 percent reduction of the consolidated amounts. At completion point, all HIPC countries will receive 100 percent cancellation of the remaining stock of the pre-cutoff date debt.

9/ The Norwegian authorities have informed the staff of the Fund and the World Bank that assistance beyond the HIPC Initiative will be decided after completion point.

10/ United Kingdom: "beyond 100 percent" full write-off of all debts of HIPCs as of their decision points, and reimbursement at the decision point of any debt service

paid before the decision point.

11/ United States: 100 percent post-cutoff date non-ODA treated on debt assumed prior to June 20, 1999 (the Cologne Summit) 
Table 17. HIPC Initiative: Estimated Non-Paris Club Official Bilateral Creditors' Costs, by Creditor Country

(In millions of U.S. dollars, in $2002 \mathrm{NPV}$ terms)

\begin{tabular}{|c|c|c|c|c|c|c|c|c|c|c|c|c|c|c|}
\hline & $\begin{array}{c}\text { Total: } \\
\text { (27 countries) }\end{array}$ & Benin & Bolivia & $\begin{array}{c}\text { Burkina } \\
\text { Faso }\end{array}$ & Cameroon & Chad & $\begin{array}{l}\text { Congo, } \\
\text { Dem. } \\
\text { Rep. of }\end{array}$ & Ethiopia & The Gambia & Ghana & Guinea & Guinea-Bissau & Guyana & Honduras \\
\hline Total & 3,255 & 15 & 21 & 69 & 15 & 21 & 208 & 84 & 14 & 34 & 69 & 68 & 28 & 49 \\
\hline Algeria & 206 & - & - & 1 & - & - & - & 3 & - & - & - & 4 & - & - \\
\hline Angola & 27 & - & - & - & - & - & - & - & - & - & - & 6 & - & - \\
\hline Argentina & 4 & 2 & - & - & - & - & - & - & - & - & - & - & 1 & - \\
\hline Brazil & 7 & - & 6 & - & - & - & - & - & - & - & - & - & 2 & - \\
\hline Bulgaria & 95 & - & - & - & - & - & - & 8 & - & - & 1 & - & - & - \\
\hline Burundi & 1 & - & - & - & - & - & 1 & - & - & - & - & - & - & - \\
\hline Cameroon 1/ & 0 & - & - & - & - & 0 & - & - & - & - & - & - & - & - \\
\hline Cape Verde $1 /$ & 0 & - & - & - & - & - & - & - & - & - & - & - & - & - \\
\hline China & 285 & 5 & 9 & 2 & 5 & 4 & 26 & 8 & 3 & 9 & 9 & 1 & 4 & - \\
\hline Colombia & 4 & - & - & - & - & - & - & - & - & - & - & - & - & 4 \\
\hline Costa Rica & 416 & - & - & - & - & - & - & - & - & - & - & - & - & 5 \\
\hline Côte d'Ivoire & 11 & - & - & 10 & - & 0 & - & - & - & - & - & - & - & - \\
\hline Congo, Dem. Rep. of $1 /$ & 0 & 0 & - & - & - & - & - & - & - & - & - & - & - & - \\
\hline Cuba & 2 & - & - & - & - & - & - & - & - & - & - & 0 & - & - \\
\hline Czech Republic & 8 & 2 & - & - & - & - & - & - & - & - & - & - & - & - \\
\hline Egypt & 10 & - & - & - & - & - & 7 & - & - & - & 3 & - & - & - \\
\hline Former SFR Yugoslavia & 87 & - & - & - & - & - & 28 & 20 & - & - & 2 & - & 0 & - \\
\hline Guatemala 2/ & 396 & - & - & - & - & - & - & - & - & - & - & - & - & 5 \\
\hline Honduras & 107 & - & - & - & - & - & - & - & - & - & - & - & - & - \\
\hline Hungary & 14 & - & - & - & - & - & - & 2 & - & - & - & - & - & - \\
\hline India & 33 & - & - & - & - & - & - & - & - & 1 & - & - & 1 & - \\
\hline Iran & 57 & - & - & - & - & - & - & - & - & - & - & - & - & - \\
\hline Iraq & 89 & - & - & - & - & - & - & - & - & - & 1 & - & - & - \\
\hline Israel & 14 & - & . & - & - & 0 & 14 & - & - & - & - & - & - & - \\
\hline Kuwait & 297 & 5 & - & 16 & 6 & 5 & 31 & 4 & 1 & 12 & 18 & 14 & 7 & 7 \\
\hline
\end{tabular}


Table 17 (continued). HIPC Initiative: Estimated Non-Paris Club Official Bilateral Creditors' Costs, by Creditor Country

(In millions of U.S. dollars, in 2002 NPV terms)

\begin{tabular}{|c|c|c|c|c|c|c|c|c|c|c|c|c|c|c|}
\hline & $\begin{array}{c}\text { Total: } \\
\text { (27 countries) }\end{array}$ & Benin & Bolivia & $\begin{array}{l}\text { Burkina } \\
\text { Faso }\end{array}$ & Cameroon & Chad & $\begin{array}{l}\text { Congo, } \\
\text { Dem. } \\
\text { Rep. of }\end{array}$ & Ethiopia & The Gambia & Ghana & Guinea & Guinea-Bissau & Guyana & Honduras \\
\hline Libya & 225 & 0 & - & 4 & - & - & - & 23 & 1 & - & 4 & 1 & 6 & - \\
\hline Mexico & 56 & - & - & - & - & - & - & - & - & - & - & - & - & 10 \\
\hline Morocco & 5 & - & - & - & - & - & - & - & - & - & 3 & - & - & - \\
\hline Namibia 1/ & 0 & - & - & - & - & - & 0 & - & - & - & - & - & - & - \\
\hline Niger 1/ & 0 & 0 & - & - & - & - & - & - & - & - & - & - & - & - \\
\hline Nigeria & 2 & - & - & - & - & - & - & - & - & - & - & - & - & - \\
\hline Oman & 1 & - & - & - & - & - & - & - & - & - & - & - & - & - \\
\hline Pakistan & 4 & - & - & - & - & - & - & - & - & - & - & 2 & - & - \\
\hline People's Democratic Republic of Korea & 21 & 0 & - & - & - & - & - & 12 & - & - & 0 & - & 0 & - \\
\hline Peru & 8 & - & - & - & - & - & - & - & - & - & - & - & - & - \\
\hline Poland & 16 & - & - & - & - & - & - & 4 & - & - & - & - & - & - \\
\hline Republic of Korea & 6 & - & - & - & - & - & - & - & - & 4 & - & - & - & - \\
\hline Romania & 39 & - & - & - & - & - & - & - & - & - & 5 & - & - & - \\
\hline Rwanda & 1 & - & - & - & - & - & 0 & - & - & - & - & - & - & - \\
\hline Saudi Arabia & 190 & - & - & 7 & 3 & 3 & 15 & - & 1 & 8 & 22 & 10 & - & - \\
\hline Senegal $1 /$ & 0 & - & - & - & - & 0 & - & - & - & - & - & - & - & - \\
\hline Slovak Republic & 30 & - & - & - & - & - & - & - & - & - & - & - & - & - \\
\hline South Africa & 4 & - & - & - & - & - & - & - & - & - & - & - & - & - \\
\hline Taiwan Province of Chin $\varepsilon$ & 326 & - & 6 & 29 & - & 9 & 27 & - & 9 & - & - & 29 & - & 12 \\
\hline Tanzania & 4 & - & - & - & - & - & - & - & - & - & - & - & - & - \\
\hline Thailand 1/ & 0 & - & - & - & - & - & - & - & - & - & 0 & - & - & - \\
\hline Togo 1/ & 0 & - & - & - & - & 0 & - & - & - & - & - & - & - & - \\
\hline United Arab Emirates & 84 & - & - & - & - & - & 59 & - & - & - & - & 0 & 1 & - \\
\hline Venezuela & 62 & - & 0 & - & - & - & - & - & - & - & - & - & 5 & 5 \\
\hline Zambia 1/ & 0 & - & - & - & - & - & - & - & - & - & - & - & - & - \\
\hline Zimbabwe 1/ & 0 & - & - & - & - & - & - & - & - & - & - & - & - & - \\
\hline
\end{tabular}


Table 17 (continued). HIPC Initiative: Estimated Non-Paris Club Official Bilateral Creditors' Costs, by Creditor Country

(In millions of U.S. dollars, in 2002 NPV terms)

\begin{tabular}{|c|c|c|c|c|c|c|c|c|c|c|c|c|c|c|}
\hline & Madagascar & Malawi & Mali & Mauritania & Mozambique & Nicaragua & Niger & Rwanda & $\begin{array}{l}\text { São Tomé } \\
\text { \& Príncipe }\end{array}$ & Senegal & Sierra Leone & Tanzania & Uganda & Zambia \\
\hline Total & 79 & 16 & 60 & 138 & 269 & 1,371 & 116 & 23 & 11 & 95 & 41 & 212 & 67 & 62 \\
\hline Algeria & 14 & - & 4 & 21 & 108 & 20 & 8 & - & 0 & 2 & - & 20 & - & - \\
\hline Angola & 1 & - & - & - & 13 & - & - & - & 7 & - & - & 1 & - & - \\
\hline Argentina & - & - & - & - & - & - & - & - & - & - & - & - & - & - \\
\hline Brazil & - & - & - & - & - & - & - & - & - & - & - & - & - & - \\
\hline Bulgaria & - & - & - & - & 7 & 66 & - & - & - & - & - & 10 & - & 1 \\
\hline Burundi & - & - & - & - & - & - & - & - & - & - & - & - & 0 & - \\
\hline Cameroon 1/ & - & - & - & - & - & - & - & - & - & - & - & - & - & - \\
\hline Cape Verde 1/ & - & - & - & - & & - & - & - & 0 & - & - & - & - & - \\
\hline China & 7 & - & 20 & 19 & 6 & 3 & 5 & 4 & 2 & 15 & 30 & 42 & 12 & 36 \\
\hline Colombia & - & - & - & - & - & - & - & - & - & - & - & - & - & - \\
\hline Costa Rica & - & - & - & - & - & 411 & - & - & - & - & - & - & - & - \\
\hline Côte d'IVoire & - & - & 1 & - & - & - & - & - & - & - & - & - & - & - \\
\hline Congo, Dem. Rep. of 1/ & - & - & - & - & - & - & - & - & - & - & - & - & - & - \\
\hline Cuba & - & - & - & - & 2 & - & - & - & - & - & - & - & - & - \\
\hline Czech Republic & - & - & - & - & - & 5 & - & - & - & - & - & 1 & - & 0 \\
\hline Egypt & - & - & - & - & - & - & - & - & - & - & - & 0 & - & - \\
\hline Former SFR Yugoslavia & - & - & - & - & 1 & 4 & - & - & 1 & - & - & 20 & - & 10 \\
\hline Guatemala 2/ & - & - & - & - & - & 390 & - & - & - & - & - & - & - & - \\
\hline Honduras & - & - & - & - & - & 107 & - & - & - & - & - & - & - & - \\
\hline Hungary & - & - & - & - & 5 & 5 & - & - & - & - & - & 3 & - & - \\
\hline India & - & - & - & - & 2 & 1 & - & - & . & - & - & 9 & 8 & 10 \\
\hline Iran & . & - & - & - & - & 28 & - & - & - & - & - & 28 & - & - \\
\hline Iraq & 26 & - & 3 & 20 & 21 & - & 0 & - & - & 0 & - & 17 & 0 & 0 \\
\hline Israel & & - & & & & - & & - & - & - & - & - & - & - \\
\hline Kuwait & 4 & 1 & 7 & 29 & 21 & - & 20 & $8-$ & - & 35 & 8 & 23 & \begin{tabular}{|l|}
12 \\
\end{tabular} & - \\
\hline
\end{tabular}


Table 17 (concluded). HIPC Initiative: Estimated Non-Paris Club Official Bilateral Creditors' Costs, by Creditor Country

(In millions of U.S. dollars, in 2002 NPV terms)

\begin{tabular}{|c|c|c|c|c|c|c|c|c|c|c|c|c|c|c|}
\hline & Madagascar & Malawi & Mali & Mauritania & Mozambique & Nicaragua & Niger & Rwanda & $\begin{array}{l}\text { São Tomé } \\
\text { \& Príncipe }\end{array}$ & Senegal & Sierra Leone & Tanzania & Uganda & Zambia \\
\hline Libya & 24 & - & 1 & 12 & 36 & 63 & 11 & 0 & - & - & - & 22 & 17 & - \\
\hline Mexico & - & - & - & - & - & 46 & - & - & - & - & - & - & - & - \\
\hline Morocco & - & - & - & - & - & - & - & - & - & - & 2 & - & - & - \\
\hline Namibia 1/ & - & - & - & - & - & - & - & - & - & - & - & - & - & - \\
\hline Niger 1/ & - & - & - & - & - & - & - & - & - & - & - & - & - & - \\
\hline Nigeria & - & - & - & - & - & - & - & - & - & - & - & - & 2 & - \\
\hline Oman & - & - & - & - & - & - & - & - & - & 1 & - & - & - & - \\
\hline Pakistan & - & - & - & - & - & - & - & - & - & - & - & - & 2 & - \\
\hline People's Democratic Republic of Korea & - & - & - & - & 0 & 2 & - & - & - & - & - & 0 & 6 & - \\
\hline Peru & - & - & - & - & - & 8 & - & - & - & - & - & - & - & - \\
\hline Poland & - & - & - & - & 4 & 6 & - & - & - & - & - & 2 & - & - \\
\hline Republic of Korea & - & - & - & - & - & - & - & - & - & - & - & - & 2 & - \\
\hline Romania & - & - & - & - & 29 & - & - & - & - & - & - & 0 & - & 4 \\
\hline Rwanda & - & - & - & - & - & - & - & - & - & - & - & - & 1 & - \\
\hline Saudi Arabia & 2 & - & 18 & 34 & - & - & 23 & 9 & - & 24 & 1 & 8 & 3 & 0 \\
\hline Senegal 1/ & - & - & - & - & - & - & - & - & - & - & - & - & - & - \\
\hline Slovak Republic & - & - & - & - & 9 & 21 & - & - & - & - & - & - & - & -7 \\
\hline South Africa & - & - & - & - & 4 & - & - & - & - & - & - & - & - & - \\
\hline Taiwan Province of Chin $\varepsilon$ & - & 15 & - & - & - & 131 & 46 & - & - & 13 & - & - & - & - \\
\hline Tanzania & - & - & - & - & - & - & - & - & - & - & - & - & 4 & - \\
\hline Thailand $1 /$ & - & - & - & - & - & - & - & - & - & - & - & - & - & - \\
\hline Togo 1/ & - & - & - & - & - & - & - & - & - & - & - & - & - & - \\
\hline United Arab Emirates & 1 & - & 6 & 4 & - & - & 2 & 1 & - & 4 & - & 6 & 0 & - \\
\hline Venezuela & - & - & - & - & - & 52 & - & - & - & - & - & - & - & - \\
\hline Zambia 1/ & - & - & - & - & - & - & - & - & - & - & - & 0 & - & - \\
\hline Zimbabwe 1/ & - & - & - & - & - & - & - & - & - & - & - & 0 & - & - \\
\hline
\end{tabular}

CInternational Monetary Fund. Not for Redistribution 
Table 18. HIPC Initiative: Delivery of Assistance by Non-Paris Club Creditors

Status as of June 2003

(In millions of U.S. dollars, in $2002 \mathrm{NPV}$ terms)

\begin{tabular}{|c|c|c|}
\hline Creditor country & Total costs & $\begin{array}{c}\text { Percent of total costs } \\
\text { (In percent) }\end{array}$ \\
\hline \multicolumn{3}{|l|}{ I. Delivered debt relief on all claims on HIPCs: } \\
\hline Brazil & 7.2 & 0.2 \\
\hline South Africa & 4.3 & 0.1 \\
\hline Argentina & 3.8 & 0.1 \\
\hline Tanzania & 3.5 & 0.1 \\
\hline Total & 18.9 & 0.6 \\
\hline \multicolumn{3}{|c|}{ II. Agreed to deliver debt relief on all claims on HIPCs: } \\
\hline Libya & 224.5 & 6.9 \\
\hline Honduras & 107.2 & 3.3 \\
\hline India & 33.1 & 1.0 \\
\hline Hungary & 14.4 & 0.4 \\
\hline Côte d'Ivoire & 10.9 & 0.3 \\
\hline Egypt & 10.5 & 0.3 \\
\hline Morocco & 5.2 & 0.2 \\
\hline Republic of Korea & 5.9 & 0.2 \\
\hline Pakistan & 4.1 & 0.1 \\
\hline Total & 415.8 & 12.8 \\
\hline \multicolumn{3}{|c|}{ III. Delivered or agreed to deliver debt relief on some but not all claims on HIPCs: } \\
\hline Costa Rica & 415.7 & 12.8 \\
\hline Guatemala 2/ & 395.8 & 12.2 \\
\hline Kuwait & 297.1 & 9.1 \\
\hline China & 285.0 & 8.8 \\
\hline Algeria & 205.6 & 6.3 \\
\hline Saudi Arabia & 189.5 & 6.3 \\
\hline Bulgaria & 95.0 & 5.8 \\
\hline United Arab Emirates & 84.5 & 2.6 \\
\hline Venezuela & 61.6 & 2.6 \\
\hline Mexico & 56.0 & 1.7 \\
\hline Slovak Republic & 29.9 & 0.9 \\
\hline Poland & 16.5 & 0.5 \\
\hline Czech Republic & 7.6 & 0.2 \\
\hline Cuba & 2.0 & 0.0 \\
\hline Total & $2,141.8$ & 65.8 \\
\hline \multicolumn{3}{|l|}{ IV. Not yet agreed to deliver HIPC relief: } \\
\hline Taiwan Province of China & 326.1 & 10.0 \\
\hline Iraq & 88.7 & 2.7 \\
\hline Former SFR Yugoslavia & 87.2 & 2.7 \\
\hline Iran & 56.7 & 1.7 \\
\hline Romania & 38.6 & 1.2 \\
\hline Angola & 27.0 & 0.8 \\
\hline People's Democratic Republic of Korea & 20.6 & 0.6 \\
\hline Israel & 13.7 & 0.4 \\
\hline Peru & 8.3 & 0.3 \\
\hline Colombia & 4.0 & 0.1 \\
\hline Nigeria & 1.8 & 0.1 \\
\hline Oman & 1.3 & 0.0 \\
\hline Burundi & 1.2 & 0.0 \\
\hline Rwanda & 0.8 & 0.0 \\
\hline Namibia 1/ & 0.5 & 0.0 \\
\hline Thailand 1/ & 0.5 & 0.0 \\
\hline Congo, Dem. Rep. of 1/ & 0.3 & 0.0 \\
\hline Niger $1 /$ & 0.3 & 0.0 \\
\hline Cape Verde 1/ & 0.2 & 0.0 \\
\hline Zambia 1/ & 0.2 & 0.0 \\
\hline Zimbabwe 1/ & 0.1 & 0.0 \\
\hline Cameroon 1/ & 0.0 & 0.0 \\
\hline Togo 1/ & 0.0 & 0.0 \\
\hline Senegal 1/ & 0.0 & 0.0 \\
\hline Total & 678.2 & 20.8 \\
\hline Grand Total $(I+I I+I I I+I V)$ & $3,254.7$ & 100.0 \\
\hline
\end{tabular}

Sources: HIPC country documents, country authorities; and IMF staff estimates.

1/ Total claims are less than $\$ 0.5$ million.

2/ Guatemala's claims on Nicaragua were taken over by Spain in a debt swap, and Spain has agreed to provide HIPC relief to Nicaragua on those claims.

\section{CInternational Monetary Fund. Not for Redistribution}

